\title{
DANOS MECÂNICOS PÓS-COLHEITA EM PÊSSEGO FRESCO
}

\author{
ANITA DE SOUZA DIAS GUTIERREZ \\ Engenheiro Agrônomo
}

Orientador: Prof. Dr. ANGELO PEDRO JACOMINO

Tese apresentada à Escola Superior de Agricultura "Luiz de Queiroz", Universidade de São Paulo, para obtenção do título de Doutor em Agronomia, Área de Concentração: Fitotecnia.

P I R A C I C A B A

Estado de São Paulo - Brasil

Abril - 2005 


\section{ERRATA}

GUTIERREZ, A.S.D. Danos mecânicos pós-colheita em pêssego fresco. Piracicaba, 2005. 123p. Tese (Doutorado) - Escola Superior de Agricultura "Luiz de Queiroz", Universidade de São Paulo.

$\begin{array}{cll}\text { Página } & \text { Linha } & \begin{array}{l}\text { Onde se lê } \\ \text { xi }\end{array} \\ 27 & 06 & \text { "Luis de Queiroz" } \\ 28 & 05 & \begin{array}{l}\text { Beauty } \\ \text { A maioria }(39,78 \%) \\ \text { de oferta }\end{array}\end{array}$

\begin{tabular}{|c|c|c|}
\hline 28 & 22 & 1749 \\
\hline 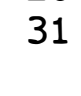 & 16 & $\begin{array}{l}\text { Entre as principais causas de } \ldots \\
\text { e pela classificação }(13 \%) \text {. }\end{array}$ \\
\hline 33 & 13 & $\begin{array}{l}\text { outubro de } 2001 \text { a janeiro de } \\
2002 \text { e }\end{array}$ \\
\hline 42 & Figura 1 & Danos fisiológicos (bióticos) \\
\hline & & danos pós-colheita \\
\hline 52 & 13 & $\begin{array}{l}\text { das caixas amostradas e } \\
11,38 \% \text { dos frutos examinados. }\end{array}$ \\
\hline 0 & 13 & a produção de etileno, \\
\hline U & 21 & e comportamento...etileno \\
\hline 71 & 09 & etileno, \\
\hline 71 & 24 & and ethylene production \\
\hline 72 & 04 & first production of ethylene \\
\hline 72 & 08 & ethylene, \\
\hline 73 & 10 & e maior produção de etileno \\
\hline 78 & 10 & , liberação de etileno...e da \\
\hline 9 & 27 & A produção....anteriores. \\
\hline 83 & Tabela 20 & $S$ \\
\hline 85 & 19 & Tókio \\
\hline 85 & 22 & "radio" \\
\hline 87 & 10 & (Tabelas 20 e 26 ) \\
\hline 87 & 12 & Tabela 26 \\
\hline 87 & 21 & $\begin{array}{l}2 \text { dias, e sua diminuição...para } \\
15 \mathrm{~cm} \text {. }\end{array}$ \\
\hline 88 & 02 & , a produção de etileno \\
\hline & 07 & , na produção de etileno \\
\hline & 10 & $\begin{array}{l}\text { e quando...das leituras } \\
\text { anteriores. }\end{array}$ \\
\hline 89 & & A variabilidade....impacto. \\
\hline & Figura 11 & Figura 11 \\
\hline & & , a produçao de etileno \\
\hline & 09 & e pela produção inicial de etileno \\
\hline & & Tabela 28 \\
\hline & Tabela 28 & Tabela 28 \\
\hline & & $\begin{array}{l}\text { A ocorrência de anomalias...e } \\
\text { maior firmeza de polpa. }\end{array}$ \\
\hline
\end{tabular}

Leia-se

"Luiz de Queiroz"

Biuti

$39,78 \%$ dos atacadistas

ofereceram pêssego durante um único mês

$1749 \mathrm{~kg}$

Danos fisiológicos (abióticos) danos pós-colheita em pêssegos das caixas e $19,90 \%$ dos frutos. e da

*

Tukey

"ratio"

(Tabela 20)

Excluir Tabela 26

2 dias.
Excluir Figura 11

Tabela 29

Excluir Tabela 28 
Dados Internacionais de Catalogação na Publicação (CIP) DIVISĀO DE BIBLIOTECA E DOCUMENTAÇĀO - ESALO/USP

Gutierrez, Anita de Souza Dias

Danos mecânicos pós-colheita em pêssego fresco / Anita de Souza Dias Gutierrez. - Piracicaba, 2005.

123 p. : il.

Tese (doutorado) - - Escola Superior de Agricultura Luiz de Queiroz, 2005.

Bibliografia.

1. Dano mecânico 2. Mercado atacadista 3. Pêssego 4. Pós-colheita 5. Qualidade dos alimentos I. Título

CDD 634.25

Termitida a copla total ou parcial deste documento, desde que citada a fonte- 0 autort 


\section{AGRADECIMENTOS}

Aos produtores Renato Leme e Norival Gallo.

À equipe do projeto "Quantificação de perdas de frutos em póscolheita e difusão de tecnologia para identificação de suas causas e seu controle" coordenado pela professora Lílian Amorim.

Ao professor Angelo Pedro Jacomino, meu orientador e à equipe do Laboratório de Pós-Colheita.

Ao professor Marcos David Ferreira da FEAGRI - UNICAMP.

À pesquisadora Ana Beatriz C. Czermainski da EMBRAPA

À equipe do Centro de Qualidade em Horticultura e à CEAGESP. 


\section{SUMÁRIO}

LISTA DE FIGURAS

Página

LISTA DE TABELAS.

LISTA DE ABREVIATURAS E SÍMBOLOS.

viii

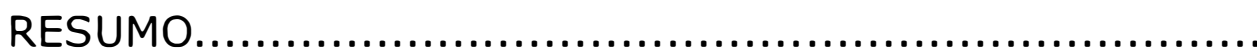

SUMMARY

1 INTRODUÇÃO.

2 REVISÃO DE LITERATURA

3 O PÊSSEGO NO ENTREPOSTO TERMINAL DE SÃO PAULO

DA CEAGESP.

Resumo.

Summary

3.1 Introdução

3.2 Material e Métodos.

3.3 Resultados e Discussão..........................................

3.4 Conclusões.

4 DANOS MECÂNICOS PÓS-COLHEITA DE PÊSSEGOS NO MERCADO ATACADISTA.

Resumo

Summary.

4.1 Introdução.

4.2 Material e Métodos.

4.3 Resultados e Discussão.

4.4 Conclusões.

5 OCORRÊNCIA DE DANOS MECÂNICOS PÓS-COLHEITA NO PÊSSEGO 'AURORA' - DA PLANTA AO LEILÃO DE COMERCIALIZAÇÃO.

Resumo.

Summary....

5.1 Introdução.

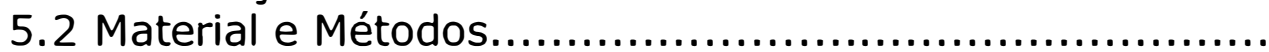

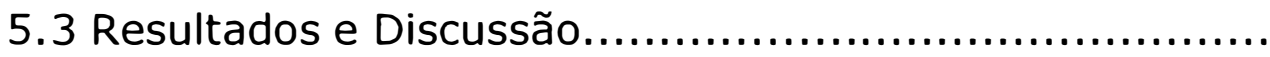


6 EFEITO DO IMPACTO NA QUALIDADE E NO

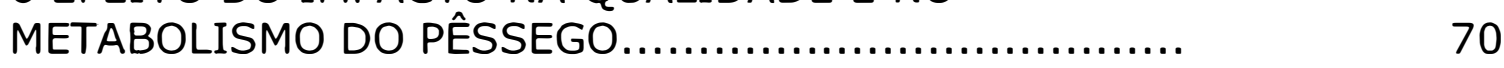

Resumo....................................................... 70

Summary.................................................. 71

6.1 Introdução..............................................

6.2 Material e Métodos........................................... 74

6.3 Resultados e Discussão.................................. 50

6.4 Conclusões.............................................. 95

7 A PERDA DA MASSA FRESCA DO PÊSSEGO NA PÓSCOLHEITA EM DIFERENTES ELOS DA CADEIA DE

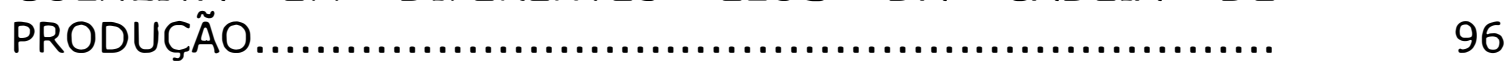

Resumo....................................................... 96

Summary................................................... 97

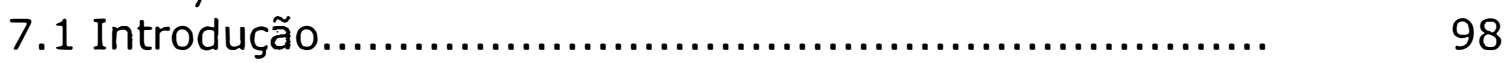

7.2 Material e Métodos......................................... 100

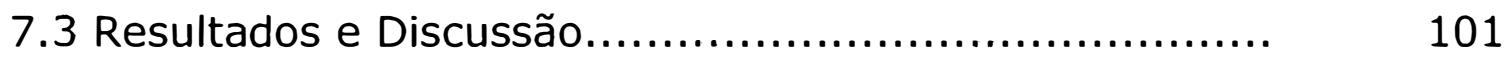

7.4 Conclusões............................................... 105

8 CONCLUSÕES GERAIS...................................... 106

ANEXOS .................................................. 108

REFERÊNCIAS BIBLIOGRÁFICAS .............................. 116 


\section{LISTA DE FIGURAS}

1 Danos mecânicos, fisiológicos e de origem biótica póscolheita de pêssego..............................................

Página

2 Levantamento dos danos pós-colheita de pêssego no mercado atacadista......

3 Porcentagem de danos pós-colheita (bióticos e mecânicos) em pêssegos, na safra 2002-2003, avaliados no ETSP da CEAGESP....

4 Porcentagem de danos pós-colheita (bióticos e mecânicos) em pêssegos 'Aurora' na safra 2002-2003 avaliados no ETSP da CEAGESP................................

5 . Pontos de localização do dano no fruto.......................

6 Prática do produtor em cada ponto de coleta.................

7 Danos pós-colheita em pêssegos..............................

8 Pêssegos 'Aurora' antes e durante a aplicação do impacto. 'Aurora' antes e... durante a aplicacão do

9 Força de impacto registrada pela esfera instrumentada submetida a quedas de diferentes alturas sobre uma placa de aço (Ferreira, 2004) ................................

10 Efeito da altura do impacto, na perda percentual de massa fresca do pêssego 'Aurora', após 2 dias e 4 dias.

11 Produção de etileno em função da altura de

12 Taxa de respiração, medida através da produção de $\mathrm{CO}_{2}$, em $\mathrm{mL} \mathrm{CO}_{2} / \mathrm{Kg}^{-1} \mathrm{~h}^{-1}$, em função da altura de impacto $(\mathrm{cm})$, em cada leitura....................

Perda percentual da massa fresca no ensaio de
avaliação de metabolismo, em diferentes alturas de impacto.... 
14 Intensidade da perda de massa fresca por dia e por ponto de coleta, no $1^{\circ}$ dia e $4^{\circ}$ dia depois da colheita, do pêssego 'Aurora', da planta à saída do barracão de classificação.... 


\section{LISTA DE TABELAS}

1 Sazonalidade do pêssego na safra 2003-2004, no Entreposto Terminal de São Paulo........................ 26

2 Participação dos principais municípios de São Paulo, fornecedores de pêssego no ETSP, na safra 20032004, no total fornecido pelo Brasil e pelo Estado de São Paulo.

Página

3 Volume das principais variedades de pêssego comercializadas no Entreposto Terminal de São Paulo

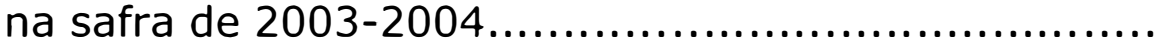

$4 \quad$ Número de meses de oferta por variedade de pêssego na safra 2003-2004, no Entreposto Terminal de São Paulo.......................................................

5 Número de meses de permanência na comercialização de pêssego por atacadista na safra 2003-2004, no Entreposto Terminal de São Paulo

6 Porcentagem de frutos amassados e com podridão em relação ao total de anomalias registradas de 1998 a 2001, em pêssegos avaliados no ETSP.

7 Porcentagem de frutos amassados e com podridão em relação ao total de anomalias registradas de 1998 a 2001, em pêssegos 'Aurora', avaliados no ETSP..........

8 Datas de amostragem, número de caixas vistoriadas e número de pêssego examinados em cada avaliação nas safras 2002-2003 no ETSP da CEAGESP

9 Representatividade (porcentagem) de cada cultivar de pêssego no total de amostras analisadas nas safras 2001-2002 e 2002-2003 no ETSP da CEAGESP ...........

10 Porcentagem de pêssego com danos mecânicos, bióticos e totais no ETSP..................................... 
11 Porcentagem de danos mecânicos e número de amostras avaliadas por produtor entre os seis maiores produtores avaliados.......................................

12 Proporção de amostras (caixas de pêssego) com danos bióticos e mecânicos na safra 2002-2003 ................

13 Datas de amostragem, número de caixas vistoriadas e número de pêssego 'Aurora' examinados em cada avaliação na safra 2002-2003 no ETSP da CEAGESP....................................................

14 Porcentagem de frutos de pêssego 'Aurora' com danos totais, bióticos e mecânicos na safra 2002-2003 ........

15 Porcentagem de anomalias em pêssegos 'Aurora' em função do ponto de coleta. Resultados expressos em porcentagem do número de frutos com anomalia no número total de frutos avaliados.

16 Porcentagem de pêssegos 'Aurora' com danos mecânicos - batida, prensados e com lesão aberta em cada ponto de coleta....................................

17 Porcentagem total de danos mecânicos pós-colheita em pêssego 'Aurora' em função do local do fruto ........

18 Porcentagem de ocorrência do dano, em função da localização no fruto, em frutos batidos, prensados e com lesão aberta............................................

19 Caracterização físico-química do pêssego recémcolhido......................................................

20 Significância da estatística $F$, para os efeitos considerados no modelo de análise de variância e coeficiente de variação, no ensaio de avaliação de impacto sobre a qualidade do fruto: teor de sólidos solúveis, acidez, "ratio" e firmeza da polpa.................

21 Efeito da altura do impacto no teor de sólidos solúveis, na acidez e no "ratio" do fruto após 2 dias e 4 dias na polpa de pêssegos 'Aurora' ..................................

22 Efeito da altura de impacto na acidez titulável média do pêssego 'Aurora'.

23 Efeito da altura do impacto na firmeza da polpa de pêssegos 'Aurora'.

24 Significância da estatística $F$, para os efeitos considerados no modelo de análise de variância e coeficiente de variação, no ensaio de avaliação de impacto sobre a qualidade do fruto: cor de fundo ....... 
25 Influência da altura de impacto na cor de fundo do pêssego 'Aurora' .........................................

26 Influência da época de avaliação na cor de fundo do pêssego 'Aurora' ...........................................

27 Análise de variância para o ensaio de avaliação do efeito do impacto sobre o metabolismo do fruto .........

28 Significância da estatística $F$, para os pontos de coleta do pêssego 'Aurora', da planta à saída do barracão de classificação.

29 Perda acumulada de massa fresca total do pêssego 'Aurora', em função do ponto de coleta, em duas épocas, $1^{\circ}$ dia e $4^{\circ}$ dia 


\section{LISTA DE ABREVIATURAS E SÍMBOLOS}

CEAGESP... Companhia de Entrepostos e Armazéns Gerais de São Paulo

CQH.......... Centro de Qualidade em Horticultura

ETSP......... Entreposto Terminal de São Paulo

ESALQ....... Escola Superior de Agricultura "Luis de Queiroz"

FEAGRI..... Faculdade de Engenharia Agrícola

IBGE......... Instituto Brasileiro de Geografia e Estatística

IEA......... Instituto de Economia Agrícola de São Paulo

UNICAMP... Universidade Estadual de Campinas

SIM.......... Sistema de Informação de Mercado 


\title{
DANOS MECÂNICOS PóS-COLHEITA EM PÊSSEGO FRESCO
}

\author{
Autora: ANITA DE SOUZA DIAS GUTIERREZ \\ Orientador: Prof. Dr. ANGELO PEDRO JACOMINO
}

\section{RESUMO}

A ocorrência de distúrbios pós-colheita em pêssegos frescos é uma importante causa de desvalorização e rejeição do produto na comercialização. Na safra 2002-2003 foi feita a quantificação e a caracterização dos danos mecânicos pós-colheita do pêssego fresco, no momento da sua comercialização, no mercado atacadista - Entreposto Terminal de São Paulo da CEAGESP. A ocorrência dos danos pós-colheita totais variou de 5,50\% a 45,40\% e mostrou correlação $(r=0,52)$ entre a freqüência de danos mecânicos e a de danos bióticos. Houve uma variação de 0,13\% a 19,90\% na ocorrência de frutos com danos mecânicos e de 4,92\% a 11,38\% de frutos com danos bióticos. Os danos mecânicos foram, em média, mais elevados que os danos bióticos e apresentaram diferença significativa entre origens (produtor). Na safra 2003-2004, foram coletados frutos (pêssego 'Aurora') com anomalias, em diferentes 
pontos da cadeia de produção: na planta, na sacola da colhedora, na entrada da máquina de classificação, na saída da máquina de classificação e no leilão de comercialização. A ocorrência total de anomalias cresceu com o manuseio do fruto, da colheita na planta ao leilão de comercialização. Os maiores registros dos danos mecânicos pós-colheita aconteceram na saída do barracão de classificação e na sacola da colhedora. A batida foi a anomalia de maior ocorrência e de maior crescimento com a intensidade do manuseio. Na mesma safra foi feita uma avaliação em laboratório do efeito do impacto em diferentes alturas sobre a qualidade e o metabolismo do pêssego 'Aurora' e em outro ensaio uma avaliação do potencial da perda de massa fresca como medida da intensidade de manuseio na póscolheita do pêssego. Não houve efeito visível do impacto nos pêssegos submetidos a quedas sobre uma chapa de aço, das alturas de 5,10 e $15 \mathrm{~cm}$. O efeito do impacto foi registrado pela perda de massa fresca, a intensidade de respiração e a produção inicial de etileno. A diferença observada ocorreu entre as alturas de impacto 5 $\mathrm{cm}$ e $15 \mathrm{~cm}$. A avaliação da perda de massa fresca do fruto como medida da intensidade do manuseio na pós-colheita do pêssego, mostrou que a perda de massa fresca cresce com o tempo e com o manuseio do fruto. A perda de massa fresca foi mais intensa na máquina de classificação.

PALAVRAS-ChaVe: Prunus persica L., dano por impacto, mercado atacadista, qualidade. 


\title{
FRESH PEACH POSTHARVEST MECHANICAL DAMAGES
}

\author{
Author: ANITA DE SOUZA DIAS GUTIERREZ \\ Adviser: Prof. Dr. ANGELO PEDRO JACOMINO
}

\section{SUMMARY}

The postharvest disorders are an important reason for rejection and depreciation of fresh market peach. Fresh market peach, 2001-2002 and 2002-2003 harvests, was inspected at São Paulo's Fruit and Vegetable Terminal Market, ETSP/CEAGESP for mechanical disorders. The total postharvest disorders have ranged from $5,5 \%$ to $45,4 \%$, the mechanical disorders from $0,13 \%$ to $19,90 \%$ and the biotic diisorders from $4,92 \%$ to $11,38 \%$. The mechanical damages were more frequent then the biotic damages. There was a significant difference between different origins (growers) and correlation $(r=0,52)$ between mechanical and biotic damages. The postharvest mechanical disorders (2003-2004 harvest) were assessed at several points of production: plant, harvester bag, before packinghouse mechanical selection, after packinghouse mechanical selection and at public auction house. The disorders have increased 
from plant to public auction house. The biotic and mechanical disorders were bigger at the end of packinghouse mechanical selection and at harvester bag. The bruise damage was the most frequent at all points and its occurrence has grown with handling intensity. A laboratory test was made to measure the quality and metabolic effects of impact in fresh market peach 'Aurora' (20032004 harvest), at harvest opening. The impact did not show visible bruise damage in all tested drop heights: 5, 10 and $15 \mathrm{~cm}$. The impact effect was registered by the variables: fresh matter loss, respiration intensity $\left(\mathrm{CO}_{2}\right.$ production) and initial production of ethylene, between 5 and $15 \mathrm{~cm}$ drop height. Other study has measured the fresh matter loss at several points of production. The fresh matter loss was bigger at packinghouse mechanical selection. The fresh matter loss has increased with handling intensity and time. KEY WORDS: Prunus persica L., impact damage, terminal market, bruise injury, quality. 


\section{INTRODUÇÃO}

Os estudos realizados por Sato (2001), mostram que o Brasil não produz a quantidade de pêssego suficiente para o seu consumo interno, seja para a indústria ou para o consumo in natura. Em 1999, foram importadas 16.887 toneladas de pêssego em calda, no valor FOB total de US $\$ 12,8$ milhões e 3.039 toneladas de pêssegos frescos no valor de US $\$ 2,4$ milhões. A produção nacional de pêssego atingiu 112 mil toneladas em 1998. O Rio Grande do Sul respondeu por $55 \%$ do total, com 62 mil toneladas por ano. A produção do Rio Grande do Sul destina-se quase que totalmente à indústria de conservas, para a fabricação de pêssego em calda.

A produção e a área plantada de pêssego em São Paulo aumentaram nos últimos anos. Os dados citados por Sato (2001), mostram uma produção paulista de 16.687 toneladas em 1.996 e de 32.998 toneladas em 2.002 (IEA, 2004). O período de oferta de pêssego fresco se prolongou, a partir dos anos 70, em virtude da introdução de variedades mais adequadas ao clima mais quente, que permitiu o aumento do plantio nos estados de São Paulo e do Paraná. O sistema de produção, predominantemente artesanal, sofreu mudanças importantes, com a entrada de produtores maiores e mais tecnificados, concentrados na região agrícola de Avaré, estado de São Paulo. 
O valor de venda do pêssego é função da época de oferta, da variedade, da embalagem, do tamanho e aparência do fruto e da ocorrência de danos, que afetam a qualidade do fruto. Os pêssegos são frutos delicados, bastante sensíveis a danos póscolheita. A ocorrência de distúrbios pós-colheita em pêssegos frescos é uma importante causa de sua desvalorização ou rejeição na comercialização.

O presente trabalho visa a compreensão da ocorrência dos danos mecânicos pós-colheita do pêssego fresco, base para o estabelecimento de estratégias de prevenção de danos. Para isto é preciso caracterizar a comercialização do pêssego fresco; quantificar e caracterizar os danos mecânicos pós-colheita do pêssego fresco; identificar os pontos críticos de ocorrência de danos na cadeia de produção e avaliar o efeito do impacto na qualidade e no metabolismo do fruto. 


\section{REVISÃO DE LITERATURA}

O Dicionário Houaiss da Língua Portuguesa apresenta 17 diferentes conceitos para qualidade (Instituto Antonio Houaiss de Lexicografia, 2.001). Aqui estão os mais apropriados ao nosso estudo: propriedade que determina a natureza de um ser ou coisa; característica superior ou atributo definitivo que faz alguém ou algo sobressair em relação aos outros. "Qualidade é o grau de excelência do produto ou a sua adequação a um determinado uso" (Abott, 1999).

$O$ estudo e o controle de qualidade exigem a medida dos atributos de qualidade. A qualidade das frutas e hortaliças frescas engloba desde seus atributos sensoriais, seus valores nutritivos, seus constituintes químicos e suas propriedades funcionais até os seus defeitos (Abott, 1.999).

Na elaboração dos regulamentos técnicos de identidade e qualidade de cada fruta ou hortaliça consumida fresca, consideramse na caracterização da qualidade os defeitos e a garantia mínima de atributos sensoriais. É uma tarefa extremamente complexa, devido à perecibilidade característica das frutas e hortaliças frescas; à necessidade de avaliação da qualidade em diferentes pontos da cadeia: produção, embalador, atacadista, varejista, consumidor; à transformação natural do produto durante o processo de distribuição 
e comercialização e ao desenvolvimento dos danos no fruto, que ocorrem ao longo do processo de distribuição e comercialização. O regulamento técnico de identidade e qualidade do pêssego fresco, proposto por Gutierrez (2004), estabelece alguns conceitos, que serão utilizados neste trabalho. Defeito ou dano ou anomalia - toda e qualquer alteração do fruto causada por fatores de natureza fisiológica ou mecânica e por agentes diversos, que comprometam a qualidade do fruto. Podridão -dano patológico visível por decomposição, desintegração ou fermentação dos tecidos. Dano profundo ou lesão aberta - qualquer lesão, não importando a sua causa, que rompa a epiderme, expondo a polpa do fruto. Amassado ou batida - alteração da polpa sem ruptura da epiderme, com escurecimento enzimático interno e deformação, visíveis externamente. Dano cicatrizado - todas as lesões que embora tenham rompido a epiderme, estão cicatrizadas e não expõem a polpa, mas alteram a textura da polpa e o formato da superfície do fruto. Defeito de casca - alteração na coloração, na textura normal da epiderme do fruto e descoloração.

Estima-se que 30 a $40 \%$ das frutas e vegetais sofrem algum tipo de dano, da colheita ao mercado (Peleg \& Hinga, 1986). O desenvolvimento de podridão, o dano mais grave, inviabiliza o consumo da unidade do produto e até a venda do lote, em virtude do seu potencial de disseminação para os outros frutos. Os agentes causais associados à podridão de órgãos de reserva são fungos e bactérias que ocorrem no ar e no solo (Bedendo, citado por Zagory, 1999). As frutas e hortaliças frescas estão cobertas por uma mistura complexa e equilibrada de bactérias, fungos e leveduras, característica de cada produto. O desenvolvimento da população microbiana, é determinado por fatores que enfraquecem ou danificam 
os tecidos da planta. Os patógenos, com ação pectinolítica, são, em geral, oportunistas e só invadem efetivamente a planta através de tecidos feridos ou senescentes. Tecidos saudáveis intactos constituem um substrato pobre para o crescimento microbiano. As condições que causam danos ao produto são as mesmas que favorecem o crescimento e o estabelecimento de altas populações microbianas (Zagory, 1999). Pode se afirmar que o dano é responsável pela alta população de microorganismos e não que a alta população de microorganismos é responsável pelo dano. A redução de dano e a preservação da integridade fisiológica das frutas e hortaliças frescas garantem uma baixa população de microorganismos e a diminuição da integridade leva a uma alta população de microorganismos (Bolin et al., 1997).

Os pêssegos são reconhecidamente frutos delicados, bastante sensíveis a danos pós-colheita. Um estudo realizado por Cappellini \& Ceponis (1984) nos Estados Unidos da América, mostrou que os danos pós-colheita de pêssego fresco variaram de 2,3\% a $12,3 \%$ no mercado atacadista e de $4,5 \%$ a $5,8 \%$ de frutos doentes no mercado varejista. Em 2610 cargas de pêssego inspecionadas, no mercado atacadista de Nova Iorque, foram constatadas 2268 com frutos com abrasão e prensados, 87\% do total (Ceponis et al., 1987). Foram encontrados outros danos mecânicos em mais de 1500 cargas. O estudo não apresentou a porcentagem total de danos por carga nem a porcentagem de cargas com pelo menos um tipo de dano. Os dados se referem à porcentagem de carregamentos com determinado dano, individualmente. Sabe-se que em 87 \% dos carregamentos amostrados houve abrasão, em 25\% podridão de Rhizopus, em 2,5\%, podridão parda e assim por diante, mas é impossível saber se houve 
algum carregamento sem dano. A freqüência mínima de carregamentos com pelo menos um fruto danificado foi de $87 \%$.

Mohsenin (1986) definiu danos mecânicos como deformações plásticas, rupturas superficiais e destruição dos tecidos vegetais, provocadas por forças externas e que levam a modificações físicas e alterações fisiológicas, químicas, bioquímicas na cor, aroma, sabor e firmeza de polpa. Os danos mecânicos podem ser agrupados em danos por compressão, por impacto e por corte. O dano por impacto é causado pela colisão do fruto contra superfícies sólidas ou outros frutos durante as etapas de colheita, manuseio e transporte. 0 dano mecânico por compressão é causado pela imposição de uma pressão variável contra a superfície externa do fruto, quer seja por um fruto adjacente ou pela própria parede da embalagem em que está acondicionado o fruto. O dano por corte é atribuído à colisão da superfície do fruto contra outra superfície muito menor, ocasionando a ruptura da epiderme, ou pela imposição de uma pressão sobre o fruto contra superfícies também desiguais, como as arestas de uma embalagem (Mattiuz, 2002).

O dano por impacto em uma fruta, quando a fruta atinge uma superfície, está relacionado à diminuição de sua velocidade de movimentação e ao grau de deformação da fruta, e é função da massa da fruta, da velocidade do impacto, das propriedades da superfície de impacto e das propriedades dos tecidos da fruta (O'Brien et al., 1983). A severidade do dano depende da altura do impacto, da energia do impacto, do número de impactos, do tipo da superfície de impacto, e do tamanho e maturidade do fruto (Chen \& Yazdani, 1991). Segundo Sitkei, citado por Ogut et al. (1999) a sensibilidade ao dano varia com o estado físico e biológico do fruto 
(temperatura, conteúdo de água, estádio de crescimento e maturação) e com fatores ligados ao manuseio e transporte. As propriedades mecânicas dos frutos são muito influenciadas pela sua temperatura e conseqüentemente também a sua sensibilidade ao dano. A turgidez das células e a sua elasticidade variam com a temperatura.

O tamanho e a localização dos danos dependem da estrutura dos tecidos internos do fruto (Kunze et al., 1957). O tecido do pêssego é denso e suculento e apresenta baixo volume de espaço intersticial cheio de ar, o que causa suscetibilidade a danos profundos não visíveis na epiderme (Maness, 1992) e alta capacidade de absorção de impacto, conforme mostram Crisosto et al. (2000), ao comparar o impacto da esfera instrumentada em diferentes superfícies e em pêssego, numa queda de $600 \mathrm{~mm}$ de altura - o pêssego consegue absorver mais impacto que uma superfície acolchoada de espuma de 5,40 centímetros de espessura.

A transpiração é o principal processo envolvido na perda de matéria fresca (massa das frutas após a colheita). Ela é conseqüência do déficit de pressão do vapor (DPV) e do coeficiente de transpiração. O DPV é a diferença entre a pressão do vapor dos espaços intercelulares dos tecidos da fruta e a pressão do vapor do ar circundante a ela. $O$ coeficiente de transpiração é a perda de umidade de uma fruta em uma unidade de tempo por déficit de pressão de vapor. Quanto maior o DPV entre a frutal e o ar circundante maior será a perda de água pela transpiração. O DPV é dependente da temperatura e da umidade relativa do ar (Kluge et al., 2002). Em condições semelhantes de temperatura e umidade relativa do ar 
podemos considerar que o coeficiente de transpiração dependerá da permeabilidade da fruta à perda de água.

A permeabilidade à perda de água para a atmosfera varia com a espécie, o cultivar e com as práticas de produção e manejo na colheita e pós-colheita da fruta. O efeito do manejo na permeabilidade da fruta é pouco estudado (Fresh Technologies, 2004) e a estratégia de prevenção das micro-rachaduras na cutícula da fruta é imprescindível, pois as rachaduras enfraquecem as propriedades da cutícula. A intensidade e a velocidade da perda de massa fresca são medidas que podem retratar os efeitos do manuseio em cada ponto da cadeia.

A esfera instrumentada é um sensor portátil desenvolvido pelo Departamento de Agricultura dos Estados Unidos na década de 80, em conjunto com a Michigan State University, capaz de registrar a magnitude dos impactos ocorridos durante as operações de manuseio e é comercializado pela Techmark. E. Lansing. MI (Techmark, 2004). A severidade dos danos por impacto depende da força (aceleração máxima) e da duração do impacto. A medida da força não é suficiente para predizer a severidade do dano por impacto: impactos de duração menor são mais prejudiciais que de duração mais longa, na mesma força. A duração de tempo do impacto depende da superfície de impacto e das características do produto. A esfera instrumentada mede a aceleração do impacto e a mudança de velocidade, para caracterizar a severidade do impacto. Vários estudos, medindo e efeito do impacto no pêssego fresco, foram feitos utilizando a esfera instrumentada. A firmeza do fruto, a cor do fruto e variação da massa fresca do pêssego, foram algumas das características estudadas. Aqui estão os mais importantes. 
Lin et al. (1994) estudaram o efeito da queda livre de frutos de pêssego de 4 cultivares, sobre uma chapa de aço e sobre outro fruto estacionário. Os mesmos estudos foram feitos com a esfera instrumentada. A avaliação do dano visível foi feita 24 horas depois do impacto. Foram também utilizadas a firmeza do fruto e a cor de fundo, como medidas de avaliação. O efeito do impacto do pêssego sobre uma chapa de aço foi avaliado em 6 alturas: 30, 50, 100, 150, 200 e 300 mm. Cada tratamento utilizou 10 pêssegos e cada pêssego foi submetido à queda em cada um dos ombros opostos. A medida do diâmetro do dano, maior área descolorida na polpa, foi feita 24 horas depois no fruto armazenado a $24^{\circ}$ C. A firmeza média dos cultivares 'Loring', 'Elberta', 'Cresthaven' e 'Jefferson' foram respectivamente 47,8, 50,0, 69,8 e 52,1 libras. Os frutos com firmeza superior às médias do seu cultivar, foram considerados duros e os com firmeza abaixo das médias como macios. Os pêssegos macios apresentaram uma incidência maior de danos que os pêssegos duros, principalmente entre as alturas de queda entre 40 e $200 \mathrm{~mm}$. O valor do a* na porção mais verde do fruto (medido na escala CIE pelo colorímetro CR-300 da Minolta), foi considerado como uma característica importante na predição do potencial de dano no pêssego. A sensibilidade ao impacto do pêssego 'Loring' apresentou uma relação direta com valor de a*, apesar de ser o cultivar menos colorido (menor valor médio de $a^{*}$ ).

A medida de firmeza do fruto é considerada, por Crisosto (1994), um excelente indicador da maturação máxima do fruto. A firmeza da polpa (Kluge et al., 2002), é função das substâncias pécticas que compõem a parede celular e que, no processo de amadurecimento, tornam-se solúveis, levando ao 
amolecimento da polpa. O amaciamento da polpa resulta da ação de enzimas como a PME (pectina metil-esterase e as poligalactunorase) (Araújo, 1998).

O trabalho de Schulte et al. (1994) utilizou superfícies de aço e acolchoada e testou diferentes alturas de queda até garantir uma probabilidade de ocorrência de dano visível de 0\% a 100\% no pêssego 'Redhaven', em 2 datas de colheita e avaliou a ocorrência de dano visível e o tamanho do dano. Foi observada uma grande variação da firmeza da polpa (medida ao lado do local do impacto e imediatamente após o impacto), e os frutos foram separados em 3 categorias de firmeza, para facilitar a análise. A primeira categoria, firme, variou de 35,6 a $53,4 \mathrm{~N}$; a segunda categoria, macia, variou de 17,8 a $26,7 \mathrm{~N}$; a terceira categoria, muito macia, de 2,2 a 13,3 N. Os frutos macios apresentaram início de dano com $50 \mathrm{~mm}$ e os firmes com $80 \mathrm{~mm}$ de altura de queda. Dois pontos do fruto foram atingidos: ombro e sutura, escolhidos por apresentarem maior sensibilidade em outro estudo de Schulte et al. (1990). Houve grande diferença de sensibilidade ao impacto entre os dois pontos do fruto, que variou com a firmeza do fruto, a data de colheita. A maior sensibilidade foi observada na sutura do fruto, muito macio, da $2^{\text {a }}$ colheita. Houve uma grande diferença de comportamento entre os frutos das 2 colheitas. Uma queda direcionada para atingir a sutura do fruto, maior que 100 $\mathrm{mm}$, em superfície de aço, teve $100 \%$ de dano no fruto macio. A mesma ocorrência para o fruto firme exigiu uma altura de queda superior a $200 \mathrm{~mm}$.

O estudo da maturidade máxima de colheita de frutas de caroço foi feito junto com a determinação do limite crítico de dano no ponto mais suscetível do fruto, calculado a partir de diferentes 
níveis de firmeza e expresso na unidade G (aceleração). O cálculo do limite crítico de dano considerou o impacto que o fruto sofre nas operações de colheita e pós-colheita. O levantamento, com a esfera instrumentada IS-100, em diferentes sistemas e máquinas de classificação mediu a aceleração, mostrou uma variação de 24 a 220 G. A operação de embalamento manual foi a responsável pelo maior valor encontrado. $O$ ponto do fruto mais sensivel ao impacto variou com o cultivar. Nos cultivares precoces, o ponto mais sensível foi o bico, nos cultivares tardios foi o ombro e em alguns cultivares foi a sutura. A suscetibilidade ao impacto foi determinada submetendo os frutos a quedas de diferentes alturas sobre o seu ponto mais sensível. Os impactos utilizados foram: 66, 185 e 245 G. O resultado mostrou que os frutos mais macios foram mais suscetíveis ao impacto que os frutos mais firmes e que impactos repetidos sobre o mesmo ponto do fruto são acumulativos. Alguns cultivares, com firmeza entre 7 e 10 libras, não mostraram sensibilidade ao impacto. Os cultivares de polpa amarela mostraram menor sensibilidade ao dano que os de polpa branca. Para entender a variação da firmeza do fruto na colheita, foram avaliados frutos em diferentes posições numa mesma árvore. Houve uma variação desordenada de firmeza e de teor de sólidos solúveis com a posição do fruto na copa. O efeito da altura da queda sobre uma superficie de borracha de $1 / 8$ polegadas aumentou com a altura para todos os cultivares. Três, dos oito cultivares testados, apresentaram mais de $40 \%$ de dano numa queda de $50 \mathrm{~mm}$ de altura. Dois, dos oito cultivares, só apresentaram probabilidade de dano maior que $20 \%$ numa altura de impacto acima de $250 \mathrm{~mm}$. (Crisosto, 1.996a) 
O estudo do limite crítico de dano para o pêssego com caroço preso para a indústria foi feito em cinco cultivares diferentes. O local mais sensivel na fruta e o efeito da mudança da posição da fruta na copa na suscetibilidade ao dano foram estudados. Frutos de diferentes estádios de maturação foram submetidos a quedas de 100, 200 e $300 \mathrm{~mm}$, equivalentes respectivamente a 240,320 e $360 \mathrm{G}(\mathrm{G}=$ $\left.9,81 \mathrm{~m} / \mathrm{s}^{2}\right)$, no ombro ou no dorso ou no bico. Foram consideradas comercialmente significativas para a indústria as áreas danificadas maiores que $100 \mathrm{~mm}^{2}$. Foi feita a avaliação inicial da qualidade dos frutos: cor, firmeza não destrutiva e firmeza da polpa no dorso, na sutura, no ombro e no bico do fruto. No suco, retirado de uma secção longitudinal do fruto, foram analisados o teor de sólidos solúveis e a acidez titulável. Depois do impacto, a firmeza da polpa foi determinada próxima aos pontos de impacto no fruto, e a visibilidade do dano foi verificada depois de 12 horas a $20^{\circ} \mathrm{C}$ e de 3 a 5 dias a $0^{\circ}$ C. A porcentagem de ocorrência de dano visivel e o tamanho dos danos variaram com os cultivares, com a firmeza do fruto no local do impacto e com a força do impacto. A cor do dano foi comparada às cores do índice de dano CDFA (índice de dano à fruta da Califórnia): $L=59,4, C=39,5$ e $H=70,3$. Danos mais escuros que $o$ índice do CDFA foram usados para calcular a porcentagem de descarte. Os estudos realizados durante duas safras mostraram que: a posição mais macia dos 5 cultivares foi o ombro. A firmeza média variou de 3 a 4 libras entre a posição mais macia e a mais firme no mesmo fruto, dependendo do cultivar. Os limites críticos de dano, nos impactos de 240, 320 e 360 G, dependeram do cultivar. A porcentagem de incidência de dano e o tamanho dos danos variaram com o cultivar, a posição do fruto na planta, a posição da fruta sob impacto, a firmeza 
da polpa na posição do impacto e a força do impacto. A firmeza limite para a ocorrência de dano visível num impacto de $240 \mathrm{G}(10 \mathrm{~cm}$ de altura) variou de 3,0 libras até 6,0 libras do cultivar "Stanislaus" para o cultivar "Starn". A diminuição da temperatura para 0 a $10^{\circ} \mathrm{C}$, logo após a colheita, diminuiu o aparecimento do dano. A firmeza limite, nos cinco cultivares, para cada altura de impacto variou de 3,0 a 6,0 libras para o impacto de $240 \mathrm{G}$ (100 mm de altura), de 5,0 a 6,5 libras para $320 \mathrm{G}$ (200 mm de altura) e de 6,0 a 9,0 libras para $360 \mathrm{G}$ (300 mm de altura). A medida foi feita com uma esfera instrumentada de 134 gramas e diâmetro de 60 milímetros, numa superfície de impacto emborrachada de 50 milímetros de espessura (Crisosto et al., 2.000).

A recomendação de Crisosto \& Kader (2000) para o manuseio do pêssego no varejo, para frutos com firmeza do fruto abaixo de 27 N, é a sua exposição em gôndolas refrigeradas, já para frutos com firmeza de polpa superior a 27 N, gôndolas à temperatura ambiente.

Berardinelli et al. (2001) simularam, em laboratório, os impactos medidos pela esfera instrumentada $(89 \mathrm{~mm}$ de diâmetro e 286 gramas) numa máquina de classificação de pêssego. Foram utilizadas 3 alturas de queda: 17, 30 e $85 \mathrm{~mm}$ em amostras de 30 frutos de três cultivares diferentes: 'Big Top', 'Caldesi 2000', 'Centry' e 'Rich Lady', em dois pontos da superfície do fruto: próximo ao pedúnculo e na zona equatorial. Foi considerado dano quando o tecido da polpa se apresentava mais translúcido que o tecido vizinho sem impacto. Para todos os cultivares, os níveis mais baixos de impacto não causaram nenhum dano visível. No nível mais alto de impacto foram observadas as alterações em 7 a $18 \%$ dos frutos. As dimensões 
das alterações não ultrapassaram $10 \mathrm{~mm}$ de diâmetro e $6 \mathrm{~mm}$ de profundidade. $\mathrm{O}$ dano, na maior parte das vezes, consistiu somente de uma pequena porção de polpa translúcida próxima à superfície, removido pelo descascamento do fruto. Os frutos do cultivar 'Big Top', mostraram algumas fraturas na polpa e a formação de pequenas cavidades. Em outro teste o fruto foi submetido ao impacto repetido, no mesmo ponto da sua superfície, em superfície de aço. No maior impacto a porcentagem de frutos danificados chegou a $18 \%$ e a dimensão média dos danos na polpa não foi superior a $10 \mathrm{~mm}$ de diâmetro no 'Big Top' e $6 \mathrm{~mm}$ de profundidade no 'Centry'. De uma maneira geral a repetição dos impactos no mesmo ponto não causou um aumento substancial de dano, exceto para o aumento da porcentagem de frutos danificados no cultivar 'Centry' e das dimensões do dano no cultivar 'Rich Lady'.

O desenvolvimento de cultivares de pêssego mais coloridos, trouxe maior dificuldade à visualização da cor do fundo e à determinação do ponto de colheita. Esse fato, aliado à insatisfação dos consumidores americanos com o sabor e à aspereza dos processos de colheita e a pós-colheita, fez com que Crisosto et al. (2001) desenvolvessem um método de determinação do indicador de maturação máxima para diferentes cultivares de frutas de caroço. 0 método estabelece o limite crítico de dano por impacto, tendo como base a medida da firmeza do fruto no seu ponto mais sensivel ao impacto. Foram estudados pêssegos de polpa amarela com diferentes firmezas em três niveis de impacto. Os frutos foram submetidos à queda em três alturas, sobre uma superfície de características conhecidas. O ponto mais sensível ao impacto no fruto variou com o cultivar: bico ou ombro. Somente áreas danificadas visíveis com 
diâmetro maior que $2,5 \mathrm{~mm}$ foram consideradas na contagem. As alturas de queda utilizadas foram: 10,50 e $100 \mathrm{~mm}$. Todos cultivares testados foram danificados com $100 \mathrm{~mm}$ de queda, com o índice de firmeza 9.

O estudo de Mattiuz (2002) avaliou o efeito de danos mecânicos por impacto, compressão e corte na fisiologia das goiabas 'Paluma' e 'Pedro Sato'. Os frutos, em queda livre, de uma altura de 1,20 m, sofreram impactos, em lados opostos da sua porção equatorial, na avaliação de dano por impacto. Os frutos foram submetidos a um peso de $29,4 \mathrm{~N}$ por 15 minutos, na avaliação de dano por compressão. Dois cortes foram efetuados longitudinalmente de $30 \mathrm{~mm}$ de comprimento por $2 \mathrm{~mm}$ de profundidade, na avaliação de dano por corte. Os efeitos dos danos mecânicos nos processos respiratórios, nas variáveis químicas e na firmeza e coloração dos frutos, foram medidos. A área danificada do fruto ficou mais escura, com o valor de $L^{*}$ maior. Os frutos danificados apresentaram irregularidade de amadurecimento, com o amarelecimento do fruto mais rápido na área danificada, exceção feita ao dano por compressão, quando o amarelecimento foi retardado. Os frutos, submetidos a danos mecânicos - corte, compressão e impacto -, produziram maior quantidade de $\mathrm{CO}_{2}$ que os frutos do controle. Os incrementos de produção de $\mathrm{CO}_{2}$ foram maiores no dano por impacto. O conteúdo de sólidos solúveis totais manteve-se estável durante o período de armazenamento. Houve uma tendência de valores menores de teor de sólidos solúveis nos frutos injuriados, principalmente no dano por impacto. Observou-se nos frutos danificados, menores teores de acidez que no controle, ao longo do período de avaliação. 
O estudo de Kasat (2004) avaliou o efeito na qualidade pós-colheita de pêssegos 'Aurora' - 1 ', de danos por impacto, compressão e corte. Para estudar o dano por impacto, os frutos sofreram queda livre sobre superfície maciça, plana e rígida, de uma altura de $1200 \mathrm{~mm}$. Para estudar o dano por compressão, os frutos foram colocados sobre uma superfície plana e um bloco, exercendo um peso de $3 \mathrm{~kg}$ por 10 minutos, foi colocado sobre eles, provocando duas lesões em lados opostos e no sentido longitudinal dos frutos. Para estudar o dano por corte, foi utilizada uma lâmina de $1,1 \mathrm{~mm}$ de espessura, $2 \mathrm{~cm}$ de comprimento por $2 \mathrm{~mm}$ de profundidade, fixada em uma superfície, e realizados dois ferimentos em uma das faces do fruto, em sentido longitudinal. $O$ fruto submetido ao impacto apresentou perda de massa fresca, perda de firmeza e diminuição da acidez titulável, superiores aos outros tratamentos: testemunha, compressão e corte.

A cor de fundo é o melhor indicador de maturação para o ponto de colheita (Delwiche \& Baumgardner, 1985). Diferenças de maturação são visíveis especialmente na medida a* das coordenadas de cor de Hunter, que aumenta com o avanço da maturação. Cada grupo de cor de fundo corresponde a uma amplitude de variação do a*: menor ou igual a -9 , entre -9 e -7 , entre -7 e -5 , entre -5 e 4 e maior ou igual $a-3$. Os valores $L^{*} e b^{*}$ crescem muito durante 0 desenvolvimento do fruto, principalmente no último mês antes da colheita, e não crescem mais depois da colheita. Os grupos de cor de fundo com a* variando de -9 a -5 , são melhores pontos de maturação para colheita, que os grupos de cor de fundo com a* entre -5 a menor que -3. A revisão dos estudos sobre a maturação de nectarina, ameixa e pêssego, publicados entre 1980 e 1992, feito por 
Crisosto (1994), debateu as vantagens e desvantagens dos diferentes indicadores de maturação. A cor de fundo, considerada um indicador impreciso, foi mesmo assim escolhida como o método mais prático e confiável para determinar a maturidade mínima para o ponto de colheita, e a firmeza da fruta, o melhor indicador da maturidade máxima. A variação dos sólidos solúveis é muito grande: entre pomares, na mesma árvore e o teor de sólidos solúveis não pode ser utilizado como um indicador do estádio de maturação da fruta.

Em pós-colheita considera-se, como maturo, o estádio em que o produto, depois de passar pela colheita e pós-colheita, consegue satisfazer o consumidor (Reid, 1992). A maturação acontece entre 0 crescimento final do fruto e 0 início do amadurecimento e senescência. Maturidade é o ponto final da maturação. Fruto imaturo pode amadurecer fora da árvore mas será de baixa qualidade. Fruto maturo atinge boa qualidade, amadurecido fora da árvore. Mudança da cor da casca e da polpa, amolecimento da polpa e desenvolvimento do aroma são características do amadurecimento, que promove a diminuição da frutose e da glicose e o aumento da sucrose. Há um declínio dos ácidos totais, resultante da perda do ácido málico, o aumento da taxa de respiração e da produção de etileno. O impacto pode acelerar as mudanças características do amadurecimento.

Levantamentos preliminares realizados no Entreposto Terminal de São Paulo, mostraram a grande incidência de danos póscolheita no pêssego. Os levantamentos foram feitos com o pêssego da Cooperativa Holambra II, da safra de 1998 à safra de 2001, e fazem parte do serviço de rotina de apoio ao produtor do Centro de Qualidade em Horticultura da CEAGESP, na adoção das normas de 
classificação do Programa Brasileiro para a Modernização da Horticultura. O serviço, de rotina diária, durante a safra de pêssego, começa pelo recebimento da informação enviada pela Cooperativa Holambra II do destino do seu pêssego, dentro do Entreposto Terminal de São Paulo. De posse dessa informação, enviada logo após o leilão, na noite anterior à chegada do produto no ETSP - Entreposto Terminal de São Paulo, os técnicos do Centro de Qualidade em Horticultura vistoriam diariamente os frutos enviados, registram os seus principais problemas e os comunicam imediatamente à Cooperativa. Na ocorrência de anomalias que determinem a renegociação do preço, a Cooperativa Holambra II só aceita a renegociação após um laudo de um dos técnicos do Centro de Qualidade em Horticultura. Durante a vistoria algumas informações são anotadas para cada lote, em cada atacadista: identificação do produtor, data do embalamento, data do controle, atacadista que recebeu o produto, cultivar do pêssego, classificação declarada no rótulo: categoria e calibre e principais anomalias (causas de desvalorização ou rejeição do produto). Foram realizadas vistorias, de 1998 a 2001, em 5506 lotes de pêssego. Entre as anomalias mais relatadas, referentes à qualidade do pêssego, estão o fruto amassado $(48,5 \%)$, o fruto com podridão $(31,57 \%)$, o fruto manchado $(7,64 \%)$. O dano no bico foi também registrado como fruto amassado. A participação do pêssego 'Aurora', cresceu de 1998 até 2001, de 25\% para $31 \%$ do total dos lotes vistoriados. Fruto amassado e com podridão foram as anomalias responsáveis pela maioria das ocorrências levantadas no pêssego 'Aurora'. A distribuição de anomalias para o pêssego 'Aurora' foi semelhante à composição do total das anomalias. Os resultados dos levantamentos, aqui descritos, 
não permitem quantificar a magnitude das anomalias na população total dos frutos vistoriados. 


\section{O PÊSSEgo NO ENTREPOSTO TERMINAL DE SÃo PAULO dA CEAGESP}

\section{Resumo}

O SIM - Sistema de Informação de Mercado - do Entreposto Terminal de São Paulo da CEAGESP - Companhia de Armazéns e Entrepostos Terminais de São Paulo - registra diariamente, através do recolhimento de uma via da nota fiscal na entrada do produto: a data de entrada, o produto e a sua variedade, o município de origem, a classificação, o tipo de embalagem e o atacadista de destino do produto. Todas essas informações de entrada e de destino de pêssego, de agosto de 2003 a janeiro de 2004, foram tabuladas e organizadas. Foram entrevistados: 40 compradores e 30 atacadistas, que compram e comercializam no Entreposto Terminal de São Paulo, na safra 2003-2004, para completar o retrato da comercialização do pêssego. O Entreposto Terminal de São Paulo da CEAGESP - Companhia de Entrepostos e Armazéns Gerais de São Paulo - é o responsável pelo escoamento de um volume equivalente a $44 \%$ da produção do Estado de São Paulo de 32 mil toneladas (IEA, 2004). Há uma grande diversidade de variedades e de origens. Na safra 2003-2004 foram registradas pelo SIM - Sistema de Informação de Mercado da CEAGESP, 17 variedades de pêssego, originárias de 
130 municípios e 9 estados do Brasil. A pulverização do destino no mercado atacadista é grande: 183 atacadistas, sendo que o maior atacadista responde por apenas $8,57 \%$ do volume e $010^{\circ}$ colocado por $2,84 \%$. A pulverização na produção é grande e pode ser aferida pelo volume médio da entrada diária por atacadista (1716 quilos por origem por atacadista) e pelo número de entradas por mês (2000 entradas por mês nos meses de maior movimento). O pêssego é um fruto de alta sazonalidade: $78,73 \%$ é comercializado nos meses de outubro, novembro e dezembro e é um dos dois produtos mais importantes para $50 \%$ dos atacadistas na época da safra. Frutos com podridão, com batidas e manchados foram as características de rejeição mais citadas $(51,5 \%)$ pelos compradores. Para os atacadistas, as maiores causas de desvalorização são a baixa qualidade dos frutos $(40 \%)$ e a ocorrência de frutos podres (17\%). 0 município de Paranapanema - SP, onde está localizada a Cooperativa Holambra II, foi o segundo maior fornecedor de pêssego (12,34\%), depois de Atibaia (18,44\%). A variedade 'Aurora', respondeu por $40,80 \%$ do volume total de comercialização de pêssego no Entreposto Terminal de São Paulo. O Entreposto Terminal de São Paulo da CEAGESP é um local adequado para o monitoramento da comercialização e dos problemas pós-colheita do pêssego fresco no mercado atacadista. O município de Paranapanema e a variedade 'Aurora' são representativos da produção de pêssego.

PALAVRAS-CHAVE: Prunus persica L., comercialização, atacado.

\section{THE PEACH AT SÃO PAULO TERMINAL MARKET}

\section{Summary}


The SIM - Market Information System of CEAGESP's São Paulo Terminal Market - has registered daily informations from the products invoice that are sent to the terminal market: entrance date, product, variety, municipality of origin, quality grade, volume, package, and the product destiny inside the terminal market. The SIM informations for peach, from August - 2003 to January - 2004 have been worked. Forty outside buyers and thirty wholesalers that buy and sell, respectively, at the ETSP - Sao Paulo Terminal Market, were interviewed, to a better understanding of the fresh peach marketing. The fresh peach volume marketed at the Sao Paulo Terminal Market is equivalent to $44 \%$ of Sao Paulo state production - 32 thousand tons. It was registered in this period - 17 peach varieties, 130 municipalities of origin of 9 brasilian states and 183 wholesalers. There is pulverization of destiny and origin. The major wholesaler receives $8,57 \%$ of the total peach volume and the tenth $2,84 \%$. The origin (production) pulverization can be measured by the daily medium volume sent by each grower to each wholesaler - 1716 kilos e by the number of entrances per month (2000 - October, November and December). The peach is a fruit of high seasonality, $78,73 \%$ of the total volume is marketed from October to December. The wholesaler interviewing has shown that peach is the first or second product more important in the season for $50 \%$ of the peach wholesalers. The major reasons for buyer rejection $(51,5 \%)$ are: fruits injured by bruise, skin defect and rotted; for fruit devaluation are: poor fruit quality (40\%) e the occurrence of rotted fruits $(17 \%)$. The municipality of Paranapanema, Sao Paulo state, where the Cooperativa Holambra II is located, is the second biggest peach state producer $(12,34 \%)$, only after Atibaia $(18,445)$, also in the state of Sao Paulo. The peach 
'Aurora" is responsible for $40,80 \%$ of the total peach volume marketed at Sao Paulo Terminal Market during the period studied. Sao Paulo's Terminal Market, by its volume and diversity, is a good place for monitoring fresh peach marketing and its post harvest disorders. The municipality Paranapanema and the peach 'Aurora' are representatives of the brasilian fresh peach.

KEY WORDS: Prunus persica L., whosale, marketing.

\subsection{Introdução}

A produção brasileira de pêssego não é suficiente para o seu consumo interno (Sato, 2001). O plantio de variedades mais adequadas ao clima quente em São Paulo e Paraná, a partir dos anos 70, alongou o período de oferta do pêssego fresco. Outra mudança importante foi a entrada de produtores maiores e mais tecnificados alterando o sistema de produção de pêssego fresco, até então, predominantemente artesanal.

O Entreposto Terminal de São Paulo da CEAGESP Companhia de Entrepostos e Armazéns Gerais de São Paulo - é o responsável pelo escoamento de um volume equivalente a $44 \%$ da produção do Estado de São Paulo de 32 mil toneladas (IEA, 2004).

O estudo de quantificação e a caracterização de danos mecânicos pós-colheita em pêssego exigem boa compreensão do processo de comercialização, visando o estabelecimento do adequado foco e da adequada estratégia de ação para a melhoria do processo de pós-colheita. O objetivo do presente trabalho é caracterizar a comercialização de pêssego fresco no Entreposto Terminal de São Paulo. 


\subsection{Material e Métodos}

No Entreposto Terminal de São Paulo da CEAGESP, é recolhida de cada veículo que entra trazendo mercadoria, uma via da nota fiscal. Essa via vai para o sistema de informação, onde se registra: a data de entrada, o produto e a sua variedade, o município de origem, a classificação, o tipo de embalaǵem e o atacadista de destino do produto. Esses dados compõem o SIM - Sistema de Informação de Mercado da CEAGESP, atualizado todos os dias, para a cadeia de produção de frutas, hortaliças, flores, plantas ornamentais e peixes. Todas as informações de entrada e de destino de pêssego, referentes ao período de agosto de 2003 a janeiro de 2004, disponíveis em forma bruta no SIM, foram tabuladas e organizadas volume mensal de entrada por origem, por variedade e por atacadista de destino, número de entradas por origem, por variedade e por atacadista de destino. As mesmas informações foram detalhadas para o pêssego originário do município de Paranapanema e para o pêssego 'Aurora'.

Visando obter-se uma boa compreensão do processo de comercialização do pêssego, foram entrevistados, através de questionários individualmente aplicados, 40 compradores, escolhidos ao acaso, e os 30 maiores atacadistas. Os compradores foram entrevistados no período da safra, de novembro a dezembro de 2.003 e os atacadistas, no início da safra, em agosto de 2003. Os questionários aplicados encontram-se nos Anexos A e B. Só uma parte das respostas será utilizada neste trabalho. O entrevistado não teve acesso ao questionário e o entrevistador não sugeriu opções de resposta ao entrevistado. 


\subsection{Resultados e Discussão}

A tabulação dos dados de entrada e destino do pêssego no Entreposto Terminal de São Paulo - ETSP mostrou que no período de agosto de 2.003 a janeiro de 2.004 foram comercializados 13.698.161 quilos de pêssego. O pêssego é uma fruta de alta sazonalidade - os meses de outubro a dezembro concentraram $78,73 \%$ da oferta (Tabela 1), originária de 130 municípios e de 9 estados brasileiros.

O Estado de São Paulo foi o responsável por $73 \%$ da produção do pêssego comercializado no ETSP, originário de 48 municípios, sendo que dez municípios paulistas dominaram o fornecimento de pêssego com $59 \%$ de todo o volume comercializado e $80 \%$ do volume do pêssego paulista. O município de Paranapanema, onde está localizada a Cooperativa Holambra II, que comercializa o pêssego produzido por seus cooperados pelo sistema de leilão reverso, é responsável por $9 \%$ de todo o pêssego nacional comercializado no Entreposto Terminal de São Paulo e 12,34\% do pêssego paulista (Tabela 2).

Tabela 1. Sazonalidade do pêssego na safra 2003-2004 no Entreposto Terminal de São Paulo

\begin{tabular}{lcc}
\hline \multicolumn{1}{c}{ Mês } & $\mathrm{Kg}$ & $\%$ \\
\hline Agosto & 153.974 & 1,12 \\
Setembro & 827.812 & 6,04 \\
Outubro & 3.327 .895 & 24,29 \\
Novembro & 3.235 .640 & 23,62 \\
Dezembro & 4.220 .763 & 30,81 \\
Janeiro & 1.932 .077 & 14,1 \\
\hline
\end{tabular}


Tabela 2. Participação dos principais municípios de São Paulo, fornecedores de pêssego no ETSP, na safra 2003- 2004, no total fornecido pelo Brasil e pelo Estado de São Paulo

\begin{tabular}{lcc}
\hline \multicolumn{1}{c}{ Município } & $\%$ Brasil & São Paulo \\
\hline Atibaia & 13,51 & 18,44 \\
Paranapanema & 9,04 & 12,34 \\
Guapiara & 6,23 & 8,5 \\
Valinhos & 5,42 & 7,39 \\
Transferência & 5,06 & 6,91 \\
Campinas & 4,96 & 6,77 \\
Jarinú & 4,91 & 6,71 \\
Ribeirão Branco & 3,84 & 5,24 \\
São Miguel Arcanjo & 3,2 & 4,37 \\
Pilar do Sul & 2,86 & 3,91 \\
Total & 59,04 & 80,58 \\
\hline
\end{tabular}

Foi registrada a entrada de 17 variedades de pêssego, sendo 4 variedades responsáveis por $90,49 \%$ do volume. O pêssego 'Aurora' foi o mais comercializado, com $40,80 \%$ do volume total de comercialização (Tabela 3). As variedades apresentaram diferentes distribuições ao longo da safra. Algumas variedades como 'Biuti', 'Branco Duro', 'Coral' e 'Natal' tiveram sua entrada registrada em 1 só mês. Outras, como 'Aurora', 'Dourado', 'Flor da Prince', 'Ouro Mel' foram registradas em todos os 6 meses (Tabela 4). O volume de entrada do pêssego 'Aurora' manteve uma proporção acima de 0,40 em relação ao volume total de entrada de agosto a dezembro, caindo para 0,21 em janeiro. 
Tabela 3. Volume das principais variedades de pêssego comercializadas no Entreposto Terminal de São Paulo na safra 2003-2004

\begin{tabular}{lcc}
\hline \multicolumn{1}{c}{ Variedade } & $\mathrm{Kg}$ & $\%$ \\
\hline Aurora & 5.588 .974 & 40,80 \\
Dourado & 3.536 .533 & 25,82 \\
Chimarrita & 2.653 .378 & 19,37 \\
Flor da Prince & 616.663 & 4,50 \\
Total & 12.395 .548 & 90,49 \\
\hline
\end{tabular}

Tabela 4. Número de meses de oferta por variedade de pêssego na safra 2003-2004, no Entreposto Terminal de São Paulo

Variedades

Número de meses

\begin{tabular}{ll}
\hline Aurora & 6 \\
Dourado & 6 \\
Flor da Prince & 6 \\
Ouro Mel & 6 \\
Chimarrita & 5 \\
Diamante & 5 \\
Alo Doçura & 4 \\
Jóia & 4 \\
Premier & 4 \\
Marli & 3 \\
Regis & 3 \\
Conserva & 2 \\
Chiripá & 2 \\
Beauty & 1 \\
Branco Duro & 1 \\
Coral & 1 \\
Natal & 1 \\
\hline
\end{tabular}

O pêssego foi comercializado por 183 atacadistas do ETSP neste período - sendo 12 atacadistas responsáveis por $50 \%$ do volume, 22 por $70 \%$ e 31 por $81 \%$. A concentração de vendas por 
atacadista é pequena. O primeiro colocado comercializa $8,57 \%$ do volume e o décimo 2,84\%. Entre os atacadistas, $8,06 \%$ comercializaram pêssego durante todo o período do levantamento de agosto a janeiro e acima de $12 \%$ dos atacadistas mantiveram a oferta do pêssego entre 5 a 2 meses. A maioria $(39,78 \%)$ se restringiu a 1 mês de oferta (Tabela 5).

Tabela 5. Número de meses de permanência dos atacadistas na comercialização de pêssego na safra 20032004, no Entreposto Terminal de São Paulo

\begin{tabular}{cc}
\hline$\%$ de atacadistas & $N .{ }^{\circ}$ de meses de oferta \\
\hline 8,06 & 6 \\
12,90 & 5 \\
13,44 & 4 \\
12,90 & 3 \\
12,90 & 2 \\
39,78 & 1 \\
\hline
\end{tabular}

A entrada do pêssego por origem por atacadista é muito pulverizada, quando consideramos a capacidade de um caminhão: 1716 quilos por origem por atacadista. O número e o volume de entradas do pêssego no ETSP mostra bem a pulverização da produção. As entradas, nos meses de outubro, novembro e dezembro, foram 2252, 2159 e 1749 respectivamente.

Com os dados do Sistema de Informação da CEAGESP, foi possivel traçar o perfil de produção do município de Paranapanema, onde está a sede da Cooperativa Holambra II. As variedades 'Aurora', 'Flor da Prince' e 'Dourado' são responsáveis por $96 \%$ do volume de pêssego originário do município de Paranapanema na safra 2003-2004. O pêssego 'Aurora' representou 29\% do volume 
total. A safra de pêssego do município de Paranapanema se estendeu de agosto a dezembro, com a maior oferta em outubro e novembro, meses que concentraram $73,3 \%$ do volume comercializado. A porcentagem de atacadistas do ETSP que comercializaram pêssego do município de Paranapanema, foi maior em agosto, com $40 \%$ dos atacadistas de pêssego, e se estabilizou em $30 \%$ em setembro e novembro, caindo para $20 \%$ em novembro e dezembro. Agosto é mês de início de safra e o município de Paranapanema domina a oferta de pêssego no ETSP.

A entrevista dos agentes de venda do pêssego, visando um melhor entendimento da sua comercialização, feita através da aplicação pessoal de um questionário, começou pelos atacadistas, no início da safra de pêssego, no final de agosto de 2003. Os quarenta compradores foram entrevistados no período forte da safra, de novembro a dezembro de 2.003.

A entrevista dos compradores trouxe alguns resultados interessantes: as feiras, os sacolões e os supermercados, cada um com cerca de $30 \%$ das respostas, dominaram o destino do pêssego nos equipamentos de varejo. Em seguida ficaram outros destinos, como outras ceasas, quitandas e varejão. A grande maioria dos compradores entrevistados (95\%) só compra pêssego no Entreposto Terminal de São Paulo. Metade dos compradores compra pêssegos de 1 a 3 atacadistas e metade compra ao acaso, de acordo com a melhor oferta. Doze atacadistas foram citados pelos compradores, como seus principais fornecedores: um deles foi citado por $50 \%$ dos compradores, três por 17\%. A maior parte dos compradores vem comprar pessoalmente no mercado $(72,5 \%)$, uma outra parte compra também por telefone $(22,5 \%)$. Uma parte muito pequena 
compra só por telefone ou fax, cerca de 2,5\%, cada um. O comprador prefere verificar pessoalmente o produto na hora da compra. É bom lembrar que o questionário foi aplicado aos compradores encontrados no Entreposto Terminal de São Paulo. A freqüência semanal de compra é alta. Quase metade dos entrevistados, compra três vezes por semana, seguida de cinco, quatro, seis e uma vez por semana, com 17,5\%, 12,5\%, 10,0\% e $5 \%$ respectivamente. A perecibilidade do pêssego exige compras freqüentes.

Entre as características citadas pelos compradores, como fatores de rejeição de compra do pêssego, estão a podridão $(21,4 \%)$, seguida por pêssego batido $(16,2 \%)$, manchado $(13,9 \%)$, muito maduro $(13,3 \%)$, tamanho pequeno $(11,0 \%)$, embalagem ruim $(8,7 \%)$, muito verde $(7,5 \%)$ e pouco colorido $(1,2 \%)$. Entre os cuidados que devem ser tomados para conservar a qualidade do pêssego, $50 \%$ do entrevistados citaram a refrigeração e o restante se dividiu entre melhoria no armazenamento, no transporte, na logística e no manuseio.

Entre as variedades citadas pelos compradores estão o pêssego 'Douradão' (15,5\%), o 'Aurora' e o 'Jóia', com 14,4\% cada um, o 'Dourado', o 'Chiripá', o 'Flor da Prince', de 10\% a 12\% cada um, o 'Ouro Mel' e o 'Chimarrita' com mais de $5 \%$ cada um e outros pouco citados. Apesar do grande número de variedades de pêssego, o comprador que vem ao mercado, consegue identificá-las. O 'Douradão' é um dos pêssegos mais valorizados e um dos mais lembrados.

Os 30 atacadistas entrevistados são responsáveis por $27,78 \%$ do volume de pêssego comercializado na safra 2003-2004, 
no ETSP. Para cerca de metade dos atacadistas entrevistados o pêssego ocupa o primeiro $(30,8 \%)$ e o segundo $(11,5 \%)$ lugar entre os produtos que comercializa, na época de safra. O estado de São Paulo é o principal fornecedor para 55,2\% dos entrevistados, seguido pelo Rio Grande do Sul (21\%) e em seguida por Minas Gerais, Paraná e Santa Catarina. O pêssego 'Douradão' é considerado a melhor variedade por $41,5 \%$ dos atacadistas, seguido pelo 'Chiripá' $(12,2 \%)$, 'Dourado' (9,8\%), 'Aurora', 'Chimarrita', 'Marli', 'Ouro Mel' com 7,3\% cada um, 'Coral' $(4,9 \%)$ e finalmente 'Flor da Prince' com 2,4\%. A escolha da melhor variedade pelo atacadista confirmou a preferência do comprador: 40\% consideraram como a melhor variedade o 'Douradão', seguido pelo 'Aurora' (15\%), o 'Chimarrita' e o 'Chiripá' com $10 \%$ cada um, o 'Ouro Mel' com $5 \%$ e outros.

Dos atacadistas entrevistados, 90\% manifestaram uma alta expectativa de manutenção e ou aumento da exigência de qualidade nos próximos anos. Entre as principais causas de desvalorização, citadas pelos atacadistas, estão a qualidade (40\%), seguida pela podridão (17\%) e pela classificação (13\%). A qualidade é considerada como o principal problema na comercialização do pêssego por $40 \%$ dos entrevistados, seguida pela classificação mal feita $(26 \%)$ e pela podridão (17\%). Entre as principais reclamações dos compradores para os atacadistas estão o sabor (29\%), seguido pelo calibre e pela má qualidade da embalagem com $25 \%$ cada um, pela perecibilidade do fruto (15\%) e pela lanosidade (dano por frio), com $3 \%$ das respostas.

As reclamações dos compradores registradas na entrevista não são as mesmas registradas nas entrevistas dos atacadistas, o que mostra uma falta de percepção do atacadista, dos 
problemas dos compradores. O fruto batido, citado pelos compradores como um dos principais problemas $(16,2 \%)$ do pêssego, não é citado pelo atacadista, que não deve sentir com tanta intensidade o problema e deve englobá-lo dentro das causas de desvalorização e dos principais problemas na comercialização como qualidade. O impacto da batida no fruto é mais visível com o tempo. O sistema de exposição a granel e a escolha da fruta pelo consumidor no varejo, que possibilita uma avaliação individual de cada fruto pelo consumidor, aumenta muito o manuseio do fruto, danificando-o e tornando mais evidente o dano por batida.

\subsection{Conclusões}

O Entreposto Terminal de São Paulo da CEAGESP, responsável pelo escoamento de $44 \%$ da produção paulista de pêssego, é um local adequado para o monitoramento da comercialização e dos problemas pós-colheita do pêssego fresco no mercado atacadista.

O município de Paranapanema, origem de $12,34 \%$ do pêssego paulista, e a variedade 'Aurora' $(40,8 \%$ do volume comercializado) são representativos da produção atual de pêssego e podem ser utilizados no estudo dos problemas pós-colheita do pêssego fresco.

Os meses de outubro a dezembro concentram $78,73 \%$ do volume comercializado e são a melhor época para o levantamento de problemas pós-colheita. Frutos com podridão, com batida e manchados são as principais causas de rejeição do pêssego $(51,5 \%)$ pelos compradores, no momento da compra no mercado atacadista. 


\section{DANOS MECÂNicos Pós-COlHeita de pÊssegos No MERCADO ATACADISTA}

\section{Resumo}

Os pêssegos são frutos delicados, bastante sensíveis a danos pós-colheita. A ocorrência de distúrbios pós-colheita em pêssegos frescos é uma importante causa de desvalorização ou rejeição do produto na comercialização. Este trabalho teve por objetivos quantificar e caracterizar os danos pós-colheita mecânicos em pêssegos no Entreposto Terminal de São Paulo da CEAGESP, o maior entreposto atacadista do estado de São Paulo e do Brasil. Foram realizados levantamentos de incidência de danos em $1 \%$ dos frutos comercializados no ETSP, em cada data de avaliação, no período de outubro de 2001 a janeiro de 2002 e de outubro de 2002 a janeiro de 2003. A amostragem foi estratificada por variedade de pêssego. Todos os frutos da amostra foram avaliados no próprio ETSP, onde foram quantificados os danos bióticos e abióticos, que compreendem os danos mecânicos. Foram amostrados em média 1835 frutos por avaliação. Os danos pós-colheita variaram de 5,5\% a 45,4\% dos frutos amostrados. Houve uma variação de $0,13 \%$ a $19,90 \%$ na ocorrência de frutos com danos mecânicos e de 4,3\% a 11,4\% de frutos com danos bióticos, sendo os danos mecânicos, em média, mais elevados que os danos bióticos. A proporção de ocorrência de 
anomalias no pêssego dessa safra foi muito alta, chegando a $100 \%$ das caixas amostradas. Foram contabilizados como dano mecânico: frutos batidos, prensados, raspados, cortados e danificados pela unha do colhedor. Existe correlação entre a freqüência de frutos com dano mecânico e a freqüência de frutos com danos bióticos. A ocorrência de anomalias foi menor no início da safra, quando o volume da colheita é menor e o fruto é colhido com maior firmeza de polpa. O sistema de produção e o manejo pós-colheita do pêssego, adotados pelo produtor, foram determinantes na severidade da incidência de danos mecânicos e bióticos. Para um melhor dimensionamento do problema e o desenvolvimento de uma estratégia de melhoria, é preciso quantificar o efeito dos danos pós-colheita na comercialização, seja na rejeição, seja na desvalorização do fruto pelos compradores e identificar o ponto da cadeia de produção onde ocorrem os danos.

PALAVRAS-CHAVE: Prunus persica L., anomalias, qualidade, batida.

\section{FRESH PEACHES POSTHARVEST MECHANICAL DISORDERS AT THE TERMINAL MARKET}

\section{Summary}

Peaches are fragile fruits, very suscetible to post harvest disorders. The post harvest disorders are an important reason for rejection and depreciation of fresh market peach. Fresh peach, 2002-2003 harvest, was inspected at São Paulo Fruit and Vegetable Terminal Market, ETSP/CEAGESP, to measure and describe the disorders, in special mechanical post harvest disorders. Incidence of damage was assessed in $1 \%$ of the marketed fruits in CEAGESP, in 
each date of evaluation during the periods from October 2002 to January 2003. The sampling was stratified on a peach variety basis. All fruits of the sample (one package) were evaluated in CEAGESP where biotic and abiotic damages were quantified. In average 1835 fruits were sampled in each evaluation. The incidence of mechanical post harvest disorders has ranged from $0,13 \%$ to $19,90 \%$ and of biotic disorders from $4,30 \%$ to $11,40 \%$. The mechanical damages were more frequent than the biotic damages. The incidence of mechanical disorders per sample was very high, $100 \%$ per sample for mechanical disorders. Fruits - bruised, damaged by compression, open damaged (pulp exposure), nail damaged - have been registered as mechanical damages. There was correlation between mechanical and biotic damages. The incidence of damages was smaller in the beginning of the peach season, when the production is smaller and the peach is harvested harder. There was a significant difference between different origins (growers), showing that the production and postharvest systems at production are the best quality determinators. The development of a prevention strategy for peach disorders needs the identification of where the disorders occur, from harvest to the consumer, and a better understanding of the effect of the disorders in the marketing value of fresh peaches.

KEY WORDS: Prunus persica L., bruising injury, quality.

\subsection{Introdução}

O mercado atacadista de frutas e hortaliças frescas concentra o produto e os seus problemas. O Entreposto Terminal de São Paulo concentra cerca de $18 \%$ da produção nacional de pêssego e 
$44 \%$ da produção paulista e é um bom local para o monitoramento dos problemas de pós-colheita do pêssego fresco brasileiro.

Levantamentos realizados no Entreposto Terminal de São Paulo, pelo $\mathrm{CQH}$ - Centro de Qualidade em Horticultura da CEAGESP, mostram a grande incidência de danos pós-colheita no pêssego. Os levantamentos foram feitos com o pêssego da Cooperativa Holambra II, de 1998 a 2001 (nos meses de agosto a dezembro), e fazem parte do serviço de rotina de apoio ao produtor do $\mathrm{CQH}$, na adoção das normas de classificação do Programa Brasileiro para a Modernização da Horticultura. O serviço, de rotina diária, durante a safra de pêssego, começa pelo recebimento da informação enviada pela Cooperativa do destino do seu pêssego, dentro do Entreposto Terminal de São Paulo. De posse desta informação, enviada logo após o leilão, na noite anterior à chegada do produto no ETSP - Entreposto Terminal de São Paulo, os técnicos do Centro de Qualidade em Horticultura vistoriam os frutos, registram os seus principais problemas e os comunicam imediatamente à Cooperativa. $\mathrm{Na}$ ocorrência de anomalias que determinem a renegociação do preço, a Cooperativa de Holambra só aceita a renegociação após um laudo técnico do Centro de Qualidade em Horticultura. Durante a vistoria algumas informações são anotadas para cada lote, em cada atacadista: identificação do produtor, data do embalamento, data do controle, atacadista que recebeu o produto, cultivar do pêssego, classificação declarada no rótulo (categoria e calibre) e principais anomalias (causas de desvalorização ou rejeição do produto). Foram realizadas vistorias, de 1998 a 2001, em 5506 lotes de pêssego de todas as variedades. Entre as anomalias mais relatadas, estão fruto amassado $(48,5 \%)$, fruto com podridão 
$(31,57 \%)$ e fruto manchado $(7,64 \%)$. A anomalia registrada como dano no bico foi também registrada como fruto amassado (Tabela 6). O pêssego 'Aurora', cresceu de 1998 até 2001, de $25 \%$ a $31 \%$ do número total dos lotes vistoriados, o que reflete o aumento da sua produção. Fruto amassado e com podridão foram os responsáveis pela maioria das ocorrências levantadas no pêssego 'Aurora' (Tabela 7). A distribuição de anomalias para o pêssego 'Aurora' foi semelhante à composição total das anomalias para todos os cultivares.

Tabela 6. Porcentagem de frutos amassados e com podridão em relação ao total de anomalias registradas de 1998 a 2001, em pêssegos avaliados no ETSP

\begin{tabular}{lccc}
\hline \multicolumn{1}{c}{ Ano } & Amassado & Podridão & Total \\
\hline 1998 & 58 & 26 & 84 \\
1999 & 82 & 6 & 88 \\
2000 & 43 & 40 & 83 \\
2001 & 50 & 40 & 90 \\
Média & 58 & 28 & 86 \\
\hline
\end{tabular}

Tabela 7. Porcentagem de frutos amassados e com podridão em relação ao total de anomalias registradas de 1998 a 2001, em pêssegos 'Aurora', avaliados no ETSP

\begin{tabular}{lccc}
\hline \multicolumn{1}{c}{ Ano } & Amassado & Podridão & Total \\
\hline 1998 & 60 & 29 & 89 \\
1999 & 90 & 0 & 90 \\
2000 & 56 & 39 & 95 \\
2001 & 33 & 67 & 100 \\
Média & 60 & 34 & 94 \\
\hline
\end{tabular}

Os resultados dos levantamentos, aqui descritos, não permitiram quantificar a magnitude das anomalias na população total 
dos frutos vistoriados, porque não foi registrado o número de caixas de cada lote, mas o número de lotes vistoriados.

Este trabalho tem por objetivos quantificar os danos mecânicos em pêssegos no Entreposto Terminal de São Paulo da CEAGESP, o maior entreposto atacadista do Estado de São Paulo.

\subsection{Material e Métodos}

Este trabalho é parte do estudo de "Quantificação de perdas de frutos em pós-colheita e difusão de tecnologia para identificação de suas causas e seu controle", em andamento desde 2001, financiado pelo Programa de Políticas Públicas da FAPESP (Martins et al., 2003).

Foram realizados levantamentos semanais na safra 2002-2003 (Tabela 8). Em cada levantamento foram vistoriados todos os pêssegos de $1 \%$ das caixas comercializadas pelos cinco maiores atacadistas de pêssego do Entreposto Terminal de São Paulo da CEAGESP, totalizando 25.975. A seleção das amostras foi feita por amostragem estratificada, utilizando como critério de estratificação o cultivar do pêssego (Tabela 9). Cada amostra correspondeu a uma caixa de pêssegos. Apenas as embalagens adequadamente etiquetadas foram vistoriadas. Todos os frutos de cada amostra foram inspecionados visualmente e cada anomalia foi descrita num formulário (Anexo $\mathrm{C}$ ) que continha as seguintes informações: número da amostra, data de colheita, procedência (produtor), cultivar, calibre, tipo de embalagem (caixas de madeira, de papelão ou de plástico), tipo de acondicionamento dos frutos na embalagem (granel ou em bandejas plásticas), número de frutos por embalagem, anomalias 
bióticas, anomalias fisiológicas e injúrias mecânicas. Frutos, com anomalias bióticas não identificadas, foram numerados e acondicionados em embalagens plásticas com células individuais e, em seguida, transportados aos laboratórios da ESALQ, onde foram incubados em câmaras úmidas por 24 horas. As anomalias de origem abiótica foram separadas em dano mecânico e anomalia fisiológica, em função da sintomatologia. Foram contabilizados como dano mecânico: frutos batidos, prensados, raspados, cortados e danificados pela unha do colhedor (Figuras 1 e 2).

Os dados foram submetidos à análise de correlação para relacionar danos mecânicos a danos bióticos e fisiológicos. Esses dados também foram analisados para identificar diferenças de incidência de danos entre os diferentes produtores e entre os cultivares comercializados em maior volume ('Aurora', 'Chiripá', 'Dourado', 'Douradão', 'IAC' e 'Ouromel'). As comparações da incidência de danos por produtor e da incidência de danos mecânicos por variedade foram feitas pelo teste $F$, considerando cada data de amostragem como uma repetição. 
Tabela 8. Datas de amostragem, número de caixas vistoriadas e número de pêssego examinados em cada avaliação na safra 2002-2003 no ETSP da CEAGESP

\begin{tabular}{lcc}
\hline Data de avaliação & Caixas $\left(n .^{\circ}\right)$ & Frutos $\left(n .^{\circ}\right)$ \\
\hline $09 / 10 / 2002$ & 20 & 2549 \\
$16 / 10 / 2002$ & 35 & 4008 \\
$22 / 10 / 2002$ & 23 & 2281 \\
$29 / 10 / 2002$ & 36 & 3453 \\
$05 / 11 / 2002$ & 18 & 2047 \\
$12 / 11 / 2002$ & 17 & 1724 \\
$20 / 11 / 2002$ & 26 & 2542 \\
$26 / 11 / 2002$ & 19 & 1687 \\
$02 / 12 / 2002$ & 11 & 861 \\
$16 / 12 / 2002$ & 16 & 866 \\
$07 / 01 / 2003$ & 13 & 934 \\
$14 / 01 / 2003$ & 14 & 1239 \\
$21 / 01 / 2003$ & 17 & 1225 \\
$28 / 01 / 2003$ & 6 & 559 \\
\hline
\end{tabular}


Tabela 9. Representatividade (porcentagem) de cada cultivar de pêssego no total de amostras analisadas na safra 20022003 no ETSP da CEAGESP

Cultivar

Safra $2002-2003$

\begin{tabular}{lc}
\hline Chiripá & 15,90 \\
'Aurora' & 25,70 \\
Dourado & 21,90 \\
Douradão & 7,30 \\
Coral & - \\
Premier & 1,10 \\
Chimarrita & 2,70 \\
Ouromel & 5,70 \\
Marli & 2,10 \\
Biuti & 2,70 \\
Natal & - \\
Tropical & - \\
Flor da Prince & 1,50 \\
Diamante & - \\
Eldorado & - \\
Regis & 1,10 \\
IAC & 7,90 \\
Flor 4/11/12 & 3,10 \\
Dourado 2/3 & 0,80 \\
Jóia 4 & 0,50 \\
\hline
\end{tabular}



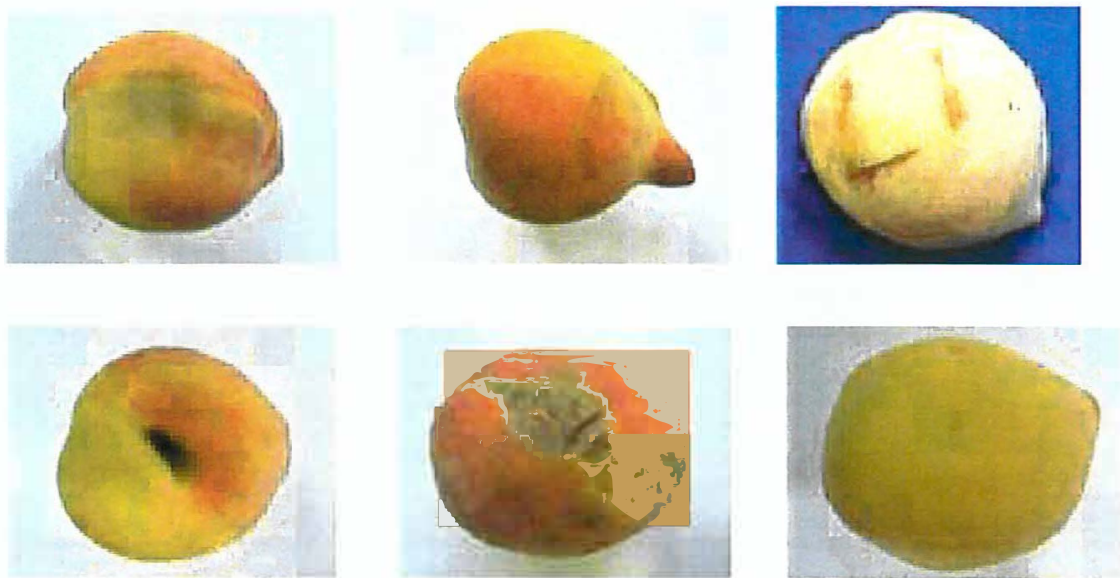

Danos mecânicos (abióticos)
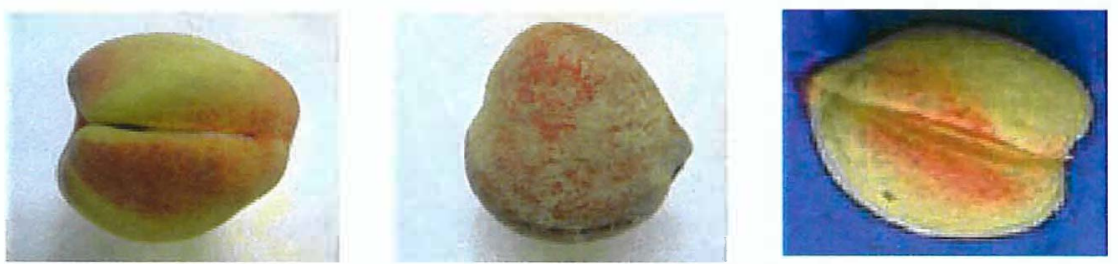

Danos fisiológicos (bióticos)
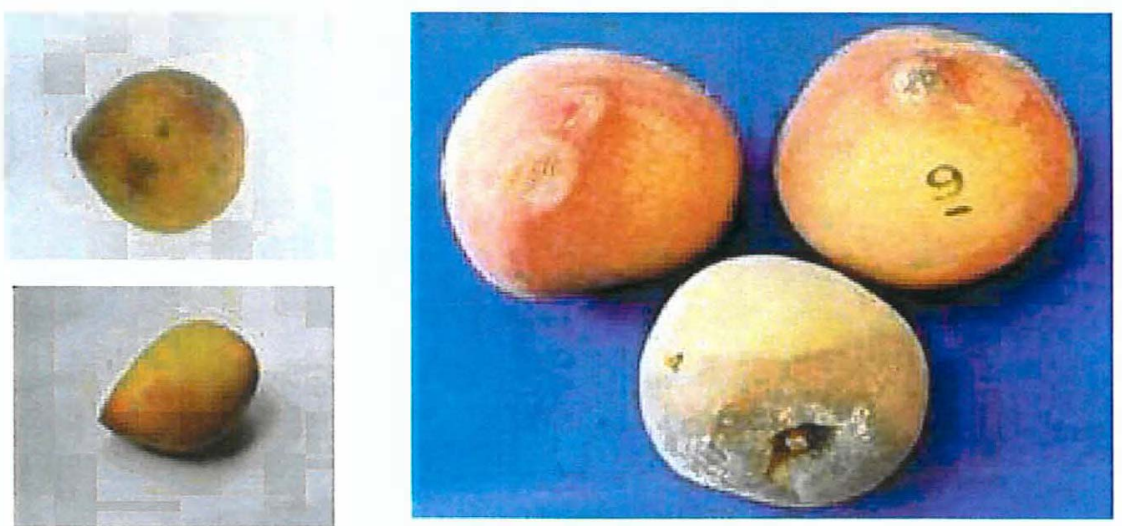

Anomalias bióticas

Figura 1 - Danos mecânicos, fisiológicos e de origem biótica na póscolheita de pêssego 


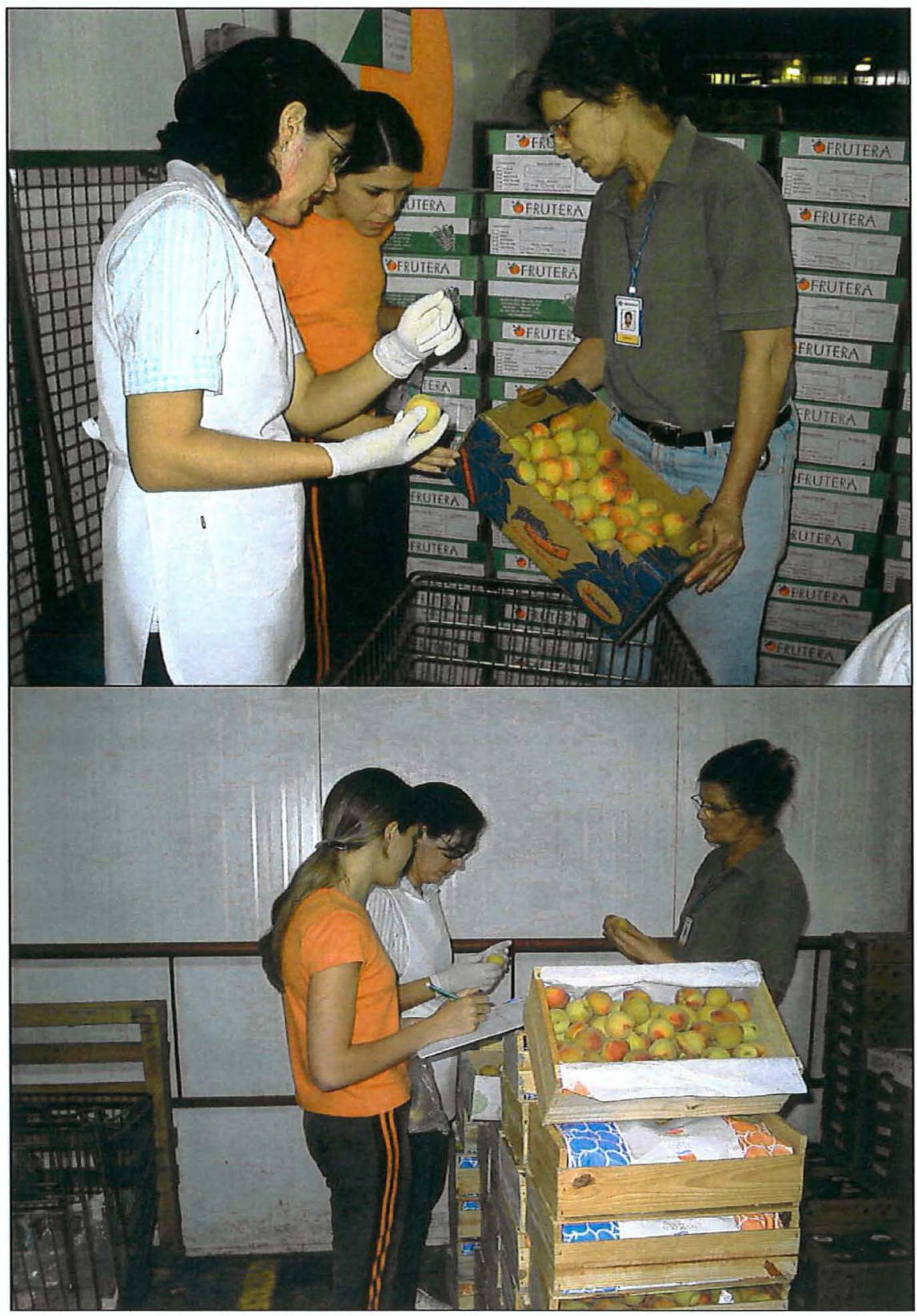

Vistoriando os pêssegos

Figura 2 - Levantamento dos danos pós-colheita de pêssego no mercado atacadista 


\subsection{Resultados e Discussão}

Os danos pós-colheita, expressos em porcentagem de frutos amostrados, variaram de 5,50 a 45,40 \%. Os danos mecânicos variaram de 0,13 a $19,90 \%$ e os danos bióticos de 4,30 a $11,40 \%$ dos frutos (Tabela 10 e figura 3). Os danos mecânicos foram, em média, mais elevados que os danos bióticos. A porcentagem de danos mecânicos foi pequena no início da safra, agosto e setembro e teve um pico na metade de dezembro. Dezembro é o mês de grande entrada de pêssego de cultivares de polpa branca e fundentes, menos resistentes ao manuseio. O início da safra é caracterizado por um pequeno volume de oferta e preços altos, o que leva o produtor a antecipar a colheita e a colher o pêssego um pouco mais duro. $O$ grande volume de colheita de pêssego, no pico da safra, dificulta o manuseio cuidadoso e faz com que o fruto seja colhido mais maduro, com firmeza de polpa menor, o que diminui a sua resistência a impactos. O trabalho de Schulte et al. (1994) mostra bem a diferença de resistência entre o fruto macio e o fruto firme - com uma queda de $100 \mathrm{~mm}$ de altura houve $100 \%$ de dano em fruto macio, mas foi necessária uma queda de $200 \mathrm{~mm}$ de altura para conseguir o mesmo efeito em fruto firme. 
Tabela 10. Porcentagem de pêssegos com danos mecânicos, bióticos e totais no ETSP

\begin{tabular}{lccc}
\hline $\begin{array}{l}\text { Data de } \\
\text { avaliação }\end{array}$ & $\begin{array}{c}\text { Danos } \\
\text { mecânicos \% }\end{array}$ & $\begin{array}{c}\text { Danos bióticos } \\
\%\end{array}$ & $\begin{array}{c}\text { Danos totais } \\
\%\end{array}$ \\
\hline $09 / 10 / 2002$ & 0,13 & 4,92 & 5,47 \\
$16 / 10 / 2002$ & 2,98 & 9,58 & 16,25 \\
$22 / 10 / 2002$ & 6,73 & 11,38 & 27,51 \\
$29 / 10 / 2002$ & 7,12 & 4,32 & 28,3 \\
$05 / 11 / 2002$ & 6,73 & 6,50 & 30,46 \\
$12 / 11 / 2002$ & 6,64 & 6,08 & 34,61 \\
$20 / 11 / 2002$ & 10,67 & 5,79 & 34,90 \\
$26 / 11 / 2002$ & 12,34 & 10,84 & 36,74 \\
$02 / 12 / 2002$ & 9,47 & 6,92 & 27,25 \\
$16 / 12 / 2002$ & 19,90 & 10,84 & 45,42 \\
$07 / 01 / 2003$ & 8,10 & 5,47 & 36,88 \\
$14 / 01 / 2003$ & 9,31 & 7,61 & 36,34 \\
$21 / 01 / 2003$ & 10,19 & 5,15 & 26,27 \\
$28 / 01 / 2003$ & 12,20 & 3,65 & 27,97 \\
\hline
\end{tabular}




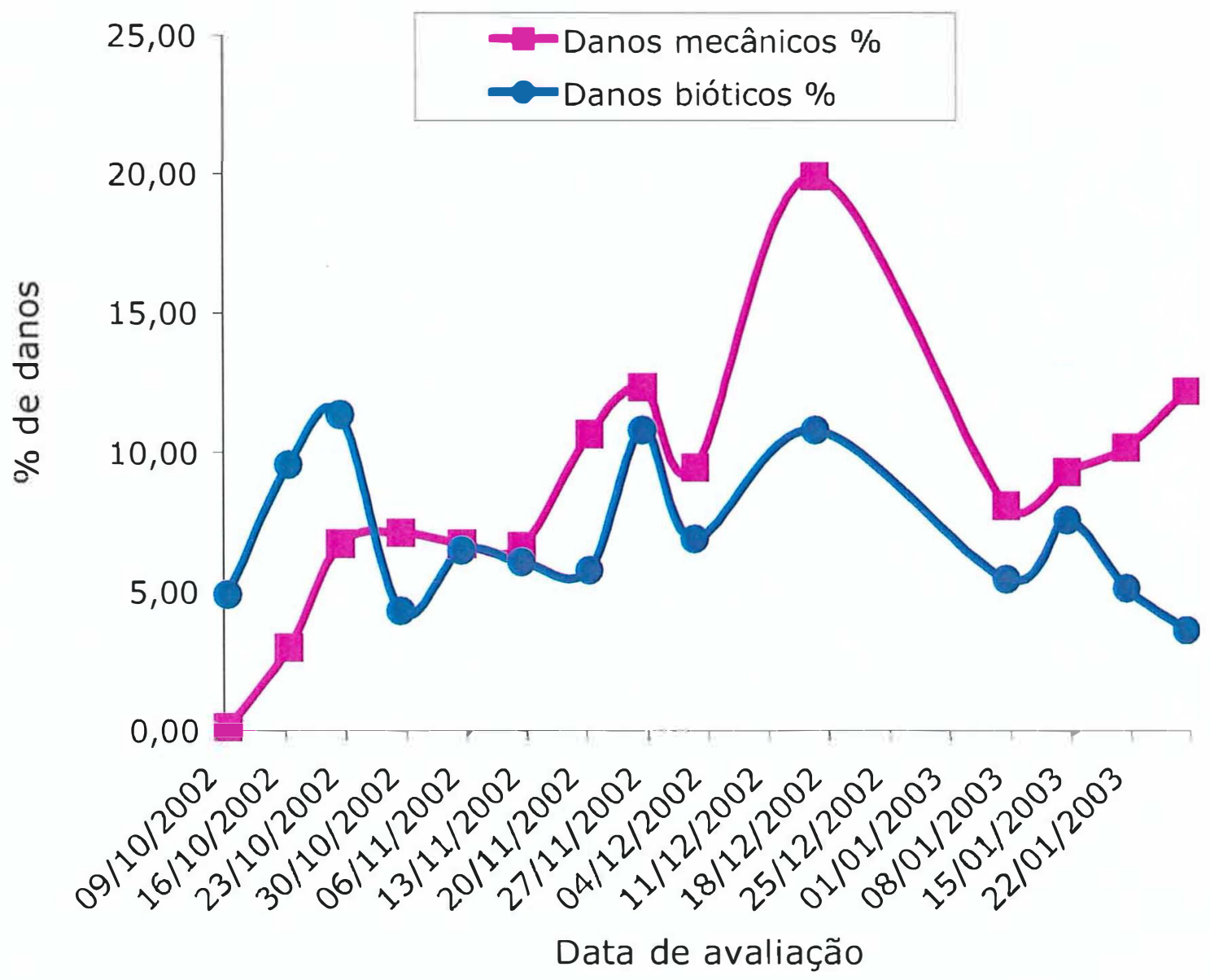

Figura 3 - Porcentagem de danos pós-colheita (bióticos e mecânicos) em pêssegos, na safra 2002-2003, avaliados no ETSP da CEAGESP 
Foi constatada correlação entre a freqüência de frutos com dano mecânico e a freqüência de frutos com podridões nas diferentes amostras $(r=0,52)$. Esta constatação reforça Bolin et al. (1997) que afirma que a redução de dano e a preservação da integridade fisiológica das frutas e hortaliças frescas garantem uma baixa população de microorganismos e a diminuição da integridade leva a uma alta população de microorganismos. Não houve correlação entre danos mecânicos e danos fisiológicos.

A partir da terceira data de avaliação, todas as caixas exibiram pelo menos um fruto com alguma anomalia. Foram realizados catorze levantamentos, ao longo de quatro meses: outubro, novembro, dezembro e janeiro, em pêssegos originários de 43 produtores. O fornecimento se concentrou em dois grandes produtores do município de Paranapanema, responsáveis por $26,90 \%$ das amostras do pêssego avaliado. A Cooperativa Holambra II, com 25 cooperados, foi responsável pelo fornecimento de $44,70 \%$ do total de amostras avaliadas. O município de Paranapanema foi a origem de $71,6 \%$ do pêssego avaliado. Não houve diferença significativa entre os diferentes tipos de embalagens, embalamento, calibre e cultivares. Houve diferença significativa na porcentagem de danos mecânicos por produtor pelo teste $F(a<0,05)$, mostrando que quem determina a qualidade do fruto é o produtor. Os cuidados do produtor são visíveis na diferença significativa de incidência de danos mecânicos entre os maiores produtores. Foi feita uma comparação entre os seis maiores produtores do município de Paranapanema, responsáveis pelo maior número de amostras avaliadas, sendo os três da Cooperativa, responsáveis pelo fornecimento de $42,40 \%$ das amostras avaliadas. A 
porcentagem de incidência de dano mecânico entre eles variou de $4,82 \%$ a $13,58 \%$ (Tabela 11 ).

Tabela 11. Porcentagem de danos mecânicos e número de amostras avaliadas por produtor entre os seis maiores produtores avaliados

\begin{tabular}{ccc}
\hline Produtor & \%danos mecânicos & \% total das amostras \\
\hline 1 & $13,58 \mathrm{a}$ & 4,55 \\
2 & $4,82 \mathrm{~d}$ & 4,55 \\
3 & $9,65 \mathrm{~b}$ & 4,55 \\
4 & $4,92 \mathrm{~d}$ & 16,20 \\
5 & $6,30 \mathrm{C}$ & 1,21 \\
6 & $6,44 \mathrm{C}$ & 10,21 \\
Total & 45,71 & 41,27 \\
\hline
\end{tabular}

No pêssego 'Aurora', que representou $25,70 \%$ das amostras avaliadas na safra de 2002-2003, a porcentagem de frutos danificados totais variou, nas 8 primeiras datas de avaliação (Tabela 13), de 4,97\% para 71,39\%. A porcentagem de danos mecânicos ficou entre 5,01 e 11,38\%, uma amplitude de variação muito menor que a dos danos bióticos que ficou entre 6,28\% e 42,29\%, eliminando-se a primeira avaliação (Tabela 14 e figura 6), mostrando uma maior uniformidade de ocorrência de danos mecânicos que os bióticos.

Os níveis de danos constatados na safra 2002-2003 no Entreposto Terminal de São Paulo da CEAGESP foram superiores aos relatados por Cappellini \& Ceponis (1984) nos Estados Unidos da América. Nos Estados Unidos, o pêssego fresco é comercializado sob refrigeração, o que atrasa o desenvolvimento dos microorganismos (Crisosto et al. 2001). No Brasil, o pêssego fresco é comercializado, 
em sua quase totalidade, sem refrigeração e quando refrigerado, sofre o efeito da quebra da cadeia do frio, com condensação de água sobre o fruto e aceleração da senescência.

A freqüência de caixas com pelo menos um fruto danificado foi muito elevada, com $100 \%$ das amostras contendo pelo menos um fruto danificado a partir da terceira avaliação e que reflete o aumento do volume colhido e da maturação mais avançada do fruto na colheita na ocorrência dos danos pós-colheita (Tabela 12).

Tabela 12. Proporção ${ }^{1}$ de amostras (caixas de pêssegos) com danos bióticos e mecânicos na safra 2002-2003

\begin{tabular}{lcc}
\hline Data de avaliação & $\begin{array}{c}\text { Danos bióticos } \\
\text { (proporção) }\end{array}$ & $\begin{array}{c}\text { Danos mecânicos } \\
\text { (proporção) }\end{array}$ \\
\hline $09 / 10 / 2002$ & 0,85 & 0,15 \\
$16 / 10 / 2002$ & 0,91 & 0,74 \\
$22 / 10 / 2002$ & 0,83 & 1,00 \\
$29 / 10 / 2002$ & 0,86 & 1,00 \\
$05 / 11 / 2002$ & 0,83 & 1,00 \\
$12 / 11 / 2002$ & 0,71 & 1,00 \\
$20 / 11 / 2002$ & 0,73 & 1,00 \\
$26 / 11 / 2002$ & 0,47 & 1,00 \\
$02 / 12 / 2002$ & 0,64 & 1,00 \\
$16 / 12 / 2002$ & 0,69 & 1,00 \\
$07 / 01 / 2003$ & 0,77 & 1,00 \\
$14 / 01 / 2003$ & 0,93 & 1,00 \\
$21 / 01 / 2003$ & 0,82 & 1,00 \\
$28 / 01 / 2003$ & 0,67 & 1,00 \\
\hline
\end{tabular}

${ }^{1}$ Proporção - relação entre o número de amostras com anomalia e o número total de amostras. 
Tabela 13. Datas de amostragem, número de caixas vistoriadas e número de pêssegos 'Aurora'1 examinados em cada avaliação na safra 2002-2003 no ETSP da CEAGESP

Data de avaliação

Caixas $\left(n .^{\circ}\right)$

Frutos $\left(n .^{\circ}\right)$

\begin{tabular}{lcc}
\hline $09 / 10 / 2002$ & 12 & 1645 \\
$16 / 10 / 2002$ & 20 & 1460 \\
$22 / 10 / 2002$ & 5 & 558 \\
$29 / 10 / 2002$ & 16 & 1069 \\
$05 / 11 / 2002$ & 11 & 784 \\
$12 / 11 / 2002$ & 5 & 561 \\
$20 / 11 / 2002$ & 4 & 298 \\
$26 / 11 / 2002$ & 1 & 139 \\
\hline
\end{tabular}

1 As amostras do pêssego 'Aurora' representaram 25,70\% do total das amostras avaliadas

Tabela 14. Porcentagem de frutos do pêssego 'Aurora' com danos totais, bióticos e mecânicos na safra de 2002-2003

$\begin{array}{cccc}\text { Data de avaliação } & \text { Danos } & \text { Danos } & \text { Danos totais } \\ \text { mecânicos } \% & \text { bióticos } \% & \%\end{array}$

\begin{tabular}{lccc}
\hline $09 / 10 / 2002$ & 0,21 & 4,05 & 4,97 \\
$16 / 10 / 2002$ & 5,01 & 7,77 & 16,98 \\
$22 / 10 / 2002$ & 10,64 & 16,81 & 43,71 \\
$29 / 10 / 2002$ & 7,37 & 6,28 & 36,12 \\
$05 / 11 / 2002$ & 7,97 & 8,68 & 38,77 \\
$12 / 11 / 2002$ & 6,68 & 8,33 & 30,66 \\
$20 / 11 / 2002$ & 11,38 & 42,29 & 71,39 \\
$26 / 11 / 2002$ & 5,04 & 12,23 & 54,68 \\
\hline
\end{tabular}




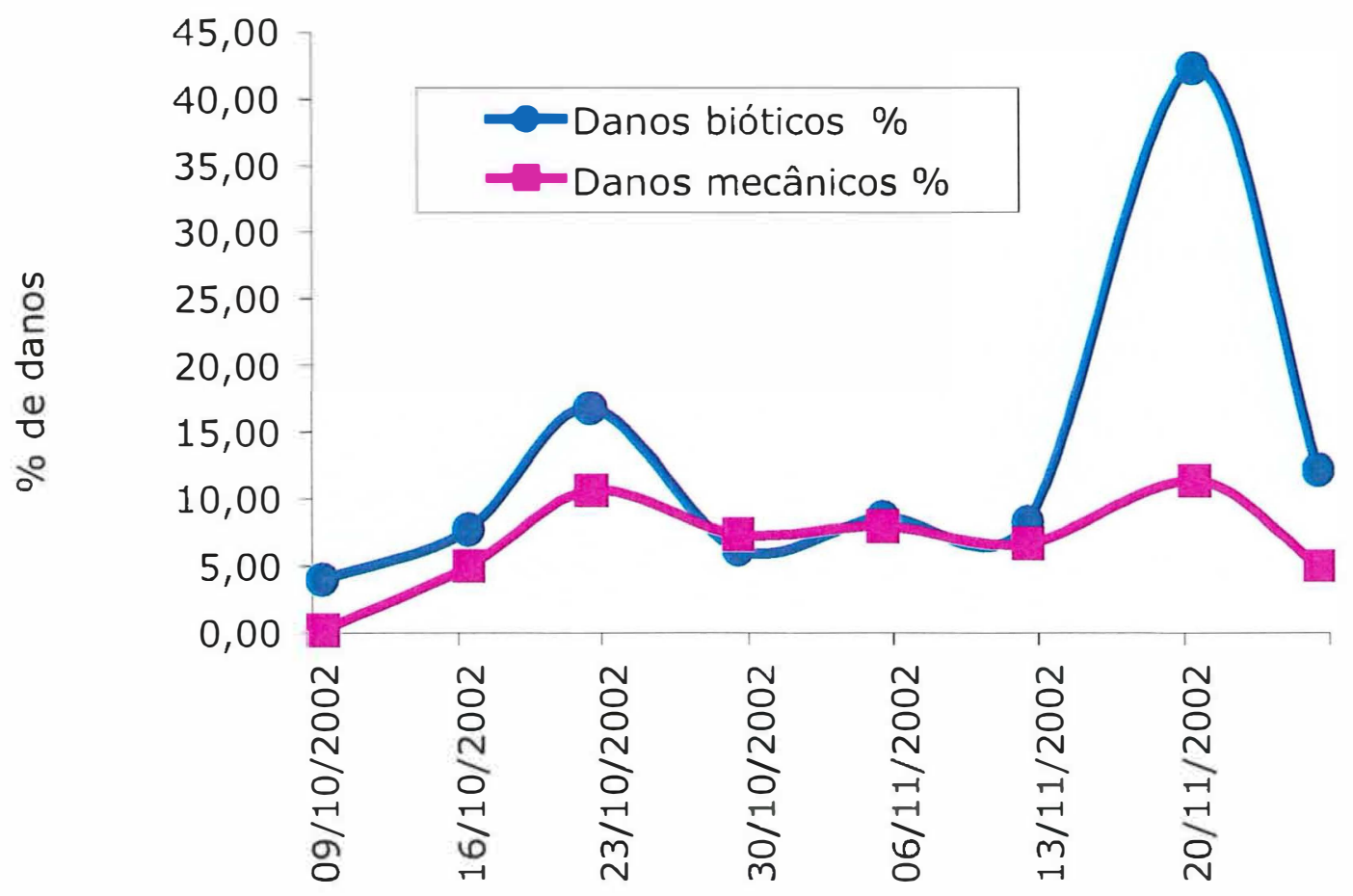

Data de avaliação

Figura 4 - Porcentagem de danos pós-colheita (bióticos e mecânicos) em pêssegos 'Aurora' na safra 2002-2003 avaliados no ETSP da CEAGESP

Os dados alarmantes da ocorrência encontrados por Eckert \& Ogawa (1988) de até 50 \% de danos pós-colheita em países em desenvolvimento, muito mais elevados que aqueles constatados em países desenvolvidos, não foram observados nos levantamentos realizados no mercado atacadista (ETSP) com o pêssego. Isto não quer dizer que os valores brasileiros sejam baixos, pois neste trabalho os danos foram avaliados em um único ponto da cadeia de produção. É preciso caracterizar, para um melhor dimensionamento do problema, o efeito dos danos pós-colheita na comercialização do 
fruto. O atacadista descarta o fruto doente, retirando-o da caixa. É preciso também quantificar o efeito do dano no valor do produto. Segundo declarações dos atacadistas, a ocorrência de qualquer início de podridão em um fruto baixa imediatamente o preço da sua unidade de venda, uma caixa de pêssego, para $60 \%$ do seu valor inicial. Ainda que o fruto podre seja descartado e que a podridão não seja aparente, o atacadista sabe que a podridão poderá aparecer em outros frutos e que o cliente reclamará e devolverá o produto, se ele for vendido pelo preço do fruto sadio.

\subsection{Conclusões}

A ocorrência de danos mecânicos no pêssego no mercado atacadista de São Paulo é muito alta, chegando a 100,00\% das caixas amostradas e $11,38 \%$ dos frutos examinados.

Existe diferença significativa de incidência de dano mecânico entre origens (produtor), mostrando que o sistema de produção e o manejo pós-colheita do pêssego, adotados pelo produtor, são determinantes na intensidade da incidência.

Existe correlação entre a freqüência de danos mecânicos e a freqüência de danos bióticos.

A ocorrência de anomalias foi menor no início da safra, quando o volume da colheita é menor e o fruto é colhido com maior firmeza de polpa. 


\section{OCORRÊNCIA DE DANOS MECÂNICOS NA PÓS-COLHEITA DE PÊSSEgo 'AURORA' - DA PLANTA AO LEILÃo DE COMERCIALIZAÇÃO}

\section{Resumo}

O valor de venda do pêssego é função da época de oferta, da variedade, da embalagem, do tamanho e aparência do fruto e da ocorrência de danos, que afetam a qualidade do fruto. Os pêssegos são frutos delicados, bastante sensíveis a danos póscolheita. A ocorrência de distúrbios pós-colheita em pêssegos frescos é uma importante causa de sua desvalorização ou rejeição na comercialização. A compreensão da ocorrência dos danos mecânicos pós-colheita do pêssego fresco, é imprescindivel para o estabelecimento de estratégias para a sua prevenção. O levantamento da ocorrência de anomalias coletadas em diferentes pontos da cadeia de produção: na planta, na sacola da colhedora, na entrada da máquina de classificação e no leilão de comercialização foi realizado na safra 2003-2004. Foram realizados 6 levantamentos semanais, de 17/10/2003 a 21/11/2003. Os danos mecânicos pós-colheita foram caracterizados pelo tipo: batida, prensado e lesão aberta e pela localização no fruto: frente (lado da sutura), verso (verso da sutura), sutura, bico, pedúnculo, fruto todo. A ocorrência total de anomalias 
cresceu com o manuseio do fruto, da colheita na planta ao leilão de comercialização. A ocorrência de dano por doença e dano mecânico pós-colheita apresentou um crescimento consistente com o aumento do manuseio do fruto. A proporção de danos mecânicos pós-colheita, aumentou $14 \%$, da planta para a sacola da colhedora, seguido por $11 \%$ da entrada para a saída da máquina de classificação. Houve diferença significativa entre os danos mecânicos avaliados: batida, prensado e lesão aberta. A batida teve o maior número de ocorrências e cresceu com o aumento do manuseio. A frente e o verso do fruto foram os locais do fruto de maior ocorrência de batida. Os locais de menor ocorrência de batida - bico, fruto todo e sutura, são os de menor ocorrência de prensado. Os pontos de coleta de maior impacto de ocorrência de batida foram a sacola da colhedora, que apresentou uma diferença de $8,50 \%$ no número de ocorrências entre a coleta na planta e a coleta na sacola da colhedora e a saída da máquina de classificação, que apresentou uma diferença de $11,70 \%$ entre o número de ocorrências entre a entrada e a saída da máquina de classificação. Estes dados mostram com muita clareza os pontos críticos de controle e onde deve haver intervenção para a melhoria do sistema de pós-colheita: a colheita e a classificação mecânica.

PAlaVRAS-ChaVe: Prunus persica L., colheita, máquina de classificação.

\section{PEACH 'AURORA' MECHANICAL POSTHARVEST DISORDERS FROM HARVEST TO PUBLIC AUCTION HOUSE}




\section{Summary}

The fresh peach value is function of the date, cultivar, size, pakaging and quality. The postharvest disorders are important in the rejection and depreciation of fresh market peach. To prevent the postharvest disorders it is necessary understand where and how they occur. The postharvest mechanical disorders survey in several points of production was made at Paranapanema municipality, state of São Paulo, responsible for $12,34 \%$ of all the fresh peach marketed at ETSP - CEAGESP. The postharvest mechanical disorders (2002-2003 harvest) were surveyed in several points of production: the plant, the harvester bag, before the packinghouse mechanical selection, after the packinghouse mechanical selectiona nd at the public auction house. There was one survey per week from October $17^{\text {th }}$ to November $21^{\text {th }}, 2003$. The mechanical disorders registered were: bruise damage, damage by compression and open damage (pulp exposure). It was also registered the location of the damage on the fruit: cheek (suture side), back (back of suture), suture, shoulder (peduncle side), tip and total fruit. The mechanical and biotic postharvest disorders have grown with handling intensity. The mechanical diosrders, were greater at the harvester bag and at the end of the packinghouse mechanical selection, and has grown $14,00 \%$ between plant and harvester bag and 11,00\% from between before and after the mechanical selection. There was significant difference between the mechanical disorders evaluated - bruise, damage by compression and open damage (pulp exposure). Bruise was the most frequent in all points and its occurrence has grown with handling 
intensity. The points at production that registered major bruise damage were the harvester bag, 8,50\% bigger than the plant, and after the mechanical selection, $11,70 \%$ bigger than immediately before the mechanical selection. The results show clearly the control critical points, the places where the damage prevention must be done: the harvest and the mechanical selection.

KEY WORDS: Prunus persica L., selection, postharvest mechanical selection, harvest.

\subsection{Introdução}

As frutas e hortaliças frescas estão cobertas por uma mistura complexa e equilibrada de bactérias, fungos e leveduras características de cada produto. A intensidade do desenvolvimento da população microbiana é função de fatores que enfraquecem ou danificam os tecidos da planta. Os patógenos vegetais com ação pectinolítica são, em geral, oportunistas e só invadem efetivamente a planta através de tecidos feridos ou senescentes. Tecidos saudáveis intactos constituem um substrato pobre para o crescimento microbiano. As condições que causam danos ao produto são as mesmas que favorecem o crescimento e o estabelecimento de altas populações microbianas (Zagory, 1999). Segundo Peleg \& Hinga (1986), 30 a 40\% das frutas e vegetais sofrem algum tipo de dano mecânico da colheita ao mercado. Pode se afirmar que a deterioração é responsável pela alta população de microorganismos e não que a alta população de microorganismos é responsável pela deterioração. A redução da injúria e a preservação da integridade fisiológica das frutas e hortaliças frescas garantem uma baixa população de 
microorganismos, e o aumento da injúria e o enfraquecimento da integridade levam a uma alta população de microorganismos (Bolin et al., 1997).

Os pêssegos são frutos delicados, bastante sensíveis a danos pós-colheita. A ocorrência de distúrbios pós-colheita em pêssegos frescos é uma importante causa de desvalorização ou rejeição do produto na comercialização. Levantamentos preliminares e o trabalho de quantificação e caracterização dos danos em pêssegos no Entreposto Terminal de São Paulo da CEAGESP, realizado na safra 2002-2003, apresentados no item 4 deste trabalho "Danos póscolheita de pêssegos no mercado atacadista", mostraram que os principais problemas pós-colheita do pêssego são os danos mecânicos e os danos bióticos. Os danos mecânicos foram mais elevados que os bióticos, quando a proporção de ocorrência de anomalias no pêssego foi muito alta, atingindo até $100 \%$ das caixas amostradas.

O desenvolvimento de uma estratégia de melhoria exige a identificação dos seus pontos críticos de controle. O objetivo do presente trabalho é identificar o momento da ocorrência do dano mecânico pós-colheita, da lavoura ao leilão de comercialização.

\subsection{Material e Métodos}

A Cooperativa Holambra II utiliza o sistema leilão reverso para comercializar os frutos dos seus cooperados e foi a primeira organização de produtores a adotar as normas de classificação do Programa Paulista para a Melhoria dos Padrões Comerciais e de Embalagens de Hortigranjeiros (1999). O município de Paranapanema é o segundo maior produtor de pêssego do Estado de São Paulo (IEA, 2004), e o segundo maior fornecedor de pêssego 
do Entreposto Terminal de São Paulo, sendo responsável pelo fornecimento de $9 \%$ de todo o pêssego comercializado na safra 20032004. O município de Paranapanema -SP foi a origem de $71,6 \%$ e a Cooperativa Holambra II de $44,70 \%$ dos lotes de pêssego vistoriados no estudo apresentado no item 4 deste trabalho "Danos pós-colheita de pêssegos no mercado atacadista". O Sr. Renato Leme, em cuja propriedade foram efetuados os levantamentos de campo, é um grande produtor de pêssego no município de Paranapanema, entrega toda sua produção para ser comercializada pela Cooperativa Holambra II, utiliza classificação mecânica, mantém registro das suas operações de produção.

Foram realizados 6 levantamentos semanais do início até o final da colheita do pêssego 'Aurora' na safra 2003-2004, nos dias: $17 / 10 / 2003,24 / 10 / 2003,31 / 10 / 2003,7 / 11 / 2003,14 / 11 / 2003$ e 21/11/2003. Em cada levantamento foram vistoriados 500 pêssegos do cultivar 'Aurora'. Os frutos avaliados em cada levantamento foram colhidos do mesmo talhão, no mesmo dia e foram coletados em 5 pontos diferentes.

$1^{\circ}$ ponto de coleta - na planta. Os frutos da amostra foram colhidos na planta, pelo próprio pesquisador, com as mãos enluvadas cuidadosamente. A indicação do fruto a ser colhido foi feita pela colhedora.

$2^{\circ}$ ponto de coleta - na sacola da colhedora. Os frutos, colhidos pela colhedora, foram colocados num saco de colheita e transportados para uma carreta, estacionada em ponto próximo do local de colheita, onde foram colocados em uma caixa plástica, despejados através da abertura do fundo do saco de colheita. Os frutos foram coletados no momento da sua colocação na caixa plástica. A amostra foi retirada 
na metade da altura do saco de colheita, suprimindo os frutos da boca e do fundo do saco de colheita.

$3^{\circ}$ ponto de coleta - na entrada da máquina de classificação. Depois da colocação na caixa de colheita, os frutos são transportados por uma carreta puxada por um trator até a entrada da casa de embalagem. As caixas plásticas são descarregadas e empilhadas próximas à máquina de classificação, uma a uma. Elas são rapidamente retiradas da pilha e encaixadas num mecanismo que garante uma descarga lenta dos frutos na esteira inicial da máquina de classificação. A amostra foi retirada entre os frutos do meio das caixas plásticas imediatamente antes da sua colocação na máquina de classificação.

$4^{\circ}$ ponto de coleta - na saída da máquina de classificação, depois do processo de classificação mecânica por rolete e do embalamento e antes do seu empilhamento paletizado e colocação no caminhão para envio ao leilão. A amostra foi uma caixa de comercialização (caixa de papelão aberta de $4 \mathrm{~kg}$ ) pronta para ser enviada ao leilão.

$5^{\circ}$ ponto de coleta - no leilão de comercialização. Depois de passar pela máquina de classificação e pelo embalamento, os frutos em suas caixas de comercialização, foram empilhados, paletizados, colocados em caminhão aberto e transportados para o barracão de leilão de comercialização, distante 10 quilômetros, com pequeno trecho $(1,5$ $\mathrm{km}$ ) de estrada de terra. No barracão de leilão, foram descarregados por uma máquina hidráulica de descarga paletizada. Uma caixa foi retirada como amostra, logo após a descarga no barracão de leilão.

A figura 6 ilustra a prática do produtor em cada ponto de coleta. A colheita do pêssego começava às 7 horas da manhã e às 14 horas o fruto já havia sido descarregado no recinto do leilão. Em 
cada ponto de coleta foram vistoriados 100 frutos em cada uma das 6 datas de levantamento, em 5 pontos de coleta, totalizando 3000 frutos, ao final do experimento. No momento da coleta em todos os pontos, os frutos foram manuseados com mão enluvada, com todo cuidado (Figura 6), e colocados em bandejas individualizadas em uma camada em caixas de papelão abertas. No dia seguinte à coleta do fruto foi feita a primeira avaliação, que identificou o tipo da anomalia e a sua localização no fruto.

As anomalias foram divididas em grupos: dano fisiológico, dano por praga, lesão cicatrizada, dano mecânico póscolheita, dano por doença. O fruto foi dividido em partes (Figura 5) para a localização do dano: bico, pedúnculo, sutura, frente (lado do fruto onde está a sutura), verso (lado do fruto oposto à sutura) e fruto todo. Foram considerados como danos mecânicos pós-colheita: batida, prensado e lesão aberta (Figura 7). As comparações da incidência de danos por ponto de coleta, por tipo de dano mecânico e da localização do dano no fruto foram feitas pelo teste $F$, considerando cada data de levantamento como uma repetição. Os conceitos estabelecidos no Regulamento Técnico de Identidade e Qualidade do Pêssego proposto por Gutierrez (2004), foram utilizados neste trabalho. Defeito ou dano ou anomalia: toda e qualquer alteração do fruto causada por fatores de natureza fisiológica, mecânica ou por agentes diversos, que comprometam a qualidade do fruto. Podridão: dano patológico visível por decomposição, desintegração ou fermentação dos tecidos. Dano profundo ou lesão aberta: qualquer lesão, não importando a sua causa, que rompa a epiderme, expondo a polpa do fruto. Amassado ou batida: alteração da polpa sem ruptura da epiderme, com escurecimento enzimático 
interno e deformação, visiveis externamente. Dano cicatrizado ou lesão cicatrizada: todas as lesões que embora tenham rompido a epiderme, estão cicatrizadas e não expõem a polpa, mas alteram a firmeza de polpa e o formato da superfície do fruto. O dano caracterizado como prensado foi introduzido neste trabalho para identificar o dano por compressão, que normalmente ocorre quando o fruto é comprimido sobre uma superfície mais estreita que ele, como a lateral de uma caixa e que gera uma marca bem característica na superfície do fruto (Figura 7).

O estádio de maturação dos frutos na colheita foi avaliado pela medida da firmeza da polpa de 10 frutos semanalmente. Foram feitas duas leituras por fruto, com o auxílio de um penetrômetro Magness - Taylor, ponta de $8 \mathrm{~mm}$, em lados opostos de sua região equatorial, de onde previamente, foi retirada a epiderme. Os dados foram expressos em Newton $(N)$, considerando-se a média das duas leituras.

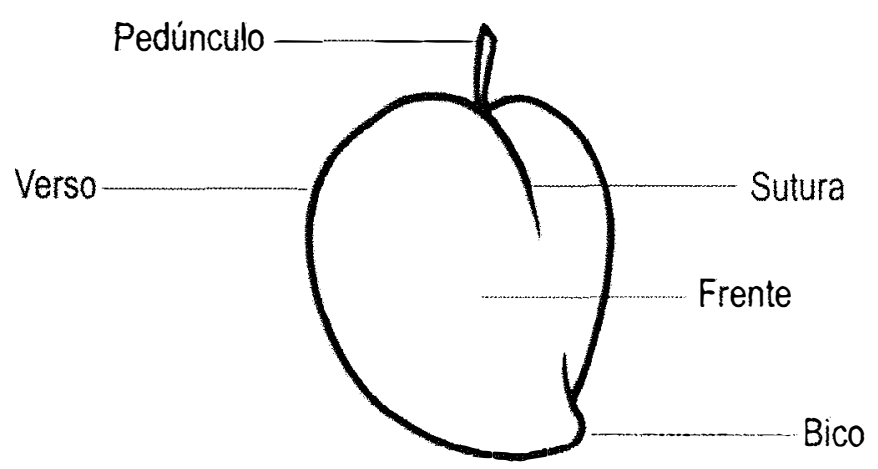

Figura 5 - Pontos de localização do dano no fruto 


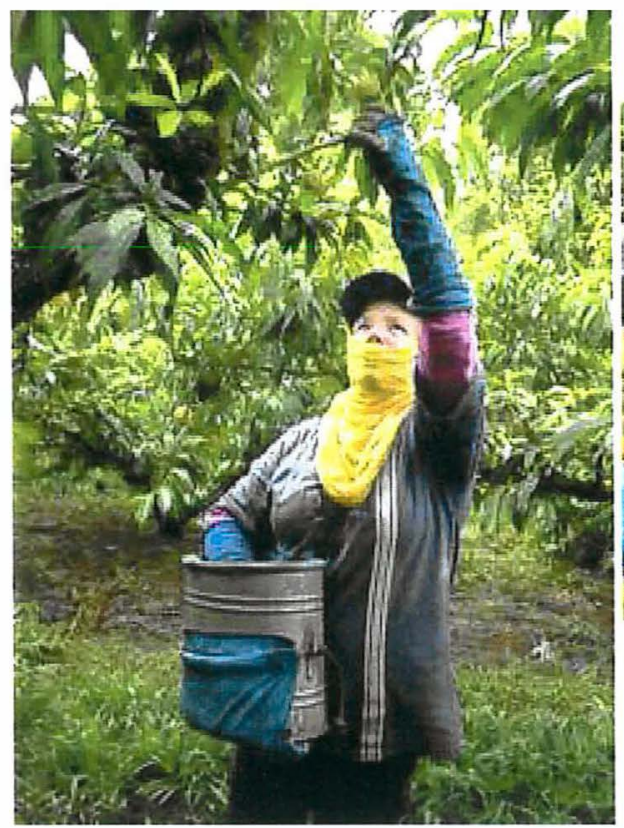

Coleta na planta

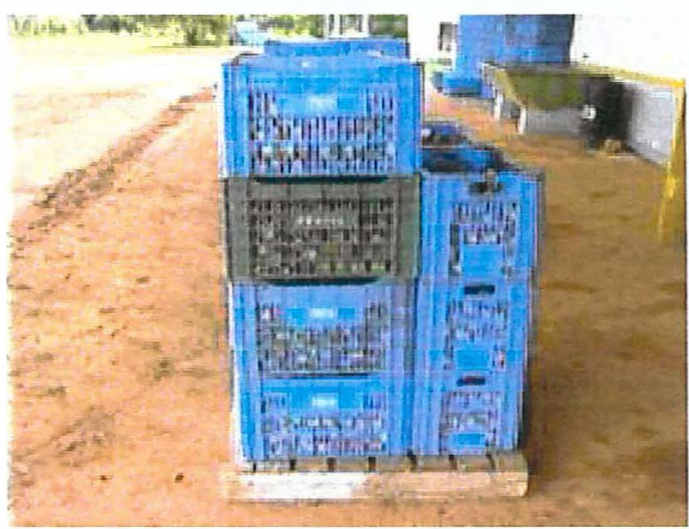

Coleta na entrada da máquina de classificação

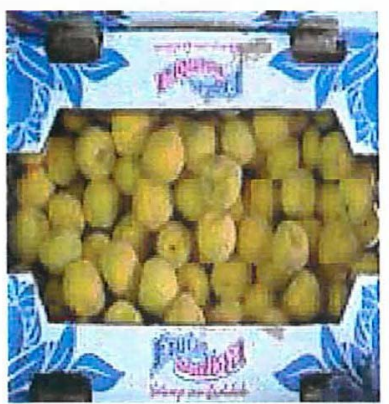

Coleta no leilão

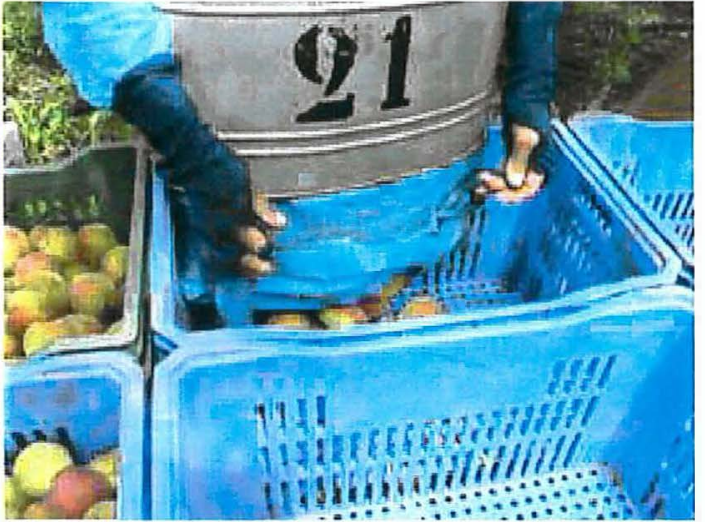

Coleta na sacola da colhedora

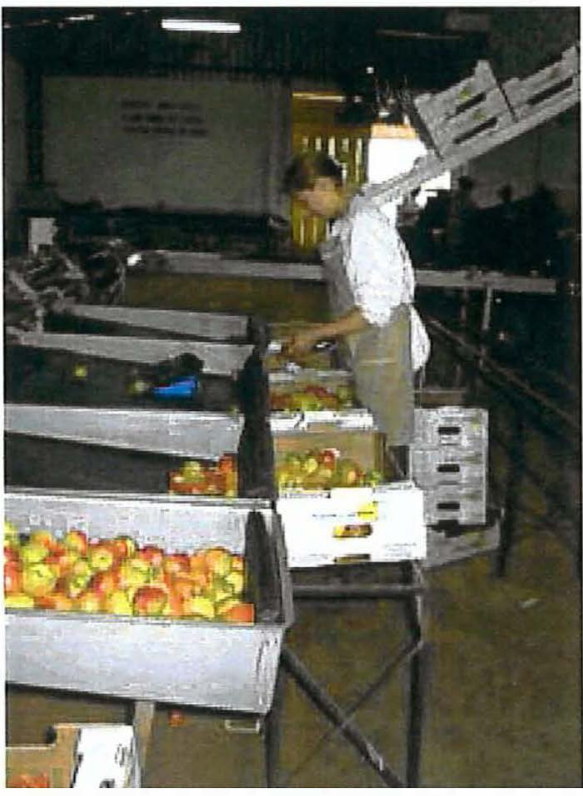

Coleta na saída da máquina de classificação

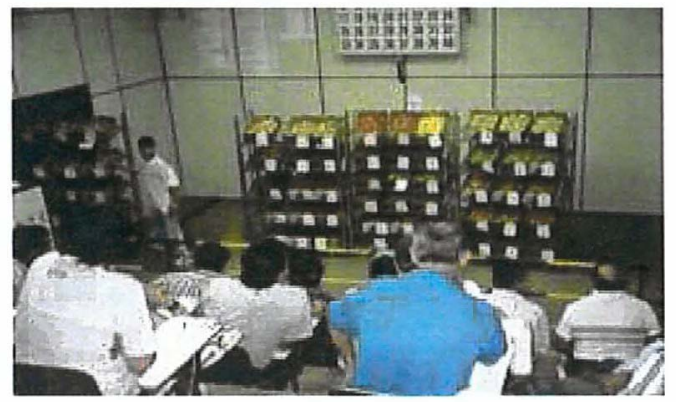

Figura 6 - Prática do produtor em cada ponto de coleta 

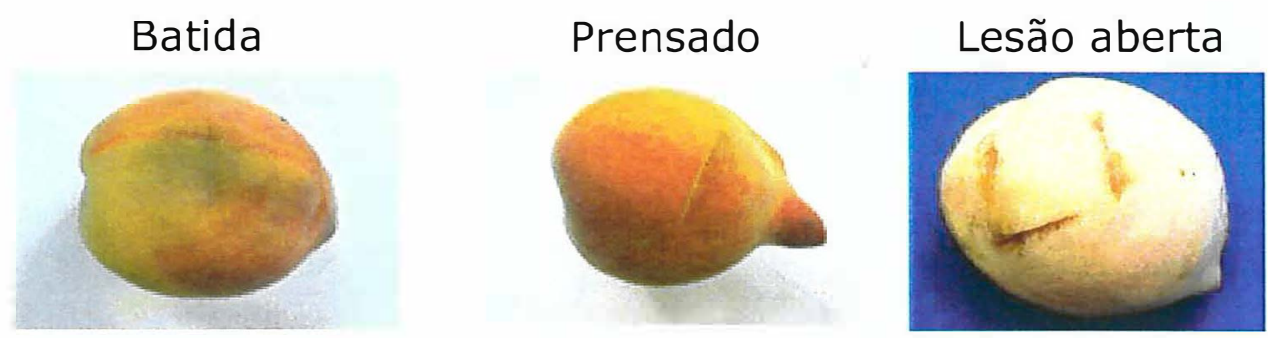

Danos mecânicos pós-colheita
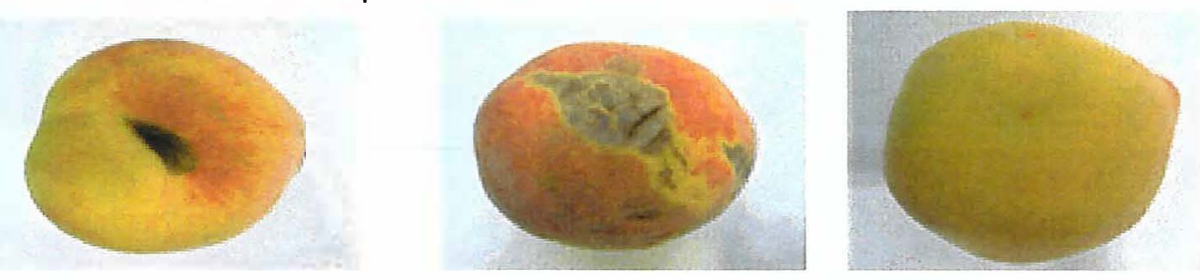

Danos fisiológicos
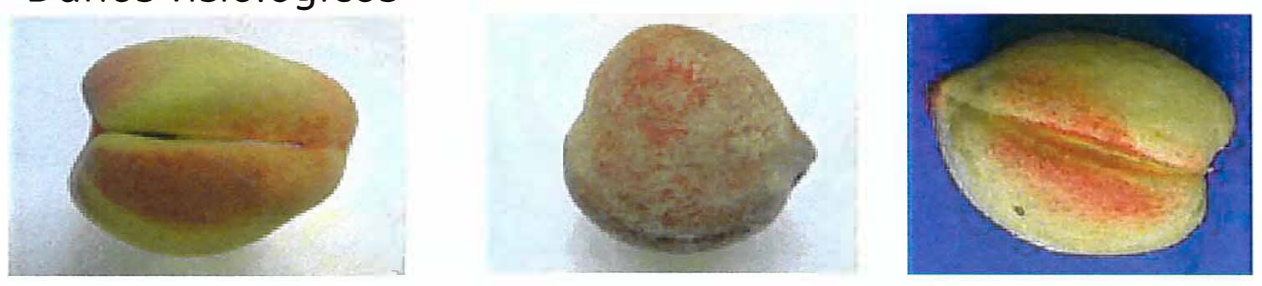

\section{Pragas}
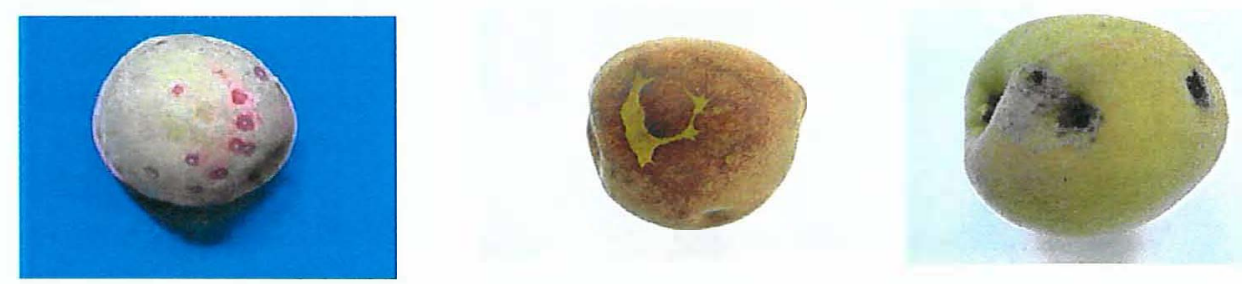

Podridões
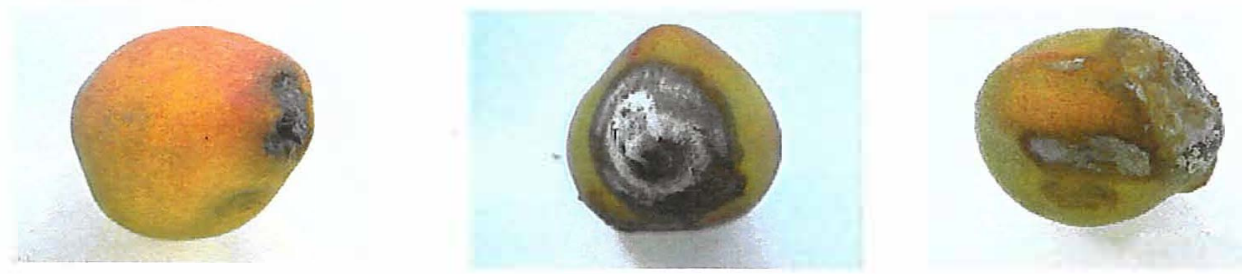

Figura 7 - Danos pós-colheita em pêssegos 


\subsection{Resultados e Discussão}

A ocorrência de anomalias cresceu com o manuseio do fruto, da colheita na planta ao leilão de comercialização. A firmeza média da polpa variou de $40 \mathrm{~N}$ na $1^{\text {a }}$ semana para $30 \mathrm{~N}$ na última semana.

O perfil da ocorrência variou com o grupo de anomalia. A lesão cicatrizada, o dano por praga e o dano fisiológico não evoluíram com o manuseio. O dano por doença e o dano mecânico pós-colheita apresentaram uma evolução consistente com o manuseio. É muito visível o aumento do número de ocorrências do dano mecânico pós-colheita e do dano por doença com o manuseio (Tabela 15). A proporção de danos mecânicos pós-colheita, foi de 0,08 para $0,22(14 \%)$, da planta para a sacola da colhedora, seguido pela variação de 0,28 para $0,39(11 \%)$ da entrada para a saída da máquina de classificação (Tabela 15). Entre a colhedora e a entrada do barracão e houve um aumento na proporção de danos mecânicos menor, de 0,22 para 0,28 (6\%). A figura 10 mostra que a evolução dos danos mecânicos é bastante similar à dos danos por doença. A elevada incidência de doenças é decorrência de injúrias mecânicas provocadas nos frutos, nas diferentes etapas pós-colheita, que servem de porta de entrada para os patógenos. Existe correlação positiva entre os danos mecânicos e os danos por doença $\left(R^{2}=0,97\right)$. 
Tabela 15. Porcentagem de anomalias em pêssegos 'Aurora' em função do ponto de coleta. Resultados expressos em porcentagem entre o número de frutos com anomalia e $o$ número total de frutos avaliados

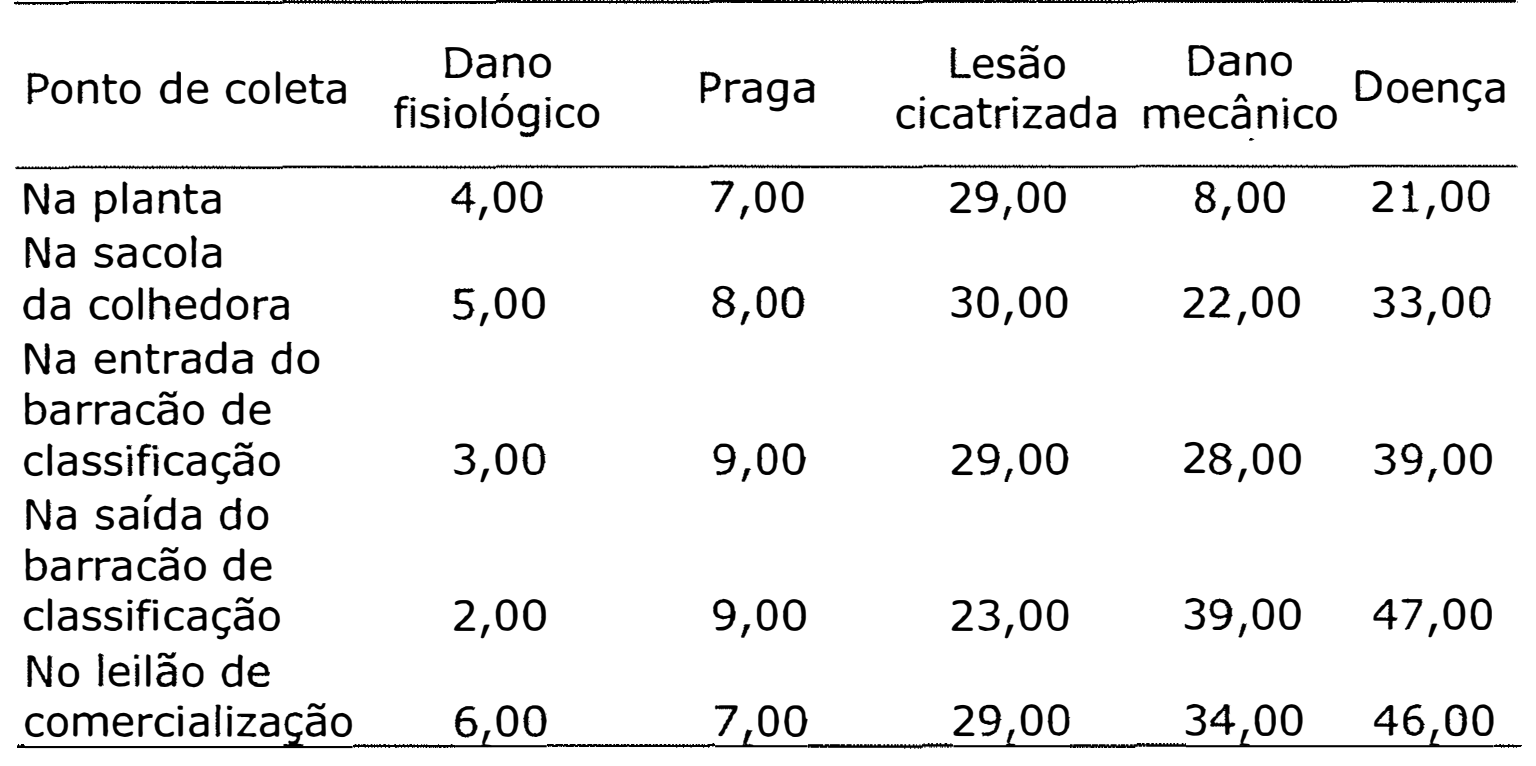

Os frutos batidos, prensados e com lesão aberta, foram levantados separadamente. A batida foi a anomalia de maior porcentagem de ocorrência e seu número cresceu com o manuseio (Tabela 16). Houve diferença significativa entre os pontos de coleta para os frutos batidos, prensados e com lesão aberta. A saída da máquina de classificação foi o ponto de coleta com maior ocorrência de batidas. Foi também o segundo ponto de maior ocorrência do fruto prensado, depois do leilão. A maior ocorrência de lesão aberta foi registrada na entrada do barracão de classificação leilão, seguida pela saída da máquina de classificação e pela sacola de colhedora (Tabela 16). A ocorrência de danos em cada ponto deve ter sido afetada pelo processo de retirada de frutos com danos mais visíveis durante a classificação. Na entrada da máquina de classificação os frutos com 
defeitos muito evidentes são retirados manualmente. $O$ fruto prensado ocorreu com mais freqüência no leilão, provavelmente porque uma de suas maiores causas é a pressão da caixa sobre o fruto e o leilão foi o ponto de coleta em que a fruta permaneceu mais tempo embalada. O número de ocorrências de batidas foi maior na sacola da colhedora que apresentou uma diferença de $8,50 \%$ para o ponto de coleta anterior - a planta e na saída da máquina de classificação apresentou uma diferença de $11,70 \%$ para o ponto de coleta anterior (Tabela 16). Na colheita do fruto, a colhedora manuseia cada fruto e o coloca num saco de colheita que tem um fundo que precisa ser aberto no momento da descarga dos frutos na caixa plástica de colheita. A equipe de colheita tem um chefe, que exige cuidados na escolha do fruto, no manuseio e na descarga do fruto da sacola para as caixas de colheita. Não existe exigência sobre corte ou limpeza das unhas da colhedora. A maioria das colhedoras usa uma proteção na mão que deixa os dedos fora. A máquina de classificação é mecânica e atinge impactos, medidos com a esfera instrumentada da Techmark, por Ferreira (2003) até $153 \mathrm{G}$ $\left(\mathrm{G}=9,807 \mathrm{~m} / \mathrm{s}^{2}\right)$. 
Tabela 16. Porcentagem de pêssegos 'Aurora', com danos mecânicos, com batida, prensado e com lesão aberta, em função do ponto de coleta

\begin{tabular}{lccc}
\hline \multicolumn{1}{c}{ Ponto de coleta } & Batida & Prensado & aberta \\
\hline Na planta & $5,00 \mathrm{e}$ & $0,00 \mathrm{~d}$ & $2,00 \mathrm{~b}$ \\
Na sacola da colhedora & $13,50 \mathrm{~d}$ & $6,17 \mathrm{~b}$ & $2,17 \mathrm{~b}$ \\
Na entrada do barracão de classificação & $19,00 \mathrm{c}$ & $3,83 \mathrm{c}$ & $4,67 \mathrm{a}$ \\
Na saída do barracão de classificação & $30,17 \mathrm{a}$ & $6,17 \mathrm{~b}$ & $2,17 \mathrm{~b}$ \\
No leilão de comercialização & $24,87 \mathrm{~b}$ & $7,33 \mathrm{a}$ & $0,67 \mathrm{c}$ \\
\hline
\end{tabular}
As diferenças foram significativas para letras diferentes $(a<0,05)$ pelo teste $\mathrm{F}$.

Os resultados mostram com muita clareza os pontos críticos de controle e onde deve haver intervenção para a melhoria do sistema de pós-colheita: a classificação mecânica e a colheita.

Houve um aumento consistente de ocorrência de batidas com 0 aumento do manuseio, o que não aconteceu na ocorrência de lesão aberta e fruto prensado. Houve diferença significativa (Tabela 17) na localização do dano mecânico pós-colheita no fruto. Em todos os pontos de coleta, a frente do fruto foi o local mais atingido, seguida pelo verso do fruto. Os locais de maior ocorrência de batida no fruto (bico, fruto todo e sutura) são os de menor ocorrência de fruto prensado (pedúnculo, frente e verso) (Tabela 18). A ocorrência de frutos batidos está relacionada à seleção manual na máquina de classificação, à movimentação do fruto na máquina de classificação e ao manuseio na colheita. A ocorrência de frutos prensados está relacionada ao fruto numa posição de repouso em contato com uma superfície mais dura e mais estreita que o fruto. 
Tabela 17. Porcentagem total de danos mecânicos pós-colheita em pêssego 'Aurora' em função do local do fruto

Local do fruto

Média de ocorrências

Bico $7,00 \mathrm{~b}$

Frente

Fruto todo

$22,00 \mathrm{a}$

Pedúnculo

$2,50 \mathrm{c}$

Sutura

$5,67 \mathrm{~b}$

Verso

$2,67 \mathrm{c}$

As diferenças foram significativas para letras diferentes $(a<0,05)$ pelo teste $F$.

Tabela 18. Porcentagem de ocorrência do dano, em função da localização no fruto, em frutos batidos, prensados e com lesão aberta

\begin{tabular}{lccc}
\hline \multicolumn{1}{c}{ Local do fruto } & Batidos & Lesão aberta & Prensados \\
\hline Bico & 69,05 & 23,81 & 7,14 \\
Frente & 53,03 & 12,88 & 34,09 \\
Fruto todo & 93,33 & 0,00 & 6,67 \\
Pedúnculo & 41,18 & 20,59 & 38,24 \\
Sutura & 75,00 & 18,75 & 6,25 \\
Verso & 59,78 & 10,78 & 29,35 \\
\hline
\end{tabular}

\subsection{Conclusões}

A ocorrência de anomalias cresce consistentemente em cada elo da cadeia de produção. As anomalias desenvolvidas durante o processo de produção do fruto - lesão cicatrizada, dano por praga e dano fisiológico - não evoluem com o aumento do manuseio na cadeia. A ocorrência de dano por doença e de dano mecânico póscolheita evoluem com o aumento do manuseio do fruto e apresentam uma relação linear positiva e significativa. 
A frente e o verso do fruto são os pontos de maior ocorrência dos danos mecânicos pós-colheita.

Os pontos críticos de controle, onde deve ser priorizada a intervenção para a melhoria do sistema de pós-colheita são a classificação mecânica e a colheita. 


\section{EFEITO DO IMPACTO NA QUALIDADE E NO METABOLISMO DO PÊSSEGO}

\section{Resumo}

Pêssegos são frutos delicados e muito sensíveis a injúrias pós-colheita. O pêssego 'Aurora' é um dos cultivares mais plantados no estado de São Paulo e é conhecido como um pêssego resistente ao manuseio. Pêssegos 'Aurora', colhidos no início da safra de 2004, foram submetidos ao impacto de queda sobre uma chapa de aço em 3 alturas: 5, 10 e $15 \mathrm{~cm}$, em dois ensaios. No primeiro ensaio foram avaliados: o efeito visual do impacto, a firmeza da polpa, a cor de fundo, a acidez, o teor de sólidos solúveis e a perda de massa fresca, em duas épocas: dois e quatro dias após o impacto. No segundo ensaio foram avaliados: o efeito visual do impacto, a produção de etileno, a intensidade da respiração, através da produção de $\mathrm{CO}_{2}$, e a perda de massa fresca. A firmeza da polpa, as cores de fundo $L^{*}$ e $\mathrm{H}^{*}$ evoluíram com a época, mudanças características do processo de amadurecimento. O teor de sólidos solúveis, a firmeza da polpa e as cores de fundo $\mathrm{C}^{*}$ e $\mathrm{h}$ não registraram o efeito do impacto. efeito do impacto foi registrado pela perda percentual de massa fresca, acidez, "ratio", cor de fundo L*, intensidade de respiração e comportamento da produção inicial de etileno. A maior 
diferença foi observada entre as alturas de impacto 5 e $15 \mathrm{~cm}$. A variação da massa fresca foi a única medida que registrou o efeito do impacto de $5 \mathrm{~cm}$ de altura, comparado ao tratamento sem impacto e revelou-se uma medida de aplicação simples e barata e, embora seja atualmente pouco utilizada na avaliação da qualidade de frutos, apresenta potencial revelador de problemas de qualidade semelhante ao demonstrado por processos mais complexos e caros, como os de avaliação da intensidade de respiração.

PALAVRAS-ChaVe: Prunus persica L., etileno, respiração, massa fresca.

\section{IMPACT EFFECTS ON PEACH QUALITY AND METABOLISM}

\section{Summary}

Peaches are fragile fruits, very suscetible to post harvest disorders. The 'Aurora', the fresh peach variety more planted at State of Sao Paulo, is known as resistent to handling. A laboratory test has measured the quality and metabolic effects of impact in fresh market peach 'Aurora' (2003-2004 harvest). The impact damage simulation was made at the beginning of the harvest and in all tested drop heights: 5,10 and $15 \mathrm{~cm}$ there were not visible bruise damages. The peaches have shown, in two and four days after harvest day, quality changes, on ground color, fresh matter loss, acidity, "ratio" and soluble solids content. The effect of impact on fruit metabolism was measured by fresh matter loss, respiration intensity $\left(\mathrm{CO}_{2}\right.$ production) and ethylene production. Flesh firmness, ground color $L^{*}$ and $h$ has changed with time, a behaviour expected, proper of maturation. 
Soluble solids content, flesh firmness and ground color $C^{*}$ and $\mathrm{h}$ have not changed with the impact. The impact effect was registered on fruit quality and metabolism by the variables: fresh matter loss, $\mathrm{CO}_{2}$ production (respiration intensity) and first production of ethylene. Difference was significant between 5 and $15 \mathrm{~cm}$ drop height. The fresh matter loss was the only variable that registered the impact effect of $5 \mathrm{~cm}$ drop, when compared to no drop.

KEY WORDS: Prunus persica L., ethylene, respiration, fresh matter.

\subsection{Introdução}

Os pêssegos são frutos delicados, bastante sensíveis a injúrias pós-colheita. Levantamentos preliminares de danos póscolheita no pêssego, realizados no Entreposto Terminal de São Paulo da CEAGESP, mostraram que os danos mecânicos foram os responsáveis por $48,50 \%$ dos danos totais encontrados nos 5506 lotes de pêssego vistoriados nas safras de pêssego de 1999 a 2001.

Os resultados do ensaio aqui apresentados "Ocorrência de danos mecânicos na pós-colheita de pêssego 'Aurora' - da planta ao leilão de comercialização" mostram a batida como a anomalia de maior ocorrência. Foi constatada diferença de 8,50\% na ocorrência de batidas entre a coleta do fruto na planta e na sacola da colhedora e de $11,70 \%$ entre a entrada e a saída da máquina de classificação. A ocorrência média de danos mecânicos foi de $8,00 \%$ na planta, chegando a $38,00 \%$ na saída da máquina de classificação, locais onde a ocorrência de batida foi de 5,00\% chegando a 24,87\% .

O dano por impacto geralmente é causado pela colisão do fruto contra superfícies sólidas ou outros frutos durante as etapas 
de colheita, manuseio e transporte (Mohsenin, 1986). O dano mecânico por compressão é causado pela imposição de uma pressão variável contra a superfície externa do fruto, quer seja por um fruto adjacente ou pela própria parede da embalagem, em que está acondicionado o fruto. O dano por corte é geralmente atribuído à colisão da superfície do fruto contra outra superfície muito menor, ocasionando a ruptura da epiderme, ou pela imposição de uma pressão sobre o fruto contra superfícies também desiguais, como as arestas de uma embalagem (Mattiuz, 2002). Segundo Mattiuz (2002) o dano por impacto gerou maior intensidade de respiração e maior produção de etileno em goiabas Paluma e Pedro Sato, do que o dano por compressão e corte. O estudo de Kasat (2004) avaliou o efeito dos danos mecânicas na qualidade pós-colheita de pêssegos 'Aurora $1^{\prime}$ e também mostrou um efeito maior do dano por impacto, que por compressão e corte.

Na maioria dos estudos sobre o efeito do impacto no pêssego, o dano é caracterizado pela ocorrência de uma porção mais translúcida que o tecido ao redor (Berardinelli et al., 2001), resultando em pontos encharcados na polpa do fruto. A sensibilidade ao impacto é medida pelo tamanho do defeito visível, resultado da força aplicada no local ou de queda livre, em diferentes alturas, sobre diferentes superfícies (Garcia et al. 1988 e Brusewitz \& Bartz, 1989). A visibilidade da batida acontece quando ocorre uma fratura do tecido, sob a epiderme (Schulte et al., 1994). Grande parte dos estudos de impacto não avalia o efeito do impacto no metabolismo do fruto.

O objetivo do presente trabalho é determinar o efeito do impacto na qualidade e no metabolismo do pêssego. 


\subsection{Material e Métodos}

Pêssegos 'Aurora' foram colhidos às 8 horas da manhã, do dia 20 de setembro de 2004, no início da safra de pêssego, na propriedade do Sr. Norival Gallo, Sítio Irmãos Gallo, no Bairro Maracanã do município de Atibaia, estado de São Paulo. Foram colhidos com cuidado e colocados em bandejas com alvéolos individuais, em uma camada única, dentro de caixas de papelão. 0 fruto foi colhido com cor de fundo, no mínimo, verde-amarelada, dentro dos critérios de ponto de colheita utilizados pelo produtor. Imediatamente após a colheita, os frutos foram transportados para o Laboratório de Pós-Colheita do Departamento de Produção Vegetal da ESALQ, e lá chegaram às 10 horas da manhã.

Imediatamente após a chegada ao laboratório de póscolheita, foi efetuada uma pré-seleção dos frutos, retirando aqueles com defeitos e uniformizando-os quanto ao grau de maturação (cor de fundo) e tamanho. Do total de frutos selecionados foram retiradas amostras aleatórias para a caracterização do lote e os dois ensaios de avaliação de impacto.

Para avaliar o efeito de impactos sobre os frutos, foram efetuados dois ensaios: 1) Efeito do impacto no metabolismo do fruto; 2) Efeito do impacto na qualidade do fruto.

Para a caracterização do lote foi tomada uma amostra de 50 frutos e foram efetuadas medições por fruto ( $n=50$ frutos) ou por repetição (5 repetições de 10 frutos), dependendo da variável. As medições por fruto foram firmeza da polpa e cor de fundo e por 
repetição foram massa fresca ( $g$ ), teor de sólidos solúveis ( ${ }^{\circ}$ Brix) e acidez titulável ( $\mathrm{g}$ de ácido málico / $100 \mathrm{~g}$ do fruto).

A determinação da firmeza da polpa na porção mediana do fruto foi feita com o penetrômetro digital 53200 marca Samar Tr. Turoni, com ponteira de $8 \mathrm{~mm}$ de diâmetro e expressa em Newton.

A determinação, da cor de fundo ou da epiderme, foi efetuada com o colorímetro Minolta CR-300, tomando-se uma leitura por fruto, no local da epiderme do fruto onde a cor de fundo fosse bem visível, isento do recobrimento avermelhado. Os resultados foram expressos em L* (luminosidade), $C^{*}$ (cromaticidade) e $\mathrm{h}$ (ângulo de cor).

A massa fresca foi determinada, por pesagem dos frutos de cada repetição, em balança Digipeso DP-3000, com precisão de um grama.

O teor de sólidos solúveis totais foi determinado utilizando-se um refratômetro ótico digital, marca Atago PR-101, com precisão de $0,1 \circ$ Brix, no suco extraído por centrifugação dos frutos descascados de cada repetição. A acidez total titulável (AT) foi determinada no suco, extraído por centrifugação, diluído com água na proporção 1:9 (v:v), com a utilização de $\mathrm{NaOH}$ a $0,1 \mathrm{~N}$, no peagâmetro e é expressa em gramas de ácido málico por 100 gramas de polpa. A partir das determinações do teor de sólidos solúveis e da acidez titulável, foi calculada a relação teor de sólidos solúveis pela acidez, conhecida como "ratio".

Os tratamentos consistiram de simulações de batidas (impactos) nos frutos, em diferentes intensidades, efetuadas com auxílio de um instrumental adaptado (Figura 8), construído com um aspirador de pó para suç̧ão, uma ventosa para a fixação do fruto, 
uma haste de regulagem de altura e uma chapa de metal. A regulagem da altura foi feita de maneira a proporcionar a queda livre nas alturas de $5 \mathrm{~cm}, 10 \mathrm{~cm}$ e $15 \mathrm{~cm}$ da parte inferior do fruto até uma chapa metálica. As alturas de queda foram estabelecidas com base em medidas realizadas com a esfera instrumentada da Techmark Inc. no mesmo instrumental de impacto, utilizando diferentes alturas de impacto, de maneira a reproduzir o impacto registrado pela esfera instrumentada na máquina de classificação da Fazenda Capuava, do Sr. Renato Leme, na safra de 2.003 (Ferreira, 2003), onde foi realizado o estudo "Ocorrência de danos mecânicos pós-colheita - da planta ao leilão de comercialização". O maior impacto registrado pela esfera instrumentada na máquina de classificação foi de 125 G ( $G$ = $9,81 \mathrm{~m} / \mathrm{s}^{2}$ ). O impacto médio, registrado pela esfera instrumentada (Techmark, Lansing Michigan, diâmetro de 70 mm e massa de 165 gramas (Techmark, 2004)), em placa de aço, em laboratório, a $10 \mathrm{~cm}$ de altura foi $153 \mathrm{G}$ e a $5 \mathrm{~cm}$ de altura 69,53 G (Ferreira, 2004). Com o aumento da altura do impacto o valor de $G$ sobe e o valor de $G$ por cm desce (Figura 9). 


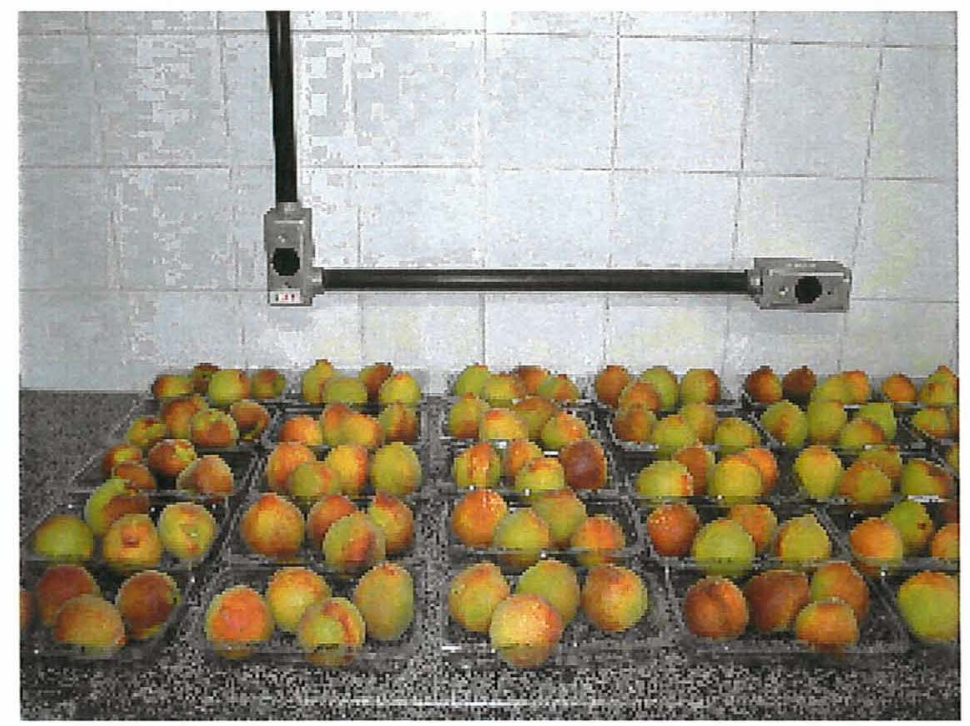

Frutos antes da aplicação do impacto

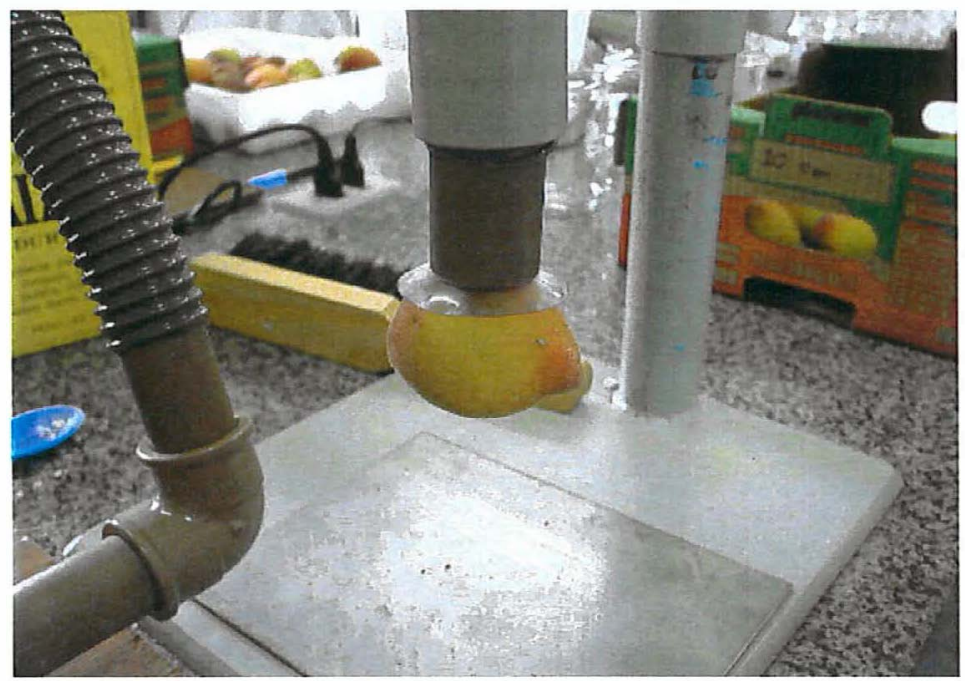

Aplicação do impacto

Figura 8 - Pêssegos 'Aurora' antes e durante a aplicação do impacto 


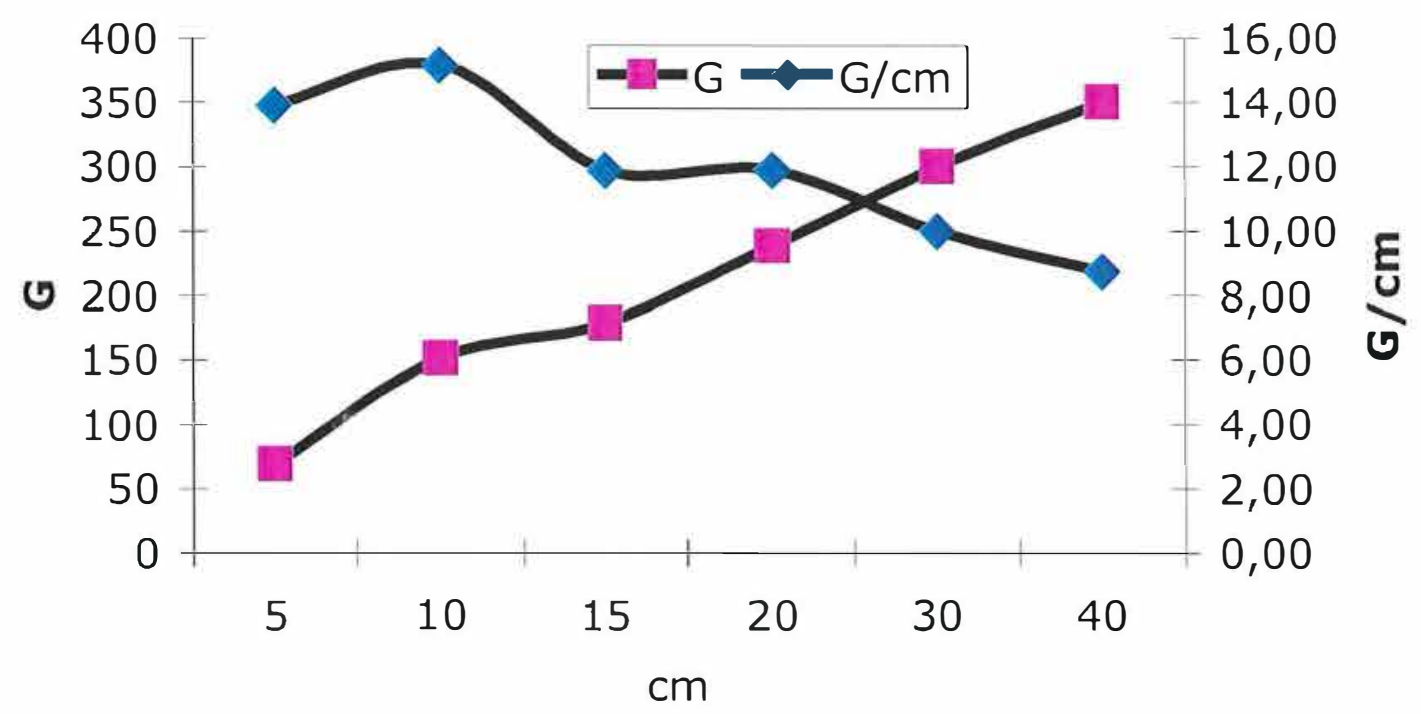

Figura 9 - Força de impacto registrada pela esfera instrumentada submetida a quedas de diferentes alturas sobre uma placa de aço (Ferreira, 2004)

Para o ensaio de avaliação do efeito do impacto no metabolismo do fruto foi tomada uma amostra de 72 frutos, sendo 18 frutos por tratamento ( 6 repetições, com 3 frutos por repetição). Os frutos foram colocados em recipientes de vidro herméticos, com massa e volume conhecidos. A primeira leitura foi feita uma hora após a instalação do ensaio, e as outras, a cada 24 horas, num total de 6 leituras, da massa fresca (g), liberação de etileno (em $\mathrm{ml} \mathrm{C}_{2} \mathrm{H}_{4} \mathrm{Kg}^{-1} \mathrm{~h}^{-1}$ ) e da respiração (produção de $\mathrm{CO}_{2}$ em $\mathrm{ml} \mathrm{CO}_{2} \mathrm{Kg}^{-1} \mathrm{~h}^{-1}$ ).

Para o ensaio de qualidade (Efeito do impacto no fruto após 2 dias e 4 dias) foi tomada uma amostra de 160 frutos, 40 frutos 
por tratamento, 5 repetições, com 4 frutos por repetição e 2 e 4 dias após a produção do impacto.

Os ensaios foram conduzidos segundo o delineamento inteiramente ao acaso. Os tratamentos foram as diferentes alturas testadas para causar impacto e a ausência de impacto (Altura $0 \mathrm{~cm}$ testemunha).

As amostras correspondentes às repetições dos tratamentos no ensaio de qualidade foram avaliadas 2 e 4 dias após a aplicação dos tratamentos, resultando em um ensaio com dois fatores - altura e época de avaliação - analisado em parcelas subdivididas.

O esquema de parcelas subdivididas no tempo foi utilizado no ensaio de avaliação do metabolismo.

Para os desdobramentos das análises de variâncias, conforme a significância do teste $F$, foi utilizado o teste de Tukey para os efeitos de altura e de época de avaliação e análise de regressão linear para o efeito de leituras no ensaio de avaliação de alterações no metabolismo do fruto.

Algumas medidas calculadas a partir dos dados originais foram utilizadas na análise: a perda percentual de massa fresca, a perda percentual de massa fresca por centímetro de altura de impacto e a produção acumulada de $\mathrm{CO}^{2}$. A perda de massa fresca em gramas foi transformada em perda percentual de massa fresca para eliminar as diferenças iniciais de massa fresca entre os frutos e foi calculada pela diferença percentual com a primeira medida de massa fresca. A perda de massa fresca por centímetro foi calculada através da divisão da perda percentual de massa fresca pelo número de centímetros da altura de impacto a que foi submetido o fruto. A 
produção acumulada de $\mathrm{CO}_{2}$ foi calculada pela soma em cada leitura das leituras anteriores.

\subsection{Resultados e Discussão}

O registro do impacto pela esfera instrumentada é um parâmetro mensurável de comparação, mas não traduz, com exatidão, o efeito do impacto no pêssego, formado por um tecido denso, cheio de suco e baixa porcentagem de espaço intersticial cheio de ar (Maness et al., 1992). O efeito do impacto (Ogut et al.1999), depende da elasticidade do produto, ou seja a sua capacidade de se recuperar de deformação. A boa absorção do impacto do pêssego foi bem demonstrada por Crisosto et al. (2000), pela diferença encontrada entre os impactos registrados pela esfera instrumentada, em queda sobre um fruto de pêssego e sobre uma chapa de aço. 0 impacto sobre chapa de aço, em queda livre de $1 \mathrm{~cm}$ de altura, foi semelhante ao impacto da esfera instrumentada, sobre um fruto de pêssego, em queda livre de $60 \mathrm{~cm}$.

Os frutos utilizados no presente ensaio apresentaram a polpa firme, teor de sólidos solúveis próximo a $8^{\circ}$ Brix e cor de fundo verde-amarelada (Tabela 19) obedecendo às exigências mínimas de maturação do fruto na colheita estabelecidas pela norma de classificação de pêssego e nectarina do Programa Paulista para a Melhoria dos Padrões Comerciais e de Embalagens de Hortigranjeiros (1999) e da Comissão das Comunidades Européias (1999). 
Tabela 19. Caracterização físico-química do pêssego recém colhido

Característica

Estimativa (95\% de confiança)

Massa fresca $(\mathrm{g})$

Firmeza da polpa da polpa $(\mathrm{N})$

Cor de fundo $L^{*}$

Cor de fundo $\mathrm{C}^{*}$

Cor de fundo $\mathrm{h}$

Sólidos solúveis ( ${ }^{\circ}$ Brix)

76,72 a 77,58

45,28 a 46,88

Acidez titulável ( $g$ de ácido

málico/100g)

66,13 a 67,20

41,48 a 42,44

94,11 a 95,88

7,44 a 9,25

"Ratio"

0,07 a 0,464

29,297 a 33,392

Os resultados dos ensaios de avaliação do impacto sobre a qualidade do fruto mostraram que:

A acidez variou significativamente com a altura de impacto e a época de avaliação (Tabelas 20,21 e 22), mas só mostrou diferença significativa entre os impactos de 5 e $15 \mathrm{~cm}$ de altura, semelhantes ao controle. $O$ teor de sólidos solúveis do pêssego não sofreu mudança significativa com a altura ou com a época de avaliação (Tabelas 20 e 21).

O "ratio" apresentou variação significativa com a época de avaliação, em função da variação significativa da acidez (Tabelas 20 e 21).

A firmeza da polpa variou significativamente com a época de avaliação (Tabelas 20 e 23), um comportamento característico do processo de amadurecimento, em que a polpa fica mais macia a medida que as substâncias pécticas que compõem as paredes celulares tornam-se solúveis (Kluge, et al. 2002) e não variou com a altura do impacto. Os estudos de Crisosto (1994), Crisosto et al., (1996) e 2000 e Crisosto \& Kader (2001), mostram uma grande variação da firmeza da polpa, em frutos do mesmo cultivar, em 
diferentes locais de um mesmo fruto, em frutos localizados em diferentes posições na mesma árvore, em diferentes épocas do ano, fazendo com que seja muito difícil a sua utilização como medida de ponto de colheita. Levantamento preliminar das características de diferentes cultivares de pêssego encontrados no Entreposto Terminal de São Paulo em 2003, mostra firmeza média da polpa de 2,4 N, variando de 0,0 a 20,0 N, em 391 pêssegos analisados. A firmeza média da polpa foi $7,9 \mathrm{~N}$, variando de 1,5 a $16,0 \mathrm{~N}$, nos 19 pêssegos 'Aurora' analisados. A firmeza da polpa, no presente ensaio, variou de 41,57 a $34,32 \mathrm{~N}$ na primeira época de avaliação e de 28,28 a $24,10 \mathrm{~N}$ na segunda época de avaliação, valores superiores às firmezas de polpa encontradas no levantamento preliminar aqui relatado. A maior firmeza dos frutos deste ensaio se deve à época do ano (a colheita foi feita no início da safra, em condições de clima muito seco), às condições ambientais de armazenamento (o fruto foi armazenado em condições constantes de temperatura e umidade: $23^{\circ}$ C e 85 a 90\%UR). A utilização da classificação de Schulte et al. (1994) em 5 grupos de firmeza de polpa para o pêssego enquadrou todos os pêssegos da $1^{\text {a }}$ avaliação (época 2 ) como firme, e os pêssegos da $2^{a}$ avaliação (época 4) como macio, em todas as alturas de impacto. A sensibilidade a impactos, de diferentes alturas, varia muito com o cultivar e a firmeza da polpa do fruto (Crisosto et al., 1996, 2000 e 2001). Schulte et al.(1994) obtiveram 100\% de probabilidade de ocorrência de dano num fruto macio, para quedas maiores que $100 \mathrm{~mm}$, direcionadas para atingir a sutura do fruto. A mesma probabilidade, para um fruto classificado como firme, exigiu uma queda superior a $200 \mathrm{~mm}$. A diferença de resistência entre os diversos cultivares é muito grande (Berardinelli et al., 2001). O 
pêssego 'Aurora' é, de acordo com os produtores, um pêssego mais resistente ao manuseio.

Tabela 20. Significância da estatística $F$, para os efeitos considerados no modelo de análise de variância e coeficiente de variação, no ensaio de avaliação do impacto sobre a qualidade do fruto: teor de sólidos solúveis, acidez,"ratio" e firmeza da polpa

\begin{tabular}{lccccc}
$\begin{array}{l}\text { Fonte de } \\
\text { variação }\end{array}$ & $\begin{array}{c}\text { Perda de } \\
\text { massa }\end{array}$ & $\begin{array}{c}\text { Teor de } \\
\text { sólidos } \\
\text { solúveis }\end{array}$ & $\begin{array}{c}\text { Acidez } \\
\text { titulável }\end{array}$ & "Ratio" & $\begin{array}{c}\text { Firmeza da } \\
\text { polpa }\end{array}$ \\
\hline Altura & $(\mathrm{g})$ & ${ }^{\circ}$ Brix & $\begin{array}{c}\text { (g de ácido } \\
\text { málico/100g) }\end{array}$ & & (N) \\
$\begin{array}{l}\text { Época de } \\
\text { avaliação }\end{array}$ & $* *$ & $\mathrm{Ns}$ & $* *$ & $* *$ & $* *$ \\
$\begin{array}{l}\text { Altura } \mathrm{x} \\
\text { Época }\end{array}$ & $*$ & $\mathrm{Ns}$ & $\mathrm{ns}$ & $\mathrm{ns}$ & $\mathrm{Ns}$ \\
$\mathrm{CV}(\%)$ & 8,49 & 6,34 & 9,06 & 10,09 & 15,53 \\
\hline
\end{tabular}

ns o efeito ou fator considerado é não significativo $(a>0,05)$

o efeito ou fator considerado tem significância $(a<0,05)$

** o efeito considerado tem alta significância $(a<0,01)$ 
Tabela 21. Efeito da altura do impacto no teor de sólidos solúveis, na acidez e no "ratio" do fruto após 2 dias e 4 dias na polpa de pêssegos 'Aurora'

Teor de sólidos solúveis
Acidez titulável

( $g$ de ácido málico/100g)

"Ratio"

Altura

$(\mathrm{cm})$

( ${ }^{\circ}$ Brix) dias após o tratamento

2 dias 4 dias 2 dias 4 dias 2 dias 4 dias

$\begin{array}{lllllll}0 & 8,75 a & 8,46 a & 0,29 a b & 0,25 a b & 30,32 b & 33,85 a\end{array}$

$5 \quad 8,50$ a $\quad 9,00 a \quad 0,31 a \quad 0,27 a \quad 27,31 b \quad 34,16 a$

$10 \quad 8,56 a \quad 9,60 a \quad 0,28 a b \quad 0,24 a b \quad 30,22 b \quad 39,94 a$

$\begin{array}{lllllll}15 & 9,23 a & 9,06 a & 0,28 b & 0,23 b & 33,33 b & 39,82 a\end{array}$

$\begin{array}{lllllll}\text { Média } & 8,76 a & 9,03 a & 0,29 a b & 0,25 a b & 30,30 \mathrm{~b} & 36,94 \mathrm{a}\end{array}$

As diferenças foram significativas para letras diferentes $(a<0,05)$ pelo teste F.

Tabela 22. Efeito da altura de impacto na acidez titulável média de pêssegos 'Aurora'

\begin{tabular}{cc}
\hline $\begin{array}{c}\text { Altura } \\
(\mathrm{cm})\end{array}$ & $\begin{array}{c}\text { Acidez titulável } \\
(\mathrm{g} \text { de ácido málico/100g) }\end{array}$ \\
\hline 0 & $0,27 \mathrm{ab}$ \\
5 & $0,29 \mathrm{a}$ \\
10 & $0,26 \mathrm{ab}$ \\
15 & $0,25 \mathrm{~b}$ \\
\hline
\end{tabular}

As diferenças foram significativas para letras diferentes $(a<0,05)$ pelo teste $\mathrm{F}$. 
Tabela 23. Efeito da altura do impacto na firmeza da polpa de pêssegos 'Aurora'

Firmeza da polpa

Altura

$(\mathrm{cm})$

$(\mathrm{N})$

Avaliação

(dias após o tratamento)

\begin{tabular}{ccc} 
& 2 dias & 4 dias \\
\hline 0 & $40.26 \mathrm{a}$ & $24.48 \mathrm{~b}$ \\
5 & $41.57 \mathrm{a}$ & $28.28 \mathrm{~b}$ \\
10 & $38.73 \mathrm{a}$ & $24.59 \mathrm{~b}$ \\
15 & $34.32 \mathrm{a}$ & $24.10 \mathrm{~b}$ \\
Média & $38.72 \mathrm{a}$ & $25.36 \mathrm{~b}$ \\
\hline
\end{tabular}

As diferenças foram significativas para letras diferentes $(a<0,05)$ pelo teste $\mathrm{F}$.

Houve mudança significativa, das variáveis $C^{*}, L^{*}$ e $h$, atributos da cor de fundo, com a época de avaliação. Houve aumento significativo na variável $C^{*}$ e uma diminuição na variável $\mathrm{h}$ com a época (Tabelas 24, 25 e 26). A cor de fundo L*, medida de luminosidade, aumentou significativamente, pelo teste de Tókio, entre 5 e $15 \mathrm{~cm}$ de altura (Tabela 25). As alturas de 5 e $15 \mathrm{~cm}$, mostraram também, para algumas das outras características medidas - acidez, "radio" e a perda percentual de massa fresca - a menor e a maior sensibilidade ao impacto. A cor de fundo é a característica não destrutiva mais adequada à identificação do ponto de maturação mínimo, segundo Crisosto (1994) e Delwiche \& Baumgardner (1985). A mudança significativa, com a época de avaliação, das 3 variáveis $C^{*}, L^{*}$ e $h$ da cor de fundo é característica do processo de amadurecimento - aumento na variável $C^{*}$ e uma diminuição na variável $h$ com a época. A epiderme dos frutos ficou mais amarela e perdeu brilho com o amadurecimento. Não foi observada nenhuma mudança visível a olho nu no aspecto da 
epiderme no local de impacto ou na cor da polpa, imediatamente abaixo do local de impacto.

Tabela 24. Significância da estatística F, para os efeitos considerados no modelo de análise de variância e coeficiente de variação, no ensaio de avaliação do impacto sobre a qualidade do fruto: cor de fundo

\begin{tabular}{lccc}
\hline & \multicolumn{3}{c}{ Cor de fundo } \\
\cline { 2 - 4 } Fonte de variação & $\mathrm{L}^{*}$ & $\mathrm{C} *$ & $\mathrm{~h}$ \\
\hline Altura & $*$ & $\mathrm{~ns}$ & $\mathrm{~ns}$ \\
Época de avaliação & $* *$ & $* *$ & $* *$ \\
Altura x Época & $\mathrm{Ns}$ & $\mathrm{ns}$ & $\mathrm{ns}$ \\
$\mathrm{CV}(\%)$ & 2,07 & 3,87 & 3,86 \\
\hline
\end{tabular}

ns o efeito ou fator considerado é não significativo $(a>0,05)$

* o efeito ou fator considerado tem significância $(a<0,05)$

** o efeito considerado tem alta significância $(a<0,01)$

Tabela 25. Influência da altura de impacto na cor de fundo do pêssego 'Aurora'

\begin{tabular}{ccccc}
\hline Altura $(\mathrm{cm})$ & L* $^{*}$ & $\mathrm{C}^{*}$ & $\mathrm{~h}$ & \\
\hline 0 & & & & \\
5 & $66,6240 \mathrm{ab}$ & $46,4970 \mathrm{a}$ & 86,130 & $\mathrm{a}$ \\
10 & $65,2463 \mathrm{~b}$ & $45,0098 \mathrm{a}$ & 84,083 & $\mathrm{a}$ \\
15 & $66,2315 \mathrm{ab}$ & $46,2027 \mathrm{a}$ & 84,655 & $\mathrm{a}$ \\
\hline
\end{tabular}

As diferenças foram significativas para letras diferentes $\quad(a<0,05)$ pelo teste $F$. 
Tabela 26. Influência da época de avaliação na cor de fundo do pêssego 'Aurora'

\begin{tabular}{lcc}
\hline Época & $L^{*}$ & $C^{*}$ \\
\hline 2 dias & $65,0685 \mathrm{a}$ & $43,6096 \mathrm{~b}$ \\
4 dias & $67,6429 \mathrm{a}$ & $48,7202 \mathrm{a}$ \\
\hline As diferenças foram significativas para letras diferentes $(a<0,05)$ pelo teste \\
F.
\end{tabular}

A perda de massa fresca variou significativamente com a época de avaliação e apresentou interação entre a altura e a época de avaliação (Tabelas 20 e 26). Houve diferença significativa de perda percentual de massa fresca entre os tratamentos (altura) 5 e $15 \mathrm{~cm}$ (Tabela 26), pelo teste $F(a<0,05)$. Em condições semelhantes de temperatura e umidade relativa do ar, o coeficiente de transpiração depende da permeabilidade da fruta à perda de água (Labavitch et al., 1988). A perda percentual de massa fresca é uma medida direta da perda de água, da diferença de permeabilidade entre os frutos, submetidos a impactos diferentes. A perda percentual de água aumentou com a altura do impacto. Entretanto o comportamento da perda percentual variou com a época de avaliação. A figura 10 mostra o aumento de perda percentual de massa fresca de 0 até $10 \mathrm{~cm}$ de altura de impacto na avaliação de 2 dias, e sua diminuição quando a altura de impacto sobe para $15 \mathrm{~cm}$. Na avaliação de 4 dias a perda percentual de massa fresca cresce até a altura de impacto até $5 \mathrm{~cm}$, quando começa a cair. 


\section{口2 dias $\mathbf{0} 4$ dias}

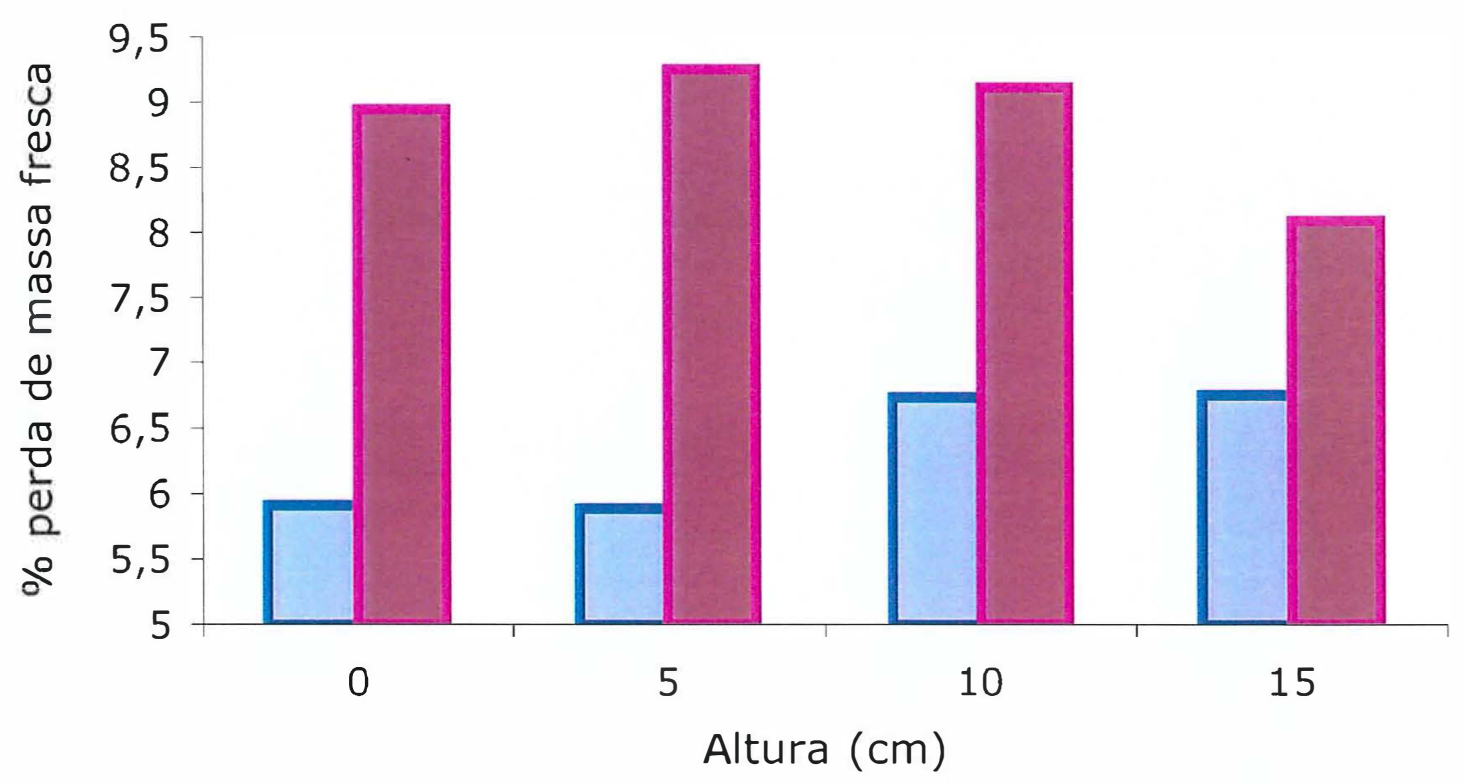

Figura 10 - Efeito da altura do impacto, na perda percentual de massa fresca do pêssego 'Aurora', após 2 dias e 4 dias

O ensaio do efeito do impacto no metabolismo avaliou a massa fresca do fruto, a produção de etileno e a intensidade de respiração, dos frutos submetidos aos mesmos tratamentos de impacto do $1^{\circ}$ ensaio, em 6 leituras (dias). Os resultados mostraram que:

Não há diferenças significativas, pela análise de variância entre os tratamentos (altura de impacto), na produção de etileno, na intensidade da respiração (medida pela emissão de $\mathrm{CO}_{2}$ ) e na massa fresca, em cada uma das seis leituras. Só existe diferença significativa entre as leituras (Tabela 27) e quando consideramos os dados acumulados até cada leitura. Cada leitura acumulada é o resultado da sua leitura mais os resultados das leituras anteriores. 
Tabela 27. Análise de variância para o ensaio de avaliação do efeito do impacto sobre o metabolismo do fruto

\begin{tabular}{lcc} 
Fonte de variação & $\mathrm{CO}_{2}$ & Massa fresca \\
\hline Altura & $\mathrm{Ns}$ & $\mathrm{Ns}$ \\
Leitura & $* *$ & $* *$ \\
Altura x Leitura & $\mathrm{ns}$ & $\mathrm{Ns}$ \\
$\mathrm{CV}(\%)$ & 9,57 & 0,62 \\
\hline
\end{tabular}

ns o efeito ou fator considerado é não significativo $(a>0,05)$

* o efeito ou fator considerado tem significância $(a<0,05)$

** o efeito considerado tem alta significância $(a<0,01)$

A variabilidade da produção de etileno foi altíssima e a sua análise de variação foi desconsiderada. A análise de regressão para a produção de etileno foi não significativa para as alturas 0 e 15 $\mathrm{cm}$. Os valores da regressão quadrática mostraram para a altura 5 $(p=0.0093, R=0.34)$ e para a altura $10(p=0.022, R=0.17)$, uma relação positiva. O tratamento com altura de impacto de $15 \mathrm{~cm}$ mostrou uma produção inicial de etileno superior a dos outros tratamentos e um pico de produção de etileno na $3^{a}$ leitura, na altura de impacto de $10 \mathrm{~cm}$ (Figura 11). Todos os tratamentos de impacto apresentaram uma produção inicial de etileno superior à ausência de impacto. 


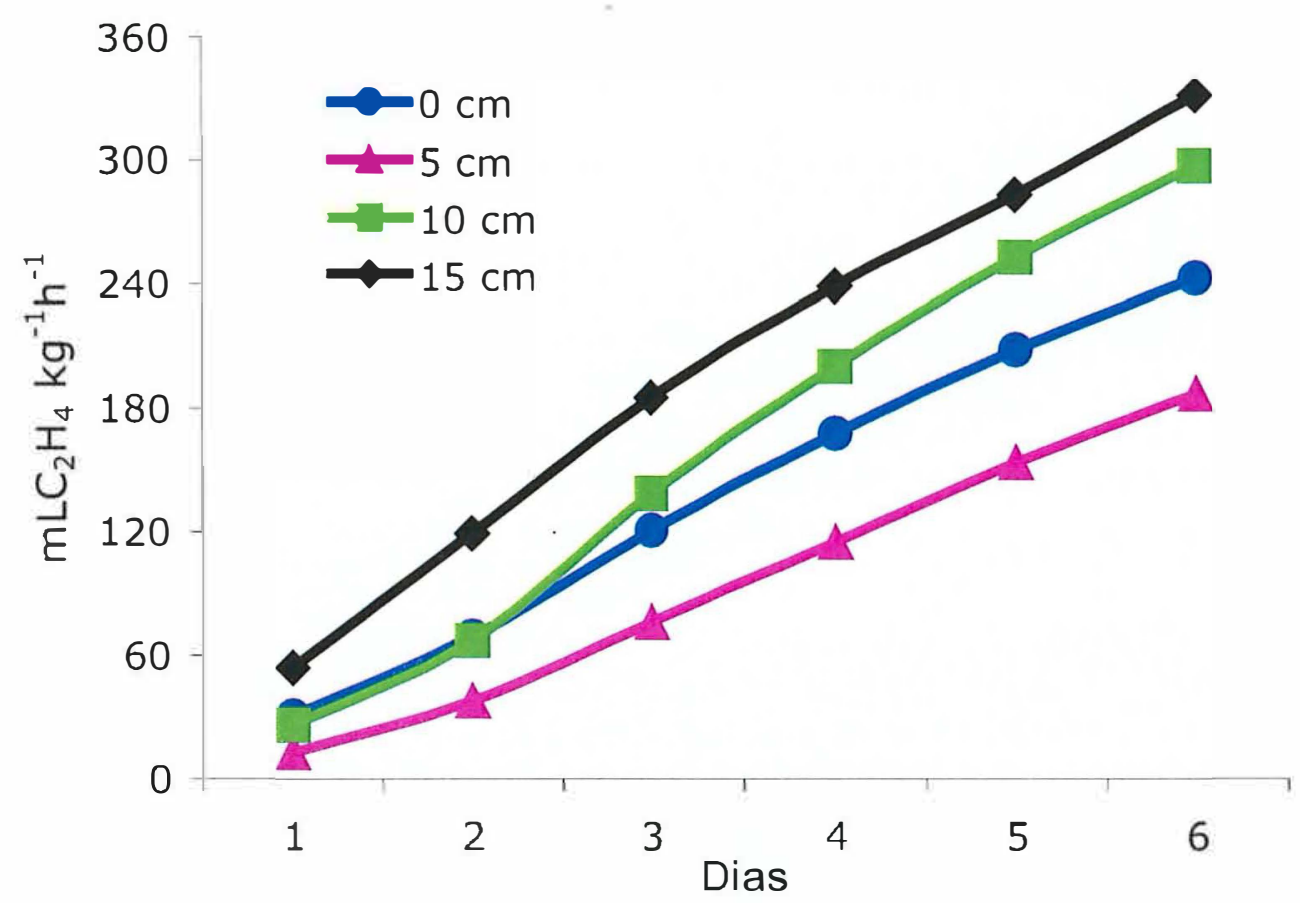

Figura 11 - Produção de etileno em pêssego 'Aurora' em função da altura de impacto

A intensidade ou taxa respiratória é um dos fatores determinantes do potencial de longevidade das frutas durante a póscolheita. Entre os fatores que afetam a respiração estão a temperatura, a composição atmosférica e o estresse (Kluge, et al., 2002). A intensidade da respiração foi mais sensível ao impacto e conseguiu registrar o seu efeito mesmo sem a alteração na aparência do fruto. Mattiuz (2002) mediu o efeito de injúrias mecânicas e no processo respiratório e nas variáveis químicas de goiabas 'Paluma' e 'Pedro Sato'. Todos os frutos, submetidos às injúrias mecânicas - 
corte, compressão e impacto - produziram maior quantidade de $\mathrm{CO}_{2}$ que os frutos do controle. $\mathrm{Na}$ injúria por impacto os incrementos de produção foram maiores. Burton \& Schulte-Pason (1987) atribuem o aumento da respiração com o impacto à descarboxilação do ácido málico, que extravasa das células danificadas no local de ocorrências dos danos, e recomendam a intensidade da respiração como uma das medidas de avaliação do efeito do impacto. $\mathrm{Na}$ análise de regressão, a taxa de respiração, medida através do $\mathrm{CO}_{2}$ liberado, apresentou uma relação linear positiva significativa $(P<0,05)$ em todos os níveis de alturas de queda do fruto testados. $A$ análise de regressão linear para a intensidade da respiração mostrou que o efeito do tempo sobre a intensidade da respiração é altamente significativo. A intensidade da respiração, a partir da $5^{a}$ leitura, mostrou um incremento maior no tratamento de $15 \mathrm{~cm}$ de altura de impacto e uma diferenciação nas tendências de crescimento, dos tratamentos de $0 \mathrm{~cm}$ e $10 \mathrm{~cm}$ com os tratamentos de 5 e $15 \mathrm{~cm}$ (Figuras 12 e 13).

As figuras 12 e 13 que representam a intensidade da respiração e a perda percentual de massa fresca, mostram um comportamento semelhante das duas características avaliadas. A análise de regressão linear para a massa fresca mostrou que o efeito do tempo é altamente significativo. O efeito do impacto de $5 \mathrm{~cm}$, em relação ao impacto zero, só foi registrado pela perda percentual de massa fresca. Nas outras características observadas, a produção de etileno e a intensidade de respiração, o impacto de $5 \mathrm{~cm}$ apresentou medidas menores que a testemunha (ausência de impacto). Em condições semelhantes de temperatura e umidade relativa do ar, o coeficiente de transpiração depende da permeabilidade da fruta à perda de água (Labavitch et al. 1988). A perda percentual de massa 
fresca é uma medida direta da perda de água, da diferença de permeabilidade entre os frutos, submetidos a impactos diferentes. A variação da massa fresca é uma medida de aplicação simples e barata e pouco utilizada na avaliação da qualidade do fruto. Ela registrou o efeito do impacto e apresentou um comportamento semelhante à intensidade de respiração, de análise complexa e cara. Foi a única medida que registrou o efeito do impacto de $5 \mathrm{~cm}$ de altura em relação ao tratamento sem impacto. 


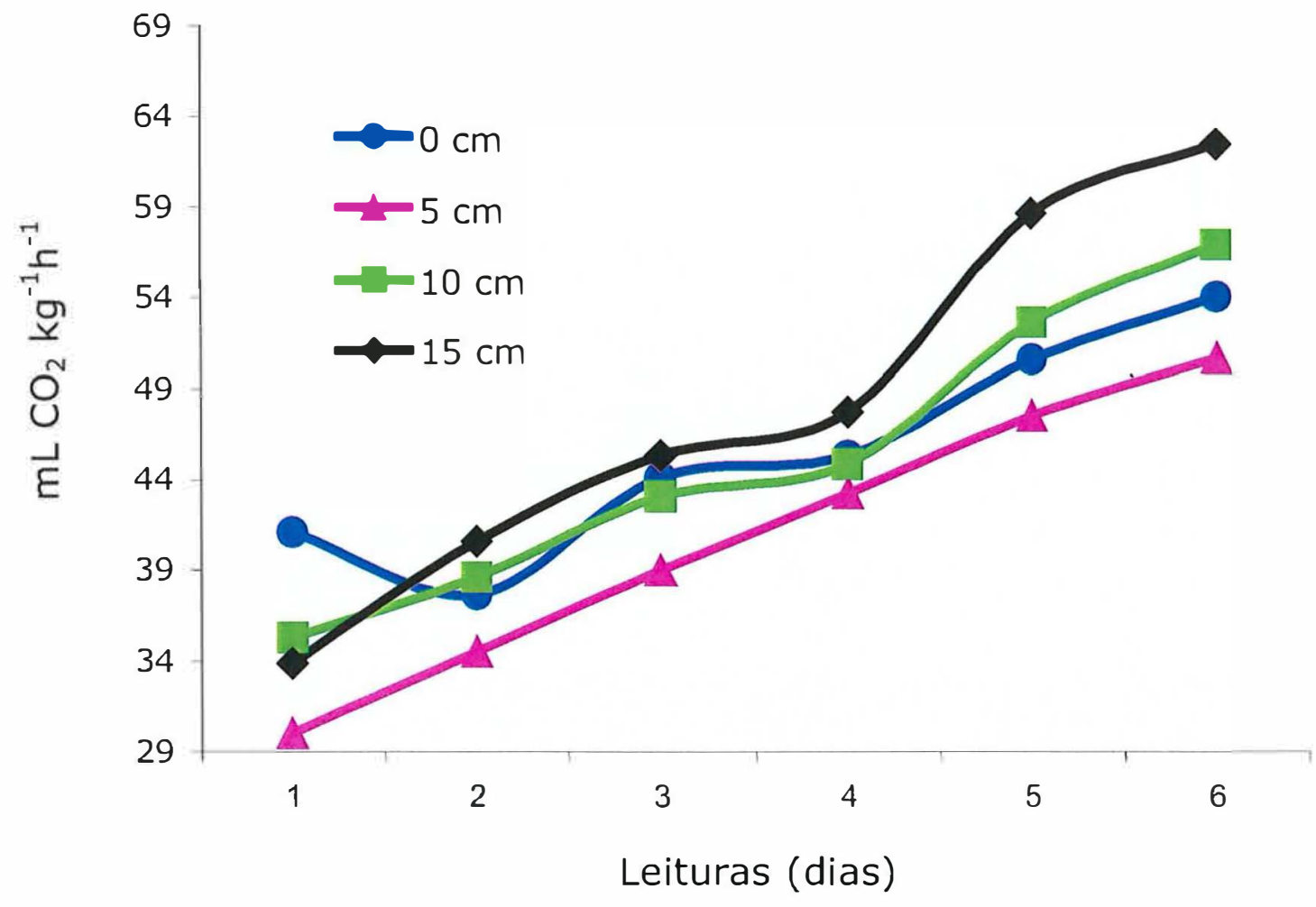

Figura 12 - Taxa de respiração, medida através da produção de $\mathrm{CO}_{2}$, em pêssego Aurora em função da altura de impacto, em cada leitura 


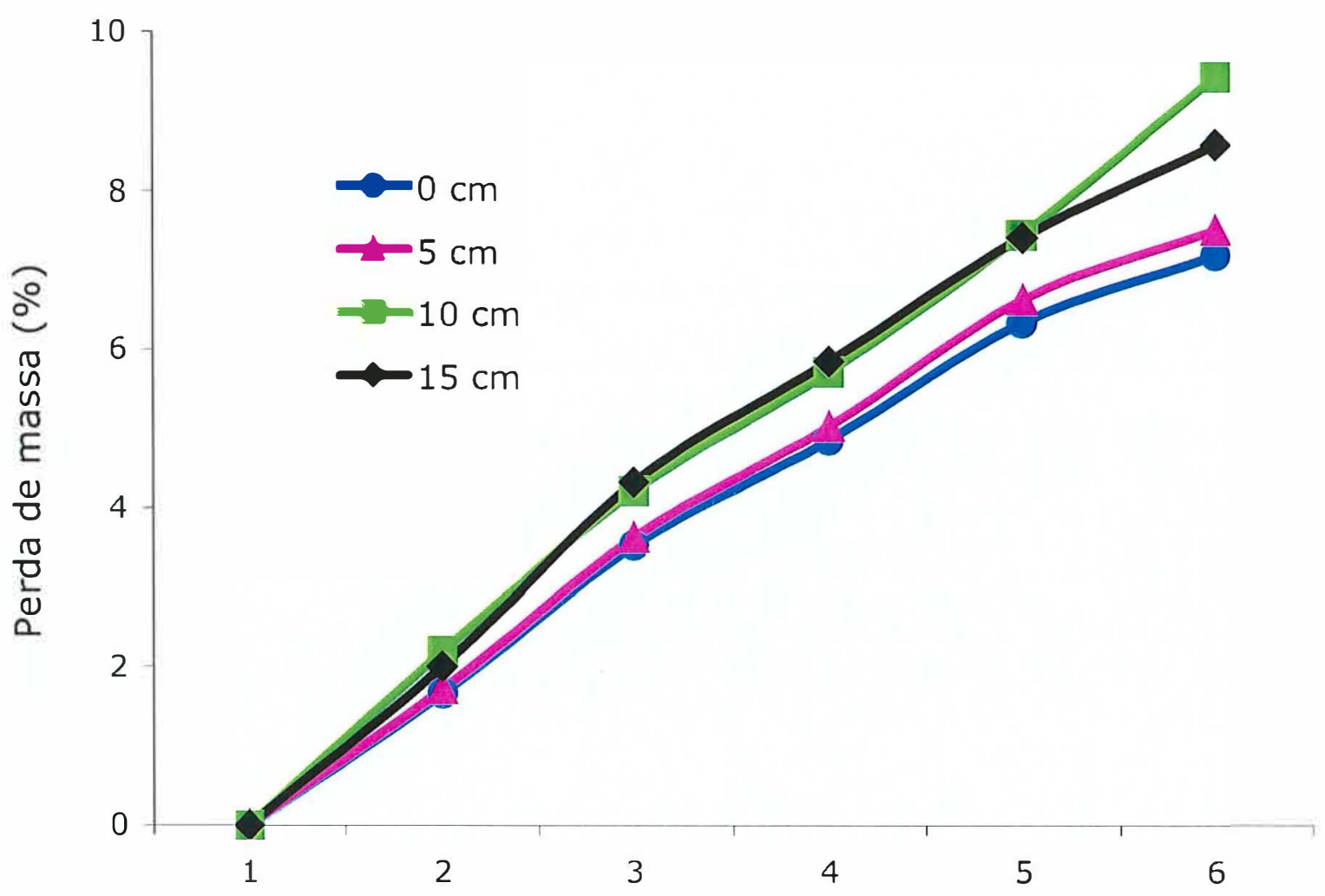

Dias

Figura 13 - Perda percentual de massa fresca no ensaio de avaliação de metabolismo, em diferentes alturas de impacto 


\subsection{Conclusões}

Não houve efeito visível do impacto nos pêssegos 'Aurora' submetidos a quedas sobre uma chapa de aço, das alturas de 5,10 e $15 \mathrm{~cm}$.

A firmeza da polpa e a cor de fundo evoluíram com a época, mudanças características do processo de amadurecimento.

$O$ efeito do impacto foi registrado pela perda percentual de massa fresca, a acidez, o "ratio", a cor de fundo $L *$, a intensidade de respiração e pela produção inicial de etileno. A maior diferença foi observada entre as alturas 5 e $15 \mathrm{~cm}$ de impacto. 


\section{A PERDA DA MASSA FRESCA DO PÊSSEgo NA PÓS-COLHEITA, EM DIFERENTES ELOS DA CADEIA DE PRODUÇÃO}

\section{Resumo}

A permeabilidade à perda de água para a atmosfera varia com a espécie, o cultivar e com as práticas de produção e manejo na colheita e pós-colheita da fruta. A variação da perda de massa fresca pode retratar os efeitos do manuseio em cada ponto da cadeia. Um ensaio com pêssego 'Aurora', em diferentes pontos da cadeia de produção, no auge da sua safra, foi realizado para determinar se a medida da perda de massa fresca do fruto pode servir como medida da intensidade do manuseio na colheita e pós-colheita do pêssego. Este experimento se restringiu às atividades de colheita e classificação: coleta do fruto na planta, na sacola da colhedora, imediatamente antes da entrada da máquina de classificação e na saída da máquina de classificação (fruto já embalado). A medida da massa fresca foi feita no dia da colheita e no $1^{\circ}$ e $4^{\circ}$ dias depois da colheita. A perda de massa fresca cresceu com o tempo e com o manuseio do fruto. A perda percentual da massa fresca foi menor no pêssego coletado na planta e na sacola da colhedora e foi crescendo nos outros pontos de coleta até que mais do que dobrou na saída do barracão de classificação. Só não houve diferença significativa de perda de massa fresca entre a planta e a sacola da colhedora. Houve 
correlação na perda de massa fresca entre as duas épocas de avaliação $(r=0,98)$. A maior perda de massa fresca aconteceu entre a entrada e a saída da máquina de classificação no $1^{\circ}$ dia depois da colheita. O ponto de coleta na planta, onde o fruto foi submetido ao menor manuseio possível, apresentou uma perda percentual de massa fresca que foi de $2,74 \%$, no $1^{\circ}$ dia depois da colheita, para $8,13 \%$ no $4^{\circ}$ dia depois da colheita. Essa perda só pode ser diminuída pela melhoria das condições do ambiente de comercialização. A perda de massa fresca pode se tornar um bom instrumento de medida do efeito do manejo de pós-colheita do pêssego para a determinação dos pontos críticos da pós-colheita por técnicos de campo e produtores. A medida da perda de massa fresca, operação muito simples e rápida, não exige conhecimentos especiais e o equipamento para a sua execução é barato e fácil de encontrar. É preciso compreender melhor o mecanismo fisiológico da perda de massa fresca do pêssego num universo de grande diversidade de cultivares, estádios de maturação de colheita, sistemas de colheita e pós-colheita e mensurar a sensibilidade da medida da perda de massa fresca a essa diversidade.

PALAVRAS-ChAVE: Prunus persica L., colheita, máquina de classificação.

\section{PEACH POSTHARVEST FRESH MATTER LOSS}

\section{Summary}

The permeability of the fruits to water loss depends of the species, cultivar and production, harvest and postharvest systems. To find if the fresh matter loss is a good measure of the 
effects of handling intensity in postharvest, peaches 'Aurora' were collected at different points of the production chain: the plant, the harvester bag, before the packinghouse mechanical selection and after the packinghouse mechanical selection. The fresh matter was measured one day and four days after harvest day and has increased with handling intensity and time. It has more than doubled from the first to the fourth day and from the plant to after the packinghouse mechanical selection. There were significant differences $(a<0,05)$ between the first and the fourth day after harvest day and between all the points of collection, except at the plant and the harvester bag. The major loss has occurred after the packinghouse mechanical selection, at the first day. The fresh matter loss behaviour was similar at the fist and fourth day $(r=0,98)$. Even at the point of minimum handling intensity, the plant, there was $2,74 \%$ fresh matter loss at the first day after harvest and $8,13 \%$ at the fourth day, an evidence of bad environmental conditions. Measuring the fresh matter loss of fresh peach, a very simple and cheap operation, doesn't demand special equipments or skills and can be a good instrument to evaluate harvest and post harvest handling intensity and to stablish the critical points of fresh peach postharvest systems. The inherent diversity of fresh peach - cultivars, maturity stages, production, harvest and postharvest systems demands further researches to better understand the sensibility of the fresh matter loss to handling intensity.

KEY WORDS: Prunus persica L., harvest, packinghouse.

\subsection{Introdução}


A transpiração é o principal processo envolvido na perda de matéria fresca (massa das frutas após a colheita). Ela é conseqüência do déficit de pressão do vapor (DPV) e do coeficiente de transpiração. O DPV é a diferença entre a pressão do vapor dos espaços intercelulares dos tecidos da fruta e a pressão do vapor do ar circundante a ela. O coeficiente de transpiração é a perda de umidade de uma fruta em uma unidade de tempo por déficit de pressão de vapor. Quanto maior o DPV entre a fruta e o ar circundante maior será a perda de água pela transpiração. O DPV é dependente da temperatura e da umidade relativa do ar (Kluge et al., 2002). Em condições semelhantes de temperatura e umidade relativa do ar podemos considerar que a transpiração depende da permeabilidade da fruta à perda de água (Labavitch et al.,1998).

A permeabilidade à perda de água para a atmosfera varia com a espécie, o cultivar e com as práticas de produção e manejo na colheita e pós-colheita da fruta. O efeito do manejo na permeabilidade da fruta é pouco estudado (Fresh Technologies, 2004) e a estratégia de prevenção das micro-rachaduras na cutícula da fruta é imprescindível, pois as rachaduras enfraquecem as propriedades da cutícula. A intensidade e a velocidade da perda de massa fresca são medidas que retratam os efeitos do manuseio em cada ponto da cadeia.

A medida da perda de massa fresca é uma operação simples, rápida e não exige conhecimentos especiais e o equipamento para a sua execução é barato e fácil de encontrar. O objetivo deste trabalho é determinar se a perda de massa fresca do fruto pode ser utilizada como medida da intensidade do manuseio na pós-colheita do pêssego. 


\subsection{Material e Métodos}

Foi realizado um ensaio para avaliar a perda da massa fresca do pêssego 'Aurora' nas diferentes etapas da pós-colheita da produção.

Os pêssegos foram coletados dia 30/10/2003. Os tratamentos consistiram da coleta nos seguintes pontos: na planta, na sacola da colhedora, na entrada da máquina de classificação e na saída da máquina de classificação. A massa fresca de cada fruto foi medida em 3 épocas: no dia da colheita; no $1^{\circ}$ dia depois da colheita; no $4^{\circ}$ dia depois da colheita. Os pêssegos estudados são da mesma origem na produção, dos pêssegos do primeiro ensaio e dos pêssegos aqui estudados em "Ocorrência de danos mecânicos na pós-colheita de pêssego 'Aurora' - da planta ao leilão de comercialização".

No momento da coleta, os frutos foram manuseados com todo cuidado e colocados em bandejas individualizadas em uma camada única numa caixa de papelão aberta. Os frutos foram armazenados a temperatura ambiente, nas condições normais de comercialização do Entreposto Terminal de São Paulo da CEAGESP Companhia de Entrepostos e Armazéns Gerais de São Paulo.

A massa fresca foi determinada, por pesagem de cada fruto individualmente, em balança Digipeso DP-3000, com precisão de um grama. Os frutos que apodreceram durante o período de pesagem foram descartados e não foram considerados na avaliação. As medidas utilizadas foram a perda percentual de massa fresca (determinada pela diferença entre a massa fresca do fruto no dia da coleta e no dia da avaliação, sendo os resultados expressos em \% da 
massa fresca inicial), e a intensidade da perda de massa fresca pontual (determinada pela subtração em cada ponto do valor registrado no ponto de coleta anterior e a sua divisão pelo número de dias pós-colheita).

Os ensaios foram conduzidos segundo o delineamento inteiramente ao acaso. Cada fruto foi uma repetição. Para cada tratamento coletou-se uma caixa de frutos com cem frutos por caixa.

\subsection{Resultados e Discussão}

Existem diferenças significativas $(a<0,05)$ de perda percentual de massa fresca entre as duas épocas de avaliação e entre todos os pontos de coleta, com exceção dos pontos de coleta na planta e na sacola da colhedora (Tabela 28). Houve um aumento progressivo de perda de massa fresca do fruto, com o aumento do manuseio do fruto: do fruto coletado na planta ao coletado na saída do barracão de classificação e um aumento de perda de massa fresca com o tempo, dentro do mesmo ponto de coleta (Tabela 29). A perda percentual da massa fresca foi menor no pêssego coletado na planta e foi crescendo nos outros pontos de coleta até que mais do que dobrou na saída do barracão de classificação (Tabela 29). Houve correlação na perda de massa fresca entre as duas épocas de avaliação $(r=0,98)$. Quando eliminamos o efeito de um ponto de coleta no outro através do cálculo da perda percentual de massa fresca pontual, é mais fácil observar o efeito isolado de cada ponto de coleta - a diferença entre as duas épocas no ponto de coleta sacola da colhedora e o salto na perda percentual de matéria fresca da entrada para a saída da máquina de classificação. A intensidade 
pontual da perda de massa fresca (Figura 14) é maior no $4^{\circ}$ dia que no $1^{\circ}$ dia depois da colheita, na planta e na sacola da colhedora, mas passa a ser menor nos pontos de entrada e de saída da máquina de classificação, o que indica uma diferença no comportamento inicial de perda de água. A maior intensidade de perda de massa fresca aconteceu entre a entrada e a saída da máquina de classificação no $1^{\circ}$ dia depois da colheita. O ponto de coleta na planta pode ser considerado como o sistema de coleta ideal, com o manuseio absolutamente necessário. Mesmo assim ele apresentou uma perda percentual de massa fresca que foi de $2,74 \%$, no $1^{\circ}$ dia depois da colheita, para $8,13 \%$ no $4^{\circ}$ dia depois da colheita, perda que só pode ser diminuída pela melhoria do ambiente de comercialização. Além dos danos por batida, compressão e até o corte do fruto, que podem acontecer na máquina de classificação, o manuseio do fruto na escolha na esteira e no embalamento e a sua movimentação na máquina de classificação possivelmente retiram do fruto uma parte da sua proteção natural contra a perda de água.

Tabela 28. Significância da estatística $F$ para os pontos de coleta do pêssego 'Aurora', da planta à saída do barracão de classificação

\begin{tabular}{lcccc}
\hline Coleta & $\begin{array}{c}\mathrm{Na} \\
\text { planta }\end{array}$ & $\begin{array}{c}\text { Na sacola } \\
\text { da } \\
\text { colhedora }\end{array}$ & $\begin{array}{c}\text { Na entrada } \\
\text { do barracão }\end{array}$ & $\begin{array}{c}\text { Na saída do } \\
\text { barracão }\end{array}$ \\
\hline Na planta & & $\mathrm{Ns}$ & $*$ & $*$ \\
Na sacola da colhedora & $\mathrm{Ns}$ & & $\mathrm{ns}$ & $*$ \\
$\begin{array}{l}\text { Na entrada do } \\
\text { barracão }\end{array}$ & $*$ & & $\mathrm{~ns}$ & $\mathrm{Ns}$ \\
Na saída do barracão & $*$ & $*$ & $\mathrm{~ns}$ & $\mathrm{Ns}$ \\
\hline
\end{tabular}
ns o efeito ou fator considerado é não significativo $(a>0,05)$ o efeito ou fator considerado tem significância $(a<0,05)$ 
Tabela 29. Perda acumulada de massa fresca total do pêssego 'Aurora', em função do ponto de coleta, em duas épocas $-1^{\circ}$ dia e $4^{\circ}$ dia

Pontos de coleta

Na planta

Na sacola da colhedora

$\mathrm{Na}$ entrada do barracão

Na saída do barracão

Média

\begin{tabular}{cc}
\multicolumn{2}{c}{ Perda acumulada $(\%)$} \\
\hline $1^{\circ}$ dia & $4^{\circ} \mathrm{dia}$ \\
\hline $2,74 \mathrm{c}$ & $8,13 \mathrm{c}$ \\
$2,98 \mathrm{c}$ & $9,27 \mathrm{c}$ \\
$3,78 \mathrm{~b}$ & $10,33 \mathrm{~b}$ \\
$7,45 \mathrm{a}$ & $14,28 \mathrm{a}$ \\
4,24 & 10,50
\end{tabular}

Letras diferentes representam diferenças significativas $(a<0,05)$ 


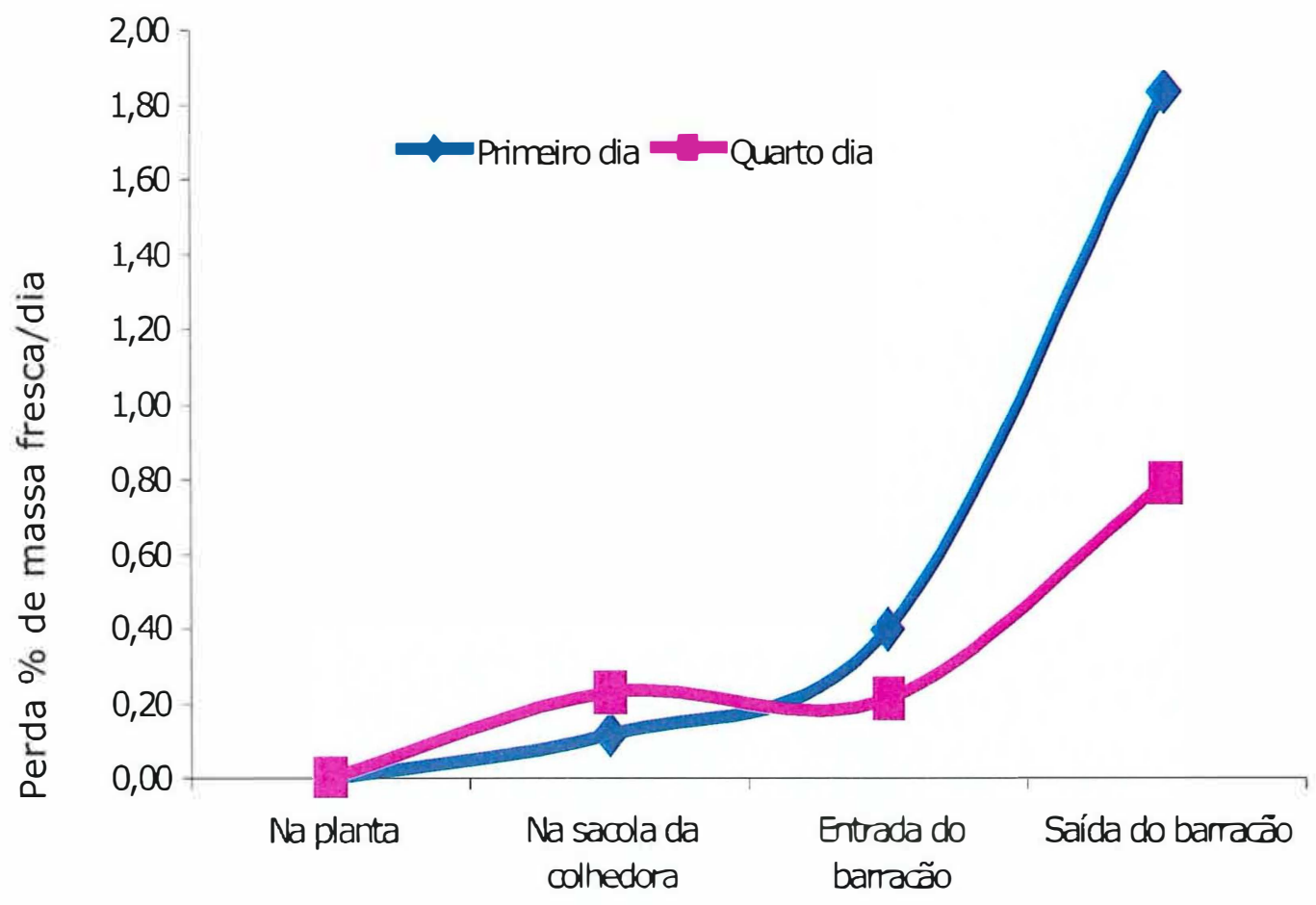

Pontos de coleta

Figura 14 - Intensidade da perda de massa fresca por dia e por ponto de coleta, no $1^{\circ}$ dia e $4^{\circ}$ dia depois da colheita, do pêssego 'Aurora', da planta à saída do barracão de classificação

É preciso compreender o mecanismo fisiológico da perda de massa fresca do pêssego submetido a diferentes manuseios, num universo de grande diversidade de cultivares, estádios de maturação de colheita, sistemas de colheita e pós-colheita e mensurar a sensibilidade da medida da perda de massa fresca a essa diversidade. 


\subsection{Conclusões}

Houve aumento de perda de massa fresca com o tempo e com o manuseio do fruto.

A perda percentual de massa fresca no ponto de coleta na planta, onde houve o menor manuseio possível, foi de 2,74\%, no $1^{\circ}$ dia depois da colheita, para $8,13 \%$ no $4^{\circ}$ dia depois da colheita, o que mostra a necessidade de melhoria do ambiente de comercialização.

A maior perda pontual de massa fresca foi registrada na saída do barracão de classificação.

A perda de massa fresca pode se tornar um bom instrumento de medida do efeito do manejo na colheita e pós-colheita do pêssego na pesquisa e na avaliação de pontos críticos no sistema de pós-colheita por técnicos de campo e produtores. 


\section{CONCLUSÕES GERAIS}

O dano mecânico é uma das principais causas de rejeição e desvalorização do pêssego fresco pelos varejistas no momento da sua compra no mercado atacadista de São Paulo - ETSP. O levantamento no mercado atacadista mostrou que a ocorrência de danos mecânicos é muito alta, chegando a $100 \%$ das caixas amostradas e que há correlação entre a freqüência de danos mecânicos e a freqüência de danos bióticos.

A ocorrência de anomalias é menor no início da safra, quando o volume da colheita é menor e o fruto é colhido com maior cuidado e maior firmeza de polpa. A simulação do impacto em laboratório, no início da safra, não mostrou efeitos visíveis. O efeito do impacto foi registrado pela maior perda percentual de massa fresca, a diminuição da acidez e do "ratio", a variação da cor de fundo $L^{*}$, a maior intensidade de respiração e a maior produção inicial de etileno.

Existe diferença significativa de incidência de dano mecânico entre origens (produtor), mostrando que o sistema de produção e o manejo pós-colheita do pêssego, adotados pelo produtor são determinantes na intensidade incidência.

A ocorrência de anomalias cresce consistentemente em cada elo da cadeia de produção. As anomalias desenvolvidas durante 
o processo de produção do fruto - lesão cicatrizada, dano por praga e dano fisiológico - não evoluem com o aumento do manuseio na cadeia. A ocorrência de dano por doença e dano mecânico póscolheita evoluem com o aumento do manuseio do fruto e apresentam uma relação linear positiva e significativa. Os pontos críticos de controle, onde deve ser priorizada a intervenção para a melhoria do sistema de pós-colheita na produção são a classificação mecânica e a colheita.

Houve aumento de perda de massa fresca com o aumento do manuseio do fruto. A perda de massa fresca pode se tornar um bom instrumento de medida dos dano sofridos pelo fruto durante o processo de colheita e pós-colheita. 
ANEXOS 


\section{Anexo A}

\section{Questionário Aplicado aos Atacadistas de Pêssego}

1)Dados da Empresa

Nome da Empresa:

Entrevistado:

Cargo:

Comprador de Frutas de

caroço:

Vendedor de frutas de

caroço:

Início das atividades (ano):

Pavilhão:

Box ou módulo:

Telefone:

e-mail:

2)Quais os cinco principais produtos que a sua empresa comercializa?

3)Quanto as frutas de caroço representam (\%) na comercialização da sua empresa, nos seguintes meses?

1 , setembro

2. outubro

3. novembro

4. dezembro
1 , setembro

5. janeiro

4)Que estado é o seu principal abastecedor nos seguintes meses?

1. setembro

2..outubro

3. novembro

4. dezembro

5. janeiro

5) Quais as principais regiões de cada Estado no abastecimento da sua empresa (município)?

6) De onde vem a melhor fruta? $\begin{array}{llllll}\text { Mês } & 09 & 10 & 11 & 12 & 01\end{array}$

Ameix

a

Nectari

na

Pêsseg

o

7) Se você fosse plantar frutas de caroço, que variedade de ameixa, pêssego e nectarina, que você escolheria?

Ameixa:

Nectarina: 
Ameixa:

Pêssego:

8) E qual seria a melhor região de plantio para tais frutas?

Ameixa:

Nectarina:

Pêssego:

9)Qual a tendência para os próximos cinco anos?

1. No. de fornecedores

2. Qualidade

3.Exigências quanto a qualidade

4. Exigências legais

5. Sazonalidade

6. Regiões de plantio

7. Volume de venda no ETSP

8. Preço de venda

9. Área de produção

10.Diminuição da área de produção

Ameixa:

Nectarina:

Pêssego:

10)Qual o sistema de comercialização utilizado pela sua empresa para as frutas de caroço?

1. Preço feito

2. Preço consignado

3. Mateiro

4. Outros. Qual?

Ameixa:

Nectarina:

Pêssego:
11) Quais são as 3 características mais importantes de um bom produtorfornecedor de frutas de caroço?

Ameixa:

Nectarina:

Pêssego:

12) Você tem dificuldades em garantir o abastecimento das frutas de caroço durante toda a safra? Em caso positivo, quais as principais dificuldades?

Ameixa:

Nectarina:

Pêssego:

13) Você tem comprador nas regiões produtoras de frutas de caroços? Em caso positivo, quais as atribuições deste comprador?

14) Quais são, na sua opinião, os principais problemas que atrapalham a comercialização das frutas de caroço?

Ameixa:

Nectarina:

Pêssego:

15) Quando você negocia por telefone e não conhece o produtor e nem a roça, quais perguntas que você faz para garantir o produto?

16)Quais são as principais reclamações dos compradores na hora da compra das frutas de caroço?

Ameixa:

Nectarina:

Pêssego: 
17) Você usa algum sistema de parceria com o produtor ou com associações de produtores?

1.Não utiliza sistema de parcerias

2.Financiamento da roça

3.Fornecimento de embalagem

4.Outro. Qual?

18)Quanto das frutas de caroço que você comercializa é de sua produção?

Ameixa:

Nectarina:

Pêssego:

19) Qual o percentual de frutas de caroço, que você comercializa, que passa pela CEAGESP?

Ameixa:

Nectarina:

Pêssego:

20) As frutas de caroço que não são comercializadas aqui na CEAGESP vão para onde? 21)Você prevê um aumento da produção e comercialização das frutas de caroço?

22) Quanto às vendas de frutas de caroço, qual a porcentagem:

1.Feita por telefone............\%

2.Feita no local ................\%

23)Quanto às frutas de caroço, qual a porcentagem:

1. Frutas retiradas no mercado pelo comprador.................\%

2.Frutas entregues pelo atacadista na loja do comprador $\%$
24)Para que as frutas de caroço comercializadas por sua empresa consigam uma melhor cotação ou ainda venda mais fácil, quais as exigências que seu produtor ou fornecedor deveria cumprir?

Todo dia aparece uma nova exigência legal: embalagem, classificação, rotulagem, ausência de resíduos, sanidade microbiológica.

Todos sabem que elas existem, ninguém cumpre e fica por isso mesmo.

25) Você acha que isso vai mudar?

\section{Sim}

2. Não

26) Você acha que estas exigências estão corretas?

1.Sim

2.Não

27)O que você sugere para que a mudança ocorra mais rapidamente?

28) V. teria mais algum comentário ou sugestão a respeito das exigências legais?

29)Qual é a classificação para tamanho e qualidade das frutas de caroço, que v. utiliza?

Ameixa:

Nectarina:

Pêssego:

30)Quais as variedades?

Ameixa:

Nectarina:

Pêssego:

Pesquisador:

Data: 


\section{Anexo B}

\section{Questionário Aplicado aos Compradores de Pêssego}

Nome do comprador:

Empresa:

Endereço

Telefone

E-mail:

Entrevistador

Data:

1) Você compra pêssego para?

Supermercado

Restaurante

Varejão

Feira

Cozinha industrial

Quitanda

Ambulante

Rede de distribuição

Sacolão

Outro CEASA

Outro

Qual?

2) O pêssego comprado no

ETSP destina-se a(o):

Município de São Paulo

Região metropolitana

Interior de SP

Litoral

Outro estado. Qual?

3) Você compra pêssego

somente na CEAGESP?

Sim Não Onde?

4) De quantos atacadistas você compra pêssego?

Um

Dois

Três

Mais de três. Quantos?
5) Quais são os principais atacadistas de quem você compra pêssego?

6) Qual é a forma predominante de comunicação com o seu fornecedor?

Pessoalmente

Por telefone

Por fax

Por e-mail

Outra. Qual?

7) Qual é a forma de pagamento?

À vista À prazo. No de dias

8) Quantas vezes por semana você compra pêssego?

Uma

Duas

Três

Quatro

Cinco

Seis

9)Quais os dias da semana mais propícios para a venda do pêssego ao consumidor?

Segunda-feira

Terça-feira

Quarta-feira

Quinta-feira

Sexta-feira

Sábado

Domingo

10) Você estaria disposto a pagar mais por um fruto de melhor qualidade?

Sim Não. ......\% a mais

11) Quando você decide :

- o volume de compra

-as variedades que vai comprar

- o ponto de maturação 
- o tamanho do produto

a. no mercado na hora da compra

b. segue a lista de pedidos

c. depende só do preço

d.outros

12)Que características são mais importantes na rejeição do pêssego na hora da compra?

13)Qual é a sua perda \% de pêssego?

14)Quais são as principais causas dessas perdas?

15) Quais são os cuidados que devem ser tomados no varejo para conservar a qualidade do pêssego?

16) Como você caracteriza o tamanho do pêssego e que tamanho você prefere?

17) Se você fosse fazer um pedido de pêssego por telefone, como você o descreveria para ter maior certeza de receber um produto de boa qualidade e fácil venda? Variedade

Tamanho

Cor

Maturação

Embalagem

Tipo

Peso liquido

Origem

Qualidade

18) Quais variedades compra?

\begin{tabular}{|l|l|}
\hline Aurora & Chiripá \\
\hline Dourado & Douradão \\
\hline Chimarrita & Flor da Prince \\
\hline Ouro Mel & Jóia \\
\hline
\end{tabular}

Outra(s)

19) Como você prefere o pêssego?
Polpa branca

Polpa amarela

Fundente

Não fundente

Caroço preso

Caroço solto

Formato

Cor da casca

Origem

20) Algumas variedades são mais plantadas em SP e outras variedades mais nos estados do Sul do Brasil. A época de entrada de cada origem é diferente.

\begin{tabular}{|l|l|l|}
\hline Origem & $\begin{array}{l}\text { Época } \\
\text { forte de } \\
\text { entrada }\end{array}$ & $\begin{array}{l}3 \\
\text { variedades } \\
\text { preferidas }\end{array}$ \\
\hline & & \\
\hline & & \\
\hline & & \\
\hline
\end{tabular}

21) Como é o seu volume médio semanal e distribuição de compra ao longo da safra?

\begin{tabular}{|l|l|}
\hline Mês & $\begin{array}{c}\text { Volume médio } \\
\text { semanal }\end{array}$ \\
\hline Setembro & \\
\hline Outubro & \\
\hline Novembro & \\
\hline Dezembro & \\
\hline Janeiro & \\
\hline \multicolumn{2}{|l|}{ 22) Você compra pêssego importado? }
\end{tabular}

Nunca

Sempre que disponível

Só quando não tem o pêssego

nacional

23) Você considera o pêssego importado melhor que o nacional?

Sim Não

Porque

24) Que tipo e que peso de embalagem prefere?

Papelão

Madeira

$\mathrm{kg}$

Madeira com bandeja

$\mathrm{kg}$

Madeira à granel 
$\mathrm{CP}$

Outro:

25) Quanto e o que está

comprando no dia de hoje? kg No de caixas:

Tipo de embalagem:

Variedade(s): 


\section{Anexo C}

\section{Levantamentos de Danos Pós-Colheita de Pêssego}

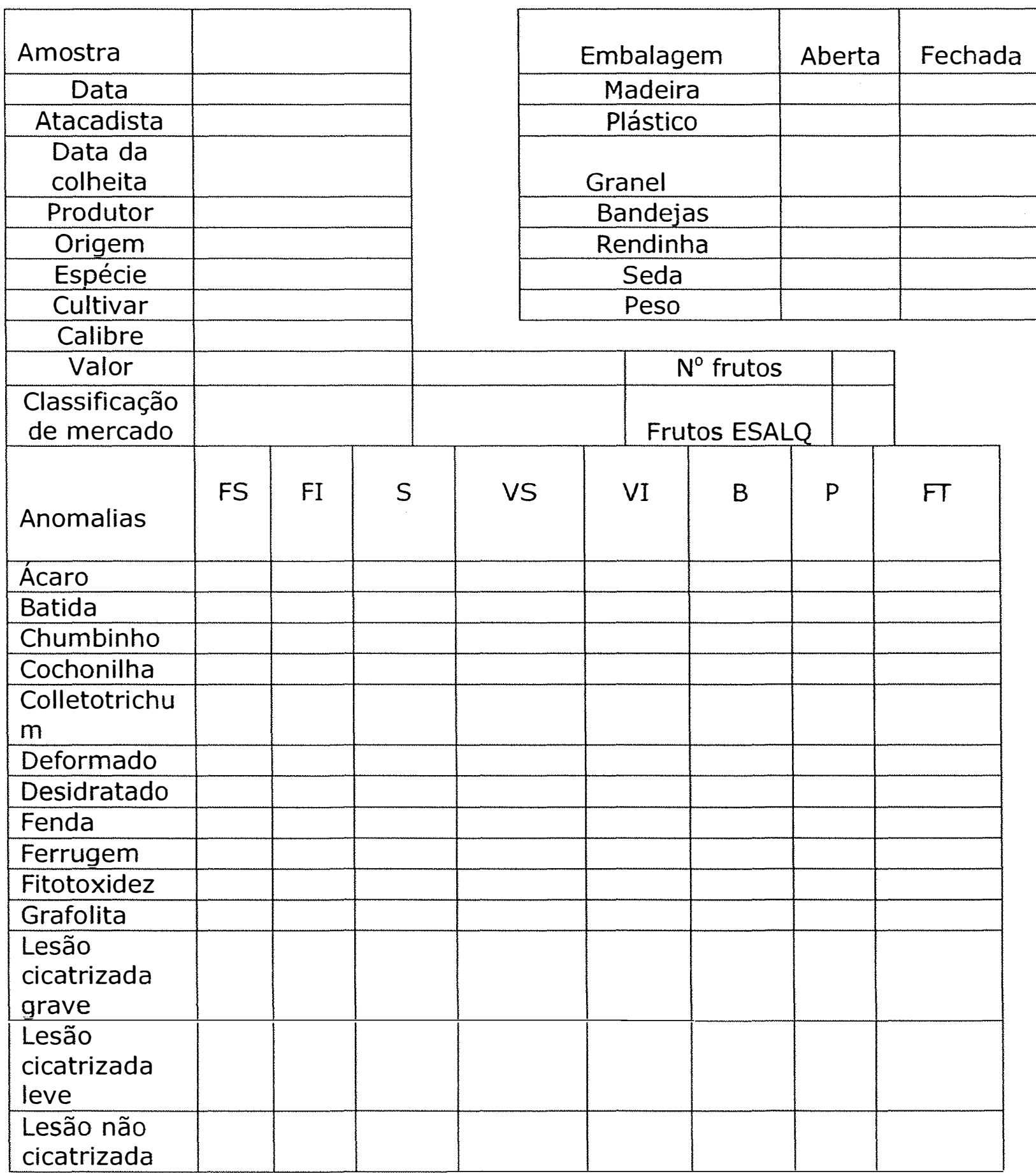




\begin{tabular}{|l|l|l|l|l|l|l|l|l|}
\hline Mancha & & & & & & & & \\
\hline Monilinia & & & & & & & & \\
\hline Percevejo & & & & & & & & \\
\hline Prensado & & & & & & & & \\
\hline $\begin{array}{l}\text { Queimadura } \\
\text { (sol) }\end{array}$ & & & & & & & & \\
\hline Rachadura & & & & & & & & \\
\hline Rhizopus & & & & & & & & \\
\hline Trips & & & & & & & & \\
\hline Unha & & & & & & & & \\
\hline Verruga & & & & & & & & \\
\hline $\begin{array}{l}\text { Frutos } \\
\text { verdes }\end{array}$ & & & & & & & & \\
\hline $\begin{array}{l}\text { Frutos } \\
\text { passados }\end{array}$ & & & & & & & & \\
\hline
\end{tabular}

FS - Frente superior

S - Sutura

VI - Verso inferior

$P$ - Pedúnculo
FI - Frente inferior

VS - Verso superior

B - Bico

FT - Fruto todo 


\section{REFERÊNCIAS BIBLIOGRÁFICAS}

ABBOT, J.A. Quality measurement of fruits and vegetables. Postharvest Biology and Technology, v. 15, p. 207-225, 1999.

ADASKayeg, J.E.; GUBler, W.D.; TeViOtdAle, B.L. Peach fruit rot.

UC IPM Pest Management Guidelines: Peach ripe fruit rot, University of California, UC ANR Publication 3454. on line, atualizado em 6 fev. 2004. http://www.ipm.ucdavis.edu/PMG/ r602100211.html (15 out. 2004).

ARAUJO, P.J. Manejo e conservação pós-colheita: fisiologia e tecnologia pós-colheita do pêssego. In: MEDEIROS, C.A.B.; RASEIRA, M.C.B. (Ed.). A cultura do pessegueiro. Brasília: Embrapa, SPI, 1998. p.318-339.

BERARDINELLI, A.; GUARNIERI, A.; PHUNTSO, J.; RAGNI, L. Fruit damage assessment in peach packing lines. Applied Engineering in Agriculture, v. 17, n.1, p. 57-62, 2001.

BOLIN H.R.; STAFFORD A.E.; KING J.R. A.D.; HUXSOLL C.C. Factors affecting the storage stability of shredded lettuce. Journal of Food Science, v. 42, n. 5, p. 1319-1321,1997. 
BRUSEWITZ G.H.; BARTZ, J.A. Impact parameters related to postharvest bruising of apples. Transactions of ASAE, v.26, n. 3, p. 953-957, 1989.

BURTON, C.L.; SCHULTE-PASON, N.L. Carbon dioxide as a indicator of fruit impact damage. Hortscience, v.22, n.2, p.281-282, 1987.

CAPPELLINI, R.A.; CEPONIS, M.J. Postharvest losses in fresh fruits and vegetables. In: MOLINE, H.E. (Ed.). Postharvest pathology of fruits and vegetables: postharvest losses in perishable crops. Davis: University of California, 1984, p. 24-30.

CEPONIS, M.J., CAPPELLINI, R.A., WELLS, J.M.; LIGHTNER, G.W. Disorders in plum, peach, and nectarine shipments in the New York market, 1972-1985. Plant Disease, v. 71, p. 947-952, 1987.

CHEN, P.; YAZDANI, R. Prediction of apple bruising due to impact on different surfaces. Transactions of ASAE, v. 34, n.3, p. 956-961, 1991.

COMISSÃO DAS COMUNIDADES EUROPÉIAS. Regulamento (CE) N. ${ }^{\circ}$ 2335/1999 da Comissão. Jornal Oficial das Comunidades Européias, p. 11-15, (nov. 1999).

CRISOSTO, C. H. Stone fruit maturity indices: a descriptive review. Postharvest News and Information, v. 5, n. 6, p. 65-68, 1994. 
CRISOSTO; C.H.; KADER, A. Peach: postharvest quality maintenance guidelines. http://www.uckac.edu/postharv/PDF/peach.pdf. jan. 2003).

CRISOSTO, C. H.; SLAUGHTER, D.; GARNER, D.; BOYD, J. Stone fruit critical bruising thresholds. Journal of the American Pomological Society, v. 55, n. 2, p. 76-81, 2001.

CRISOSTO, C.; AGUIRRE, M.; CRISOSTO, G.; SIMPSON, K.; GARNER, $D$. Developing critical thresholds for stone fruit. Central Valley Postharvest Newsletter, v. 5, n. 1, p. 11-13, 1996.

CRISOSTO, C. H.; METHENEY, P.D.; ROHNER, F.; GARNER, D.T.; DUNCAN, R.; DAY, K.; HASY, J.; BEEDE, B., GRADZIEL, T. Developing critical bruising thresholds for clingstone peaches. California cling peach board report 2000. Davis: California Cling Peach Board, 2000. 38 p.

DELWICHE, M.J.; BAUMGARDNER, R.A. Ground color as a peach maturity index. Journal of the American Society for Horticultural Science, v. 110, n. 1, p.53-57, 1985.

ECKERT, J.W.; OGAWA, J.M. The chemical control of post harvest diseases: deciduous fruits, berries, vegetables and root/tuber crops. Annual Review of Phytopatology, v.26, p. 433-469, 1988. 
FERREIRA, M.D. Levantamento para níveis de impacto utilizando a esfera instrumentada em máquinas de classificação de pêssego. In: REUNIÃO SOBRE A UTILIZAÇÃO DA ESFERA INSTRUMENTADA, Campinas: UNICAMP, 2003. p. 2 -11.

FERREIRA, M.D. Impacto registrado pela esfera instrumentada, submetida a diferentes alturas em duas superfícies de impacto: de aço e acolchoada. In: REUNIÃO SOBRE A UTILIZAÇÃO DA ESFERA INSTRUMENTADA, 2., Campinas: UNICAMP, 2004. 2- 4 p.

FRESH TECHNOLOGIES. Weight loss from pip fruit. Institute of Food Nutrition and Human Health. Massey University, on line, atualizado em 23 jul 2004. http://research.massey.ac.nz/ rsrchreports /2000/Sciences_2000.pdf. (15 out. 2004).

GARCIA, C.; RUIZ, M.; CHEN, P. Impact parameters related to bruising in selected fruits. St Joseph: ASAE 1988 (ASAE Paper, 88-6027).

GUTIERREZ, A.S.D. Regulamento técnico de identidade e qualidade de pêssego fresco: uma nova proposta. In: ENCONTRO NACIONAL DE CLASSIFICAÇÃO E PADRONIZAÇÃO DE PÊSSEGO E NECTARINAS, Bento Gonçalves: EMBRAPA, 2004. p 2-18.

HUNTERLAB. Insight on color. Hunterlab applications notes, v. 8, n. 11, 1996, on line. www.hunterlab.com (5 de set. 2004). 
INSTITUTO ANTONIO HOUAISS DE LEXICOGRAFIA. Dicionário Houaiss da Língua Portuguesa. Rio de Janeiro: Objetiva, 2001. 3992 p.

INSTITUTO BRASileiro DE GEOGRAFiA E eStATísticA. Censo Agropecuário de 1996. www.ibge.sidra.gov.br/ agricultura. (10 out. 2004).

INSTITUTO DE ECONOMIA AGRÍCOLA DO ESTADO DE SÃO PAULO. Banco de dados. http://www.iea.sp.gov.br/out/ ibcoiea.php. (10 out 2004).

KASAT, G.F. Efeito de injúrias mecânicas na qualidade pós-colheita de pêssegos Aurora-1. Jaboticabal, 2004. 47 p. Monografia (Graduação) - Faculdade de Ciências Agrárias e Veterinárias, Universidade Estadual Paulista "Júlio de Mesquita Filho".

KLUGE, R. A.; NACHTIGAL, J.C.; FACHINELLO, J.C.; BILHAVA, A.B. Fisiologia e manejo pós-colheita de frutas de clima temperado. Campinas: Livraria e Editora Rural, 2002. 214 p.

KUNZE, O.R; ALDRED, W.H.; REEDER, B.D. Bruising characteristics of peaches related to mechanical harvesting bruise susceptibility. Transactions of ASAE, v.18, n. 5, p.939-945, 1957.

LABAVITCH, J. M; GREVE, C.; MITCHAM, E. Fruit bruising: It's more than skin deep. Department of Pomology, UC: Perishables Handling Quarterly, v.95, n. 8, p. 7- 9, 1988. 
LIN, X.; BRUSEWITZ, G. H. Peach bruise thresholds using the instrumented sphere. Applied Engineering in Agriculture, v. 10, n. 4 , p. 509-513, 1994.

MANESS, N.O.; BRUSEWITZ, G.H.; MCCULLUM, T.G. Impact bruise resistance comparison among peach cultivars. Hortscience, v. 27, p.1008-1011, 1992.

MATTIUZ, B.H. Injúrias mecânicas e processamento mínimo de goiabas: fisiologia e qualidade pós-colheita. Jaboticabal, 2002. 120 p. Tese (Doutorado) - Faculdade de Ciências Agrárias e Veterinárias, Universidade Estadual Paulista "Júlio de Mesquita Filho".

MARTINS, M.C.; LOURENÇO, S.A.; GARCIA D. Quantificação de danos pós-colheita em pêssegos. In: CONGRESSO BRASILEIRO DE FITOPATOLOGIA, 36, Uberlândia, 2003. Fitopatologia Brasileira, v. 28 , p. 261-262, 2003.

MOHSENIN, N. N. Physical properties of plant and animal materials: structure, physical characteristics and mechanical properties. 2. ed. New York: Gordon and Breach, 1986. 891 p.

O' BRIEN, M.; CARGILL, B.F.; FRIDLEY, R.B. Principles and practices for harvesting and handling fruits and nuts, Florence, KY: AVI/VNR Publishing, 1983. 529 p. 
_OGUT, H.; AYDIN, C.; PEKER, A. Simulated transit studies on peaches: effect of container, cushion materials and vibration on elasticity modulus. Agricultural Mechanization in Asia, Africa and Latin America, v. 30, n. 3, p.59-62, 1999.

PELEG K.; HINGA, S. Stimulation of vibration damage in produce transportation. Transactions of ASAE, v. 29, n. 2, p. 633-641, 1986.

PROGRAMA PAULISTA PARA A MELHORIA DOS PADRÕES COMERCIAIS DE EMBALAGENS DE hORTIGRANJEIROS. Normas de classificação de pêssego e nectarina. São Paulo, CEAGESP, Centro de Qualidade em Horticultura, 1999. 4 p. (CQH. Documentos).

TECHMARK. The facts about bruise damage. http://www. techmark - inc.com/pdf/Brochure4.pdf. (4 jan. 2004).

REID, M.S. Maturation and maturity indices. In: LA RUE, J.H.; JOHNSON, R.S. (Ed.) Peaches, plums and nectarines: growing and handling for fresh market. Davis: University of California, Department of Agriculture and Natural Resources, 1992. p. 21-28 (Publication, 3331).

RHODES, M. J. C. The maturation and ripening of fruits. In: THIMANN K.V.; ADELMAN R. C.; ROTH G.S. Senescence in plants. Boca Raton: CRC, 1980.p. $157-203$. 
SATO, G. S. Produção de pêssegos de mesa e para indústria no Brasil. Informações Econômicas, SP, v.31, n. 6, p. 61-63, 2001.

SCHULTE, N, L.; TIMM, E. J.; BROWN, G. K. "Redhaven" peach impact damage thresholds. HortScience, v. 29, n. 9, p.1052-1055, 1994.

SCHULTE-PASON, N.L.; BROWN, G. K. Apple, peach and pear impact damage thresholds. St. Joseph: ASAE, 1988 (ASAE Paper 90-6002).

SIMS, E.T.; COMIN, D. Evaluation of objective maturity indices for "Halehaven" peaches. Proceedings of the American Society for Horticultural Science, v.82, p. 125-130, 1963.

STEMBRIDGE， G.E.; BAUMGARDNER， R.A.; JOHNSTON， W.E.; BLARICOM, L.O.V. Measuring uniformity of peach maturity. HortScience, v. 7, p. 387-389, 1972.

ZAGORY, D. Effects of post-processing handling and packaging on microbial populations. Postharvest Biology and Technology, v. 15, p. 313-321, 1999. 